\title{
ACBAR \\ DIRECTORY OF MEMBERS \\ 1990
}

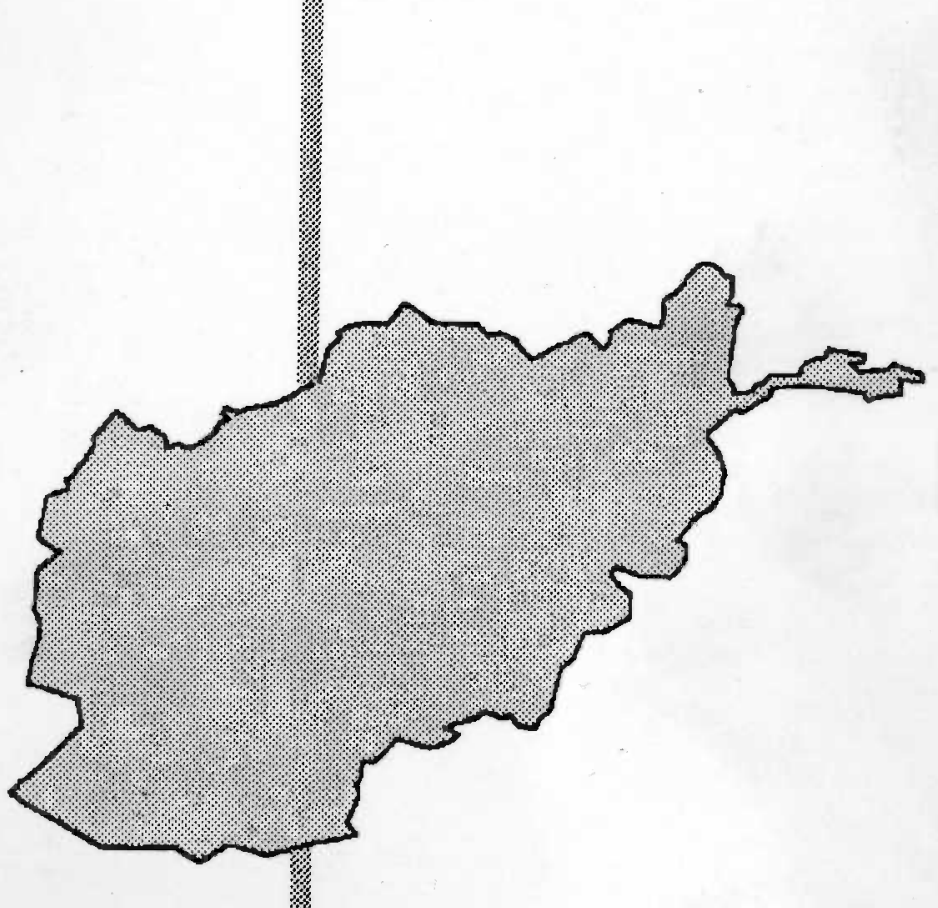




\section{ACKNOWLEDGEMENTS}

This Directory of ACBAR members was produced by a small team in close cooperation with our members. It is impossible to mention all those who contributed - in Peshawar, Quetta and Islamabad. In general terms we thank all members for spending their time in providing
us with information.

Special thanks goes to Nadette Foley for issuing the first draft under the direction of Willem Homan in the latter part of 1989; to Annette Hatting whose persistence made it possible to publish this most updated version; to Mary Anne Sennett who wrote the narratives based on the information from the members; to Masoud Safi who entered the data; to Maureen van der Vaart for designing the symbols.

We want to mention one person in particular: David Shannon (World Health Organization), who created both the ACBAR NGO Regional Coordination Database and the Database used in creating the profiles for this Directory, utilizing R-Base software. Without his irreplaceable assistance we could not have issued this and future directories.

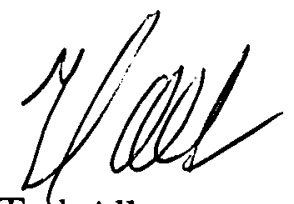

Ted Albers

Executive Coordinator
Hans Kuitert

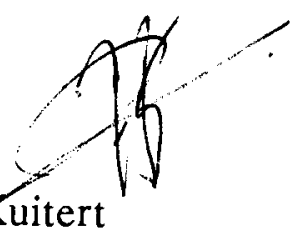

Communications Coordinator 


\section{INDEX}

Introduction

statistical summary

Guidelines (key to symbols)

\section{THE AGENCIES}

Action Internationale Medicale Estudiante (AME) ) 2

Afghan Aid Association (AAA)

Afghan Medical Aid (AMA)

Afghan Obstetrics and Gynaecology Hospital (AOGH)

Afghan Relief Foundation (ARF)

Afghan Welfare Centre (AWC)

Afghanaid

Afghanistan Nothilfe (ANH)

Afghanistan Vaccination/Immunisation Centre - AVICEN

Afghans' Health and Social Assistance Organization

AFRANE

Aide de Medicale Internationale (AMI)

The Asia Foundation (AF)

Austrian Relief Committee for Afghan Refugees (ARC) 26

Care International (CI)

Catholic Relief Services (CRS)

Council for International Development - Mercy Fund (CID)

Danish Committee for Aid to Afghan Refugees (DACAAR)

Dental Clinic for Afghan Refugees (DCAR)

Domestic Energy Saving Project (DESP)

Dutch Committee for Afghanistan (DCA)

Experiment in International Living (EIL)

Freedom Medicine (FM)

German Afghanistan Committee (GAC)

German Afghanistan Foundation (GAF)

Handicap International (HI)

HELP

Help the Afghans Foundation (HAF)

Human Concern International (HCI)

Inter-Church Aid (ICA)

International Medical Corps (IMC)

International Rescue Committee (IRC)

Islamic Relief Agency (ISRA)

Japan Afghan Medical Services (JAMS) 
Medecins sans Frontieres France (MSF-F) 78

Mercy Corps International (MCI) $\quad 80$

Norwegian Committee for Afghanistan (NCA) 82

Norwegian Church Aid/Norwegian Refugee Council(NCA/NRC) 84

Ockenden Venture (OV) 86

OXFAM

Psychiatry Centre for Afghan' (PCA)

88

Salvation Army (SA)

90

istan Appeal (SGAA)

Sandy Gall Afghanistan Appeal (SGAA) 94

Save the Children Federation - USA (SCF-US) 96

Save the Children Fund - UK (SCF-UK) 98

Serving Emergency Relief Vocational Enterprises (SERVE) 100

Shelter Now International (SNI) 102

Solidarite Afghanistan Belgium - MTA 104

Solidarites Afghanistan - Guilde du Raid (SA-GR) 106

SOS/PG Belgium - Solidarite Afghanistan Belgium 108

Swedish Committee for Afghanistan 110

University of Nebraska (UNO) 112

Veterinaires Sans Frontieres (VSF) 114

Volunteers in Technical Assistance (VITA) 116

$\begin{array}{ll}\text { World Vision (WV) } & 118\end{array}$

\section{ACBAR/SWABAC}

Agency Coordinating Body for Afghan Relief (ACBAR) 122

ACBAR Resource and Information Centre (ARIC) 124

Southern/Western Afghanistan and Baluchistan Association

for Coordination (SWABAC)

\section{ABBREVIATIONS}




\section{INTRODUCTION}

This ACBAR Directory of Members 1990 is the revised edition of the ACBAR Directory of Members published in the Fall of 1989. The sole purpose for this revision was - through making necessary corrections and refining the information - to make the Directory a more utilizable tool. Additionally, in the process of revising, there were many opportunities to update information as well.

The data on the profile pages, the descriptions of the agencies and their programs, and the information in the appendices are the responsibility of the concerned members. Any inconsistencies in the uniformity of the entries is due to the responsibility members took in developing their respective narratives and/or in the selection of data they agreed to submit; for example, some gave highly detailed information while others showed their reluctance to provide budget figures. Wherever possible ACBAR checked the data; however, it was beyond our capacity to audit the information in the directory.

Narratives were received in various stages of development: many came to us in a length, style, and grammatical form that needed little or no editing. Others arrived, either far too lengthy to meet space requirements, or quite abbreviated. Where length was at issue, editorial judgments were made that considered content over form. In some cases, the information was difficult to interpret, translate, and reconstruct, and, inevitably there have been misinterpretations; we apologize for these if and when they have occurred.

Of the NGOs based in Quetta, only those SWABAC members who are also ACBAR members, and the Southern and Western Afghanistan and Baluchistan Association for Coordination itself submitted information.

This Directory should prove a valuable resource for the many organizations involved in Afghan relief: ACBAR members, UN agencies, bilateral and multilateral donors and interested individuals in and outside the relief community.

ACBAR

March 1990 
BUDGET TOTALS OF ACBAR MEMBERS IN MILLIONS OF US \$

\begin{tabular}{lrrrr} 
& Members & $\underline{1988}$ & $\underline{1989}$ & $\underline{1990}$ \\
European Countries & 33 & 35.910 & 53.263 & 66.781 \\
Northern America & 14 & 33.681 & 48.309 & 44.785 \\
Other Countries & 12 & 10.736 & 10.291 & 6.056 \\
$\quad$ subtotals & 59 & $\mathbf{8 0 . 3 2 7}$ & 111.862 & 117.622 \\
Interfunding (minus) & & 4.600 & 9.678 & 10.482 \\
\multicolumn{1}{c}{ totals } & 59 & $\mathbf{7 5 . 7 2 7}$ & 102.184 & 107.140
\end{tabular}

BREARDOWN OF MEMBER BUDGETS BY COUNTRY IN MILLIONS OF US \$

Members Budget 1988 Budget 1989 Budget 1990

EUROPE :

\begin{tabular}{lccrr} 
Austria & 1 & 2.092 & 1.762 & 2.805 \\
Belgium & $3 \star$ & 1.114 & 1.538 & 1.292 \\
Denmark & 1 & 2.532 & 4.271 & 4.099 \\
FRG & 5 & 4.633 & 5.099 & 6.794 \\
France & 10 & 4.511 & 8.749 & 15.873 \\
Netherlands & $3 \star$ & 1.141 & 1.294 & 1.561 \\
Norway & 2 & 5.104 & 5.976 & 7.549 \\
United Kingdom & 7 & 7.214 & 13.164 & 12.035 \\
Sweden & 1 & 7.569 & 11.410 & 14.773 \\
\multicolumn{1}{r}{ totals } & 33 & 35.910 & 53.263 & 66.781
\end{tabular}

NORTHERN AMERICA:

$\begin{array}{lrrrr}\text { Canada } & 1 & 0.821 & 1.343 & \text { unknown } \\ \text { USA } & 13 & 32.860 & 47.046 & 44.785 \\ & 14 & 33.681 & 48.389 & 44.785\end{array}$

OTHER COUNTRIES :

\begin{tabular}{lllll} 
Afghan NGOs & $8 * \star$ & 1.330 & 2.075 & 1.590 \\
Australia & 1 & 2.208 & 1.435 & 1.683 \\
Japan & 1 & 0.040 & 0.073 & 0.093 \\
Sudan & 1 & 5.771 & 5.484 & 1.793 \\
Pakistan & 1 & 1.387 & 1.224 & 0.897 \\
\multicolumn{1}{r}{ totals } & 12 & 10.736 & 10.291 & 6.056
\end{tabular}

* MSF Netherlands and Belgium run a combined program.

* * Another 4 Afghan-run NGOs have applied for membership

NOTE: The budgets are submitted by member agencies. Amounts include interfunding by member agencies. 


Pakistan
only

European Countries Northern America other Countries totals

\section{Afghanistan only}

5
2
-

7
In Both countries

ACBAR MEMBERS PROGRAMS IN PAKIBTAN AND AFGHANISTAN IN MILLIONS OF US DOLLARS

Pakistan

$$
1988
$$

1990

1988

Afghanistan

18

9

8

35

\begin{tabular}{lrrrrrr} 
Europe & 18.375 & 20.059 & 27.646 & 17.555 & 32.816 & 38.611 \\
N.Amerca & 9.775 & 9.987 & 11.076 & 23.950 & 38.389 & 35.926 \\
Others & 10.360 & 8.524 & 4.435 & 0.409 & 1.764 & 1.567 \\
\multicolumn{1}{c}{ totals } & $\mathbf{3 8 . 5 1 0}$ & $\mathbf{3 8 . 5 7 0}$ & $\mathbf{4 3 . 1 5 7}$ & $\mathbf{4 1 . 9 1 4}$ & $\mathbf{7 2 . 9 6 9}$ & $\mathbf{7 6 . 1 0 4}$
\end{tabular}

ACBAR MEMBERS AS EMPLOYER

International personnel Afghan personnel

Pakistan personnel

totals

$$
1988
$$

1989

1990

$$
210
$$

3,531

697

4,438

340

5,970

1,010

6,356

838

7.320

7,551 
In the listing on this page the symbols are explained, which are used in this Directory.

The symbols are printed on the profile-page. Each agency has its own profile.

The order in the address fields is:

1. mailing address;

2. street address;

3. telephone

4. telex;

5. fax;

6. name director or representative;

7. names of other contacts.

The same system is used in the print fields for suboffices and headquarters.

In the name field of the agency on the top of the page, the right corner indicates whether an agency is a member of ACBAR, SWABAC, ACBAR and SWABAC or an Associate member.

Zero's (0) on the profile pages can also mean that the information on the budget was not available.

Under Funders only a general indication is used: UN-agencies, Governments, Private funding.

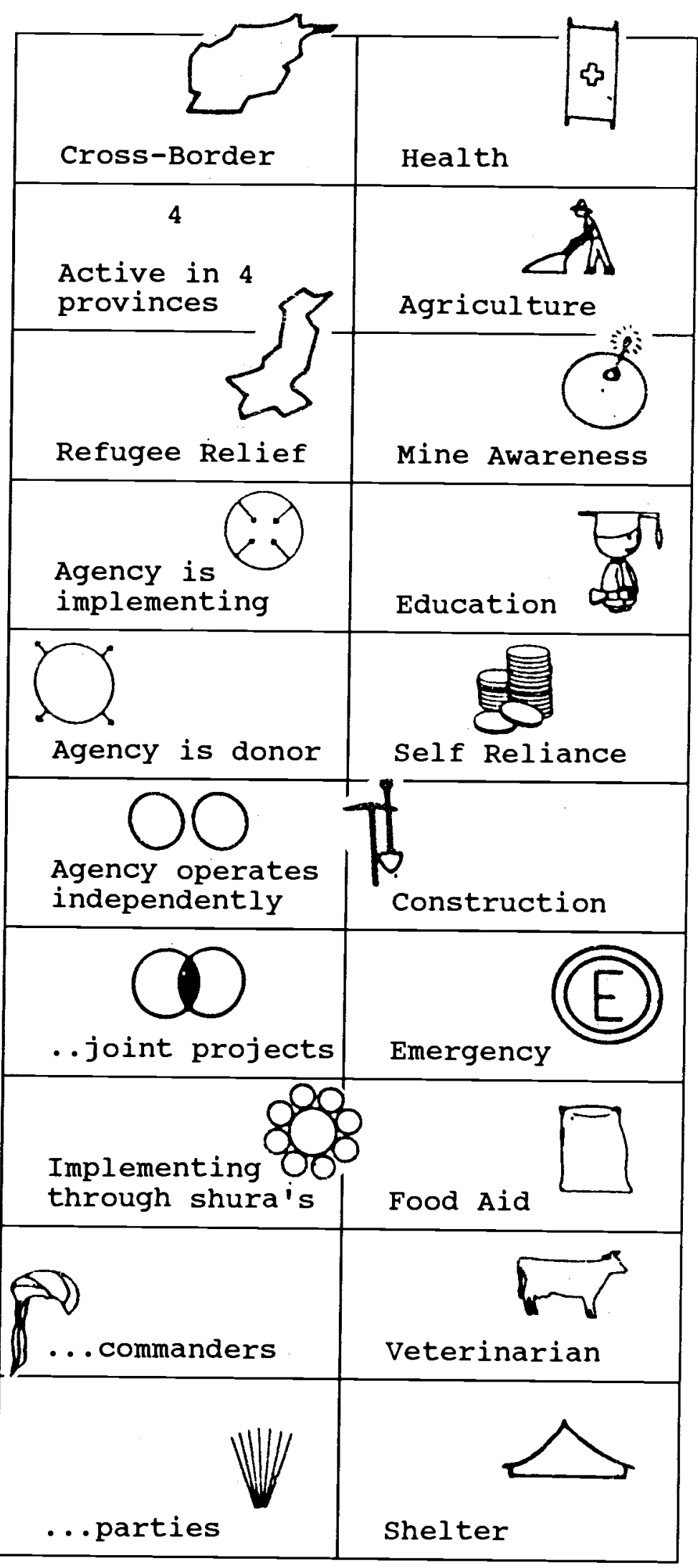




\section{THE AGENCIES}




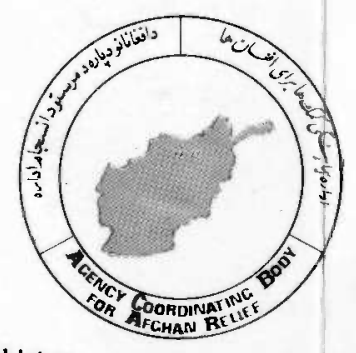

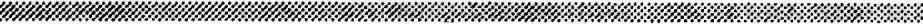

Tel. $-/ 92.521 .40 .389$

Fax:--/92.521.42.471 
LOCAL ADDRESS

UNIV P O BOX 887, PESHAWAR

C/O SHAH JAHAN

77 D A/B PARK ROAD, UNIV TOWN PESHAWAR

TEL : 42245

TLX: 880400 F(CODET 31117)

FAX: 42429

MR. SHAH JAHAN (REPRESENTATIVE)

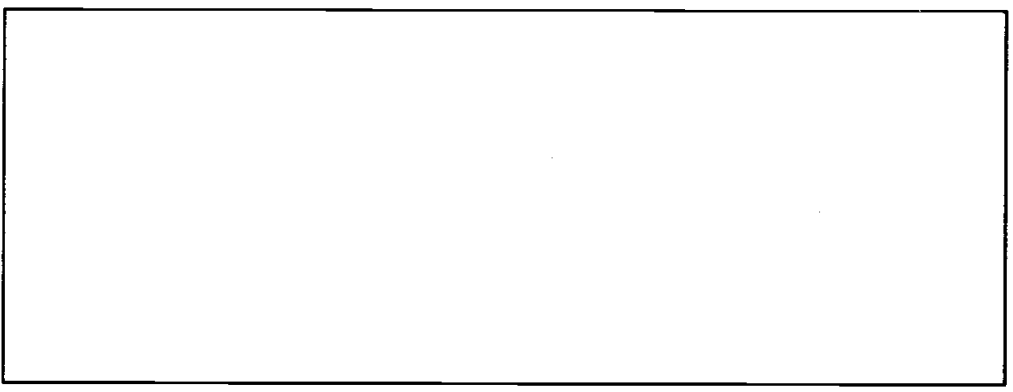

HEADQUARTERS

GABRIELLE GOETZ

A.I.M.E., 5 PETITE RUE

D'AUSTERLITZ 67000 STRASBOURG, FRANCE TEL: $88 \quad 37 \quad 11 \quad 58$

FAX:

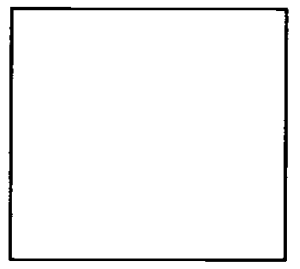

๑. 


\section{ACTION INTERNATIONALE MEDICALE ESTUDIANTE}

did not submit any information

NOTE: the data on profile page could not be checked 


\section{LOCAL ADDRESS}

UNIV P O BOX 954

PESHAWAR, PAK

JAMAL ROAD, STREET NO 5

SHAHEEN TOWN PESHAWAR, PAK

TEL: C/O 42987

TXL:

FAX:

DR. SAADAT SHAGIWAL (DIRECTOR)

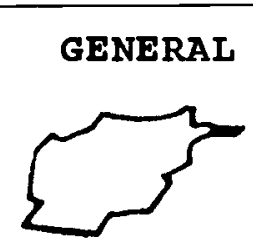

$\bigcirc \bigcirc$

PESHAWAR, PAK

TEL: C/O 42987

TXL:

FAX:

\section{HEADQUARTERS}

DR. SAADAT SHAGIWAL

UNIV P O BOX 954

\begin{tabular}{|lrr|}
\hline \multicolumn{3}{|c|}{ PERSONNEL } \\
EXPATS & 0 & $0 \%$ \\
AFGHANS & 28 & $100 \%$ \\
PAKISTANIS & 0 & $0 \%$ \\
TOTAL & 28 & \\
\hline
\end{tabular}

\begin{tabular}{|ll}
\hline BUDGET (US \$) & 1987 \\
AFGHANISTAN & 40,509 \\
PAKISTAN & 52,080 \\
TOTAL & 92,992
\end{tabular}

\section{FUNDERS}

UN
4
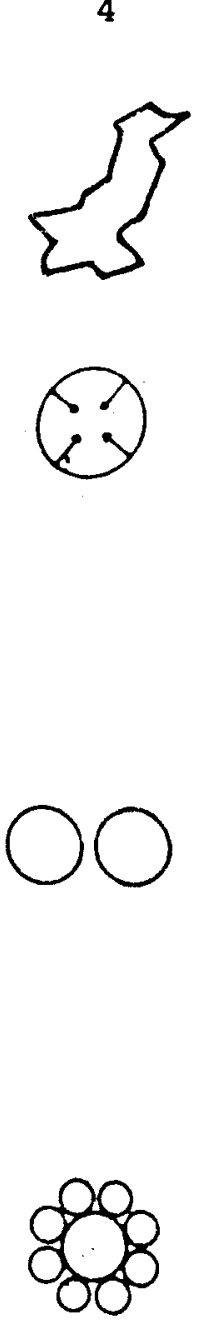

SECTOR
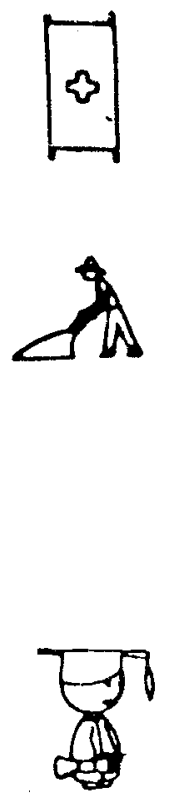

n
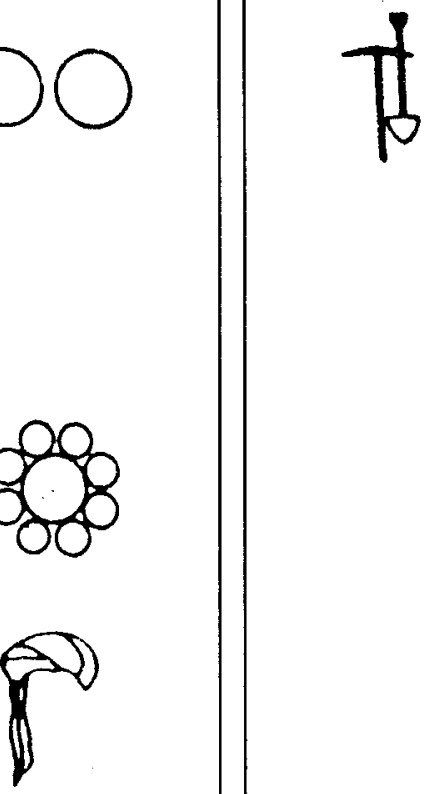
The AFGHAN AID ASSOCIATION

(AAA) was founded in 1983. It works in both the health and agricultural sectors. AAA also intends to implement a rehabilitation and reconstruction program.

In 1987, the Association opened a clinic in Peshawar which provides medical treatment to between 4,500 and 5,000 men, women and children each month. AAA is also conducting a male training program; one course is for a three-month period, another for six months. Four clinics have been set up in Afghanistan in the following provinces: Laghman, Parwan, Jozjan and Nangarhar.

AAA is looking for foreign volunteers (doctors, nurses, medical assistants, etc.) to come for short periods of time to work inside Afghanistan. The organization would also welcome consultants who could assist it in its administration and proposal preparation.

In the agricultural sector, a number of projects are underway: a stream project was initiated in October; a survey is being conducted in Nangarhar and Laghman Provinces with regard to road construction, housing, irrigation and other agricultural needs. In Nangarhar (Khugiyani District, Sherzad sub-district) work has already started.

Funding: UNHCR, WHO and others. 


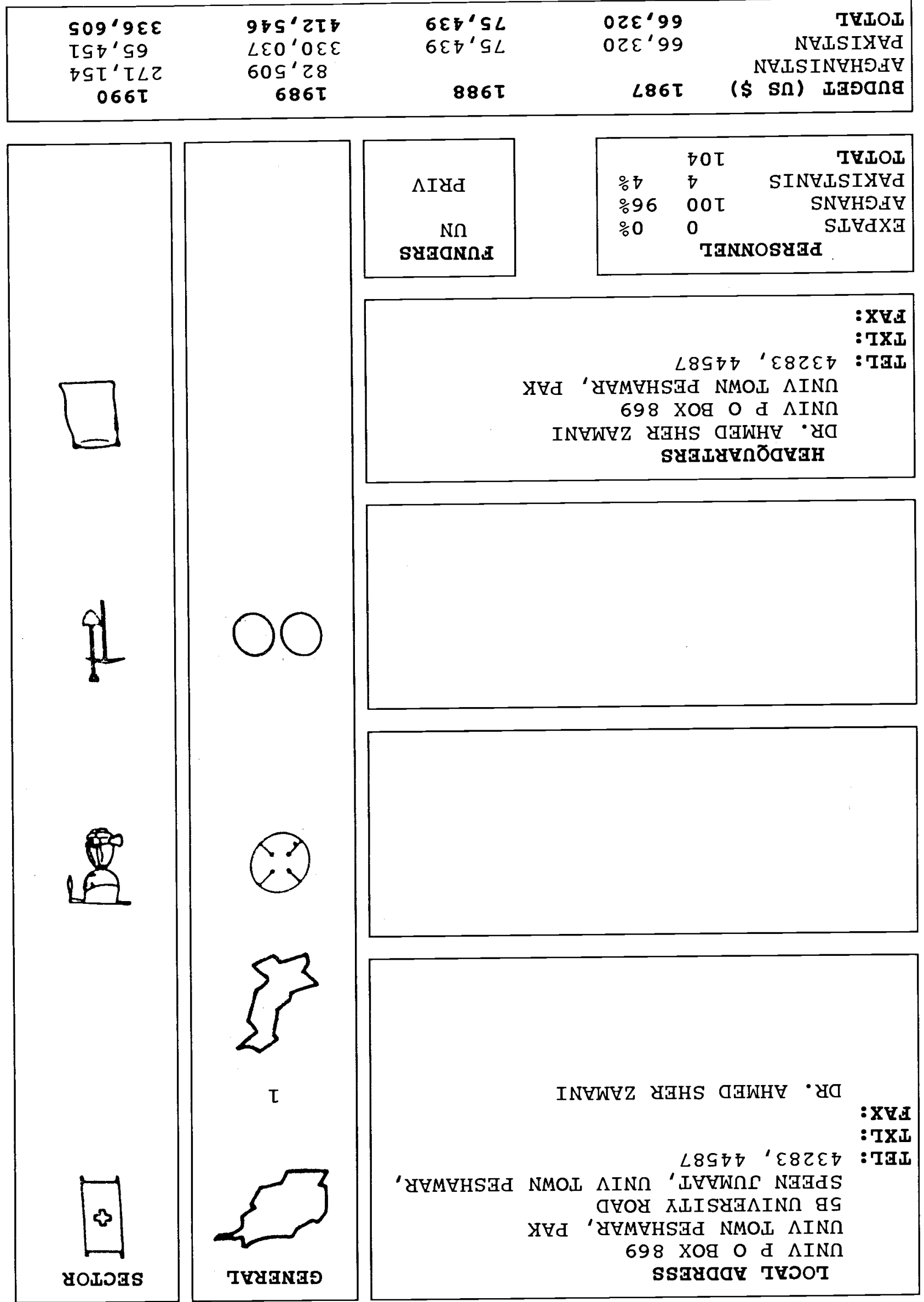


AFGHAN MEDICAL AID (AMA) was established in November of 1983 in Peshawar. AMA works both in the refugee camps in Pakistan and in Afghanistan. Their principal health care facility is a clinic in Peshawar. Two Basic Health Units are operated in Bajaur Agency-Ganjgal and Rashakai, out of which AMA provides a milk distribution service for children as well as vaccination and Traditional Birth Attendant programs.

The main clinic in Peshawar provides for ante- and post-natal care and treatment for the following diseases: eye and ear infections, respiratory tract infections, joint and skin diseases, nervous disorders, parasitic problems and disorders of the intestinal tract. An estimated 25,000 patients are treated at the clinic annually. Additionally, the clinic is currently training 20 Afghan students for FHA.

In Afghanistan, primarily in Kunar, Afghan Medical Aid is active in the training of dais. This program was started in April 1989, in Pech valley. A second was started in Narang sub-district in November 1989 by a mobile team, which will train 40 dais in a three-month period.

In central Nuristan and Dehves Valley, in an area covering 25 villages with a population of approximately 10,000 people, a paramedic programme is operating. AMA has extended its malaria control program in central Nuristan to nine villages--Keygal, Chimie, Vant, Mundesh, Gemamash, Waygal, Shinigal and Kurbagh.

AMA has one primary school in Ganjgal camp and another in Ganjgal village in Kunar province. The number of students in Ganjgal primary school is 100 and in Ganjgal, Kunar, it is 107.

Repair work on Asadabad hospital was started in July 1989, was finished in August
1989, and handed over to a central council of mujahedien. Another reconstruction project in Afghanistan has been the repair of the Sarkani and Khas Kunar road.
Funding: Afghan Relief (U.K.), Oxf a m, Overseas Development Agency, UNHCR, and UNICEF. 
LOCAL ADDRESS

G P O BOX 448

PESHAWAR, PAK

2 CIRCULAR ROAD

UNIV TOWN PESHAWAR, PAK

TEL: 40721

TXL:

FAX:

M. HUSSAIN MOMAND, M.D. (DIRECTOR) MS. JILL HOFFMAN, P.A.
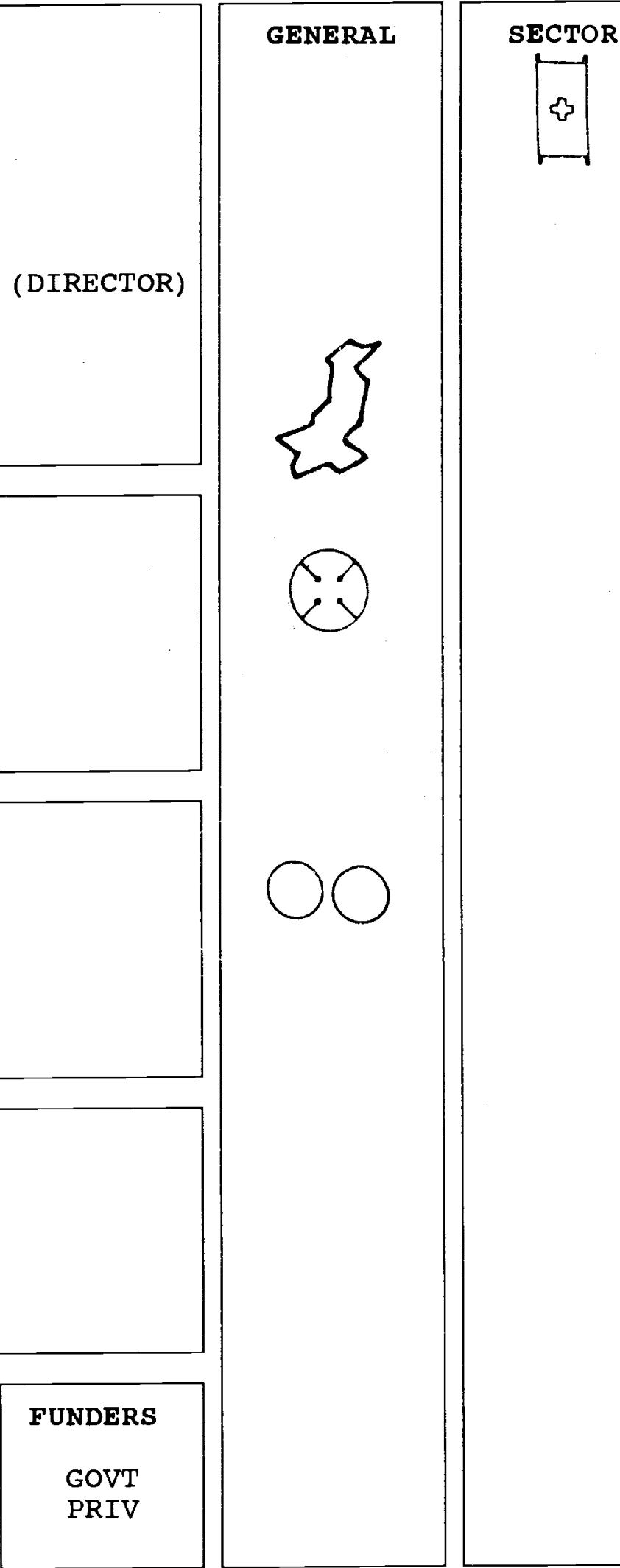

M. HUSSAIN MOMAND, M.D.

$G P$ O BOX 448

TEL: 40721

PESHAWAR, PAK

TXL:

FAX :

\begin{tabular}{|lrr|}
\hline \multicolumn{2}{|c|}{ PERSONNEL } \\
EXPATS & 3 & $3 \%$ \\
AFGHANS & 80 & $90 \%$ \\
PAKISTANIS & 5 & $5 \%$ \\
TOTAL & 88 & \\
\hline
\end{tabular}




\section{THE AFGHAN OBSTETRICS} GYNAECOLOGY HOSPITAL (AOGH) was founded in 1984 with the support of the International Rescue Committee, to provide improved obstetric and gynaecologic facilities to Afghan women.

Sixty percent of the Afghan refugee population consists of women and children. The harshness of life in the camps contributes to malnutrition, anaemia and disease which create a difficult climate for women of child bearing age. Since at any given time an estimated $40 \%$ of the women, aged between 16 and 45 , are pregnant, the provision of obstetric and gynaecologic facilities is an essential element of any attempt to assist Afghan women.

The hospital began as an outpatient unit, and a five-bed inpatient facility and labour room were added later. It now has a surgical unit and an air-conditioned 15 -bed inpatient unit. During 1987 with the help of a Pakistani pediatrician, facilities for paediatric care, particularly of preterm infants, were developed, enabling the hospital staff to save the life of a 28-week old infant who had been refused admission to a local hospital due to its size and non-viability of space. After 51 days of careful treatment the baby was discharged in good condition.

A team of Afghan doctors and nurses is assisted by visiting expatriate medical staff. Some of the staff operate a mobile obstetrics and gynaecology service for the camps. Over the years, the numbers of women coming for ante-natal care with the intention of delivering their babies in the hospital has greatly increased. More women are also seeking advice on birth control, and there has been a tremendous response to the immunization service.
Funding: Help (Germany), Help the Afghans Foundation, the Norwegian Refugee Council, Doctors for Afghanistan, the Governments of Australia, New Zealand and Japan and groups in the USA and France. 
LOCAL ADDRESS

G P O BOX 1215

POST CODE 25000 PESHAWAR, PAK 17-F/1 K K KHATTAK ROAD

UNIV TOWN PESHAWAR, PAK

TEL: 42214

TXL:

FAX :

MR. SYED ISHAQ GAILANI (DIRECTOR)

MR. ABDUL HAQ

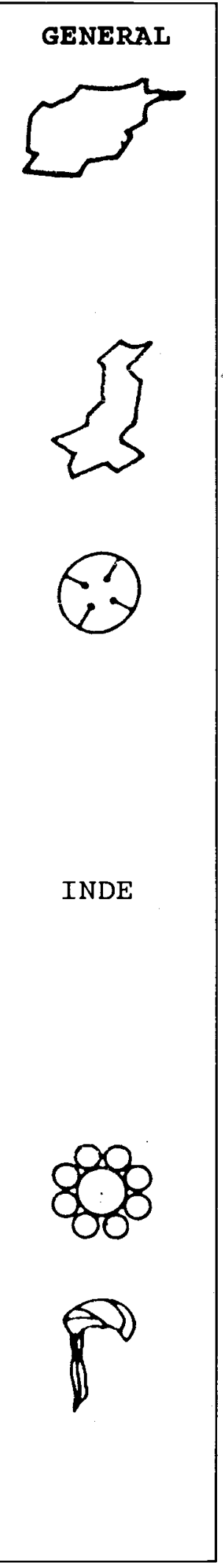

\section{HEADQUARTERS}

MR. SYED ISHAQ GAILANI

G P O BOX 1215

POST CODE 25000 PESHAWAR, PAK

TEL: 42214

TXL:

FAX:

\begin{tabular}{|lrr|}
\hline \multicolumn{3}{|c|}{ PERSONNEL } \\
EXPATS & 0 & $0 \%$ \\
AFGHANS & 7 & $88 \%$ \\
PAKISTANIS & 1 & $12 \%$ \\
TOTAL & 8 & \\
\hline
\end{tabular}

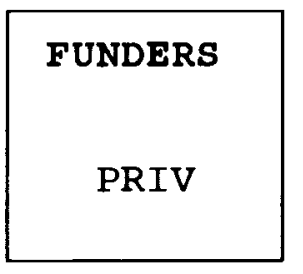

$$
10
$$

\section{7}

115,740

79,861

195,601

\section{8}

110,987

79,861

155,937

\section{9}

146,941

41,625

188,539
SECTOR
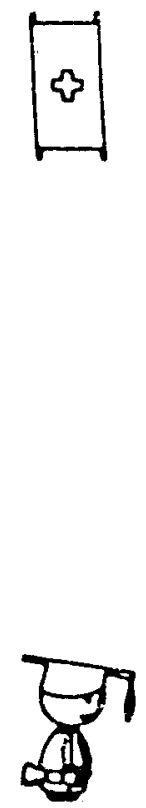
An Afghan run non-governmental organization, the AFGHAN RELIEF FOUNDATION (ARF) was founded in 1986 with the support of Help the Afghans Foundation (the Netherlands).

Afghan Relief Foundation started its relief work for the destitute people of Afghanistan by providing food commodities like wheat, rice, edible oil, tea, soup, etc. Later on the Foundation established a mother and child health care clinic.

The Mother and Child Health Care Clinic is run by three doctors, five nurses and 14 other staff persons. In this clinic, situated in Shaheen Town, Peshawar, about 100 to 150 out-patients per day come for consultation and treatment.

Afghan Relief Foundation has also established two schools, one in Munda Refugee Camp and another in the Khyber pass area, the Sultan Mahmood Ghaznavi Vocational School and Khyber Agency School, respectively; about 1000 students receive their education in these schools. Most of the students are orphans who also receive a monthly allowance of Rps. 200 to help support them.

In Afghanistan, ARF has provided emergency aid in various provinces. In all cases food commodities and used clothes were distributed among the destitute. All programs have taken place under the supervision of a representative of this office at all times and with the help and full cooperation of commanders and the chiefs of the tribes.
Funding: Help the Afghans Foundation ( The Netherlands). 


\section{LOCAL ADDRESS}

UNIV P O BOX 791

UNIV TOWN PESHAWAR, PAK

STREET NO 4

NASIR BAGH ROAD PESHAWAR, PAK

TEL: 42851

TXL:

FAX :

DR. RAHIM PASHTOON YAR (DIRECTOR)
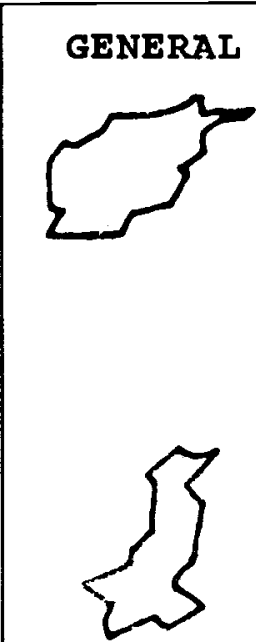

SECTOR

\section{HEADQUARTERS}

DR. RAHIM PASHTOON YAR

UNIV P O BOX 791

UNIV TOWN PESHAWAR, PAK

TEL: 42851

TXL :

FAX :
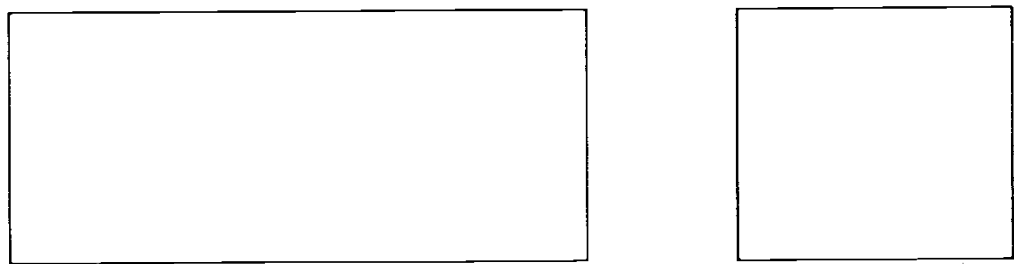

PAKISTAN

TOTAL 


\section{AFGHAN WELFARE CENTRE}

did not submit any information

NOTE: the data on profile page could not be checked 


\section{LOCAL ADDRES 8}

5B GULMOHAR ROAD

UNIV TOWN PESHAWAR, PAK

5B GULMOHAR ROAD

UNIV TOWN PESHAWAR, PAK

TEL: $42030 / 42322$

TXI:

FAX: 8378155

MR. PETER REES (FIELD DIRECTOR)

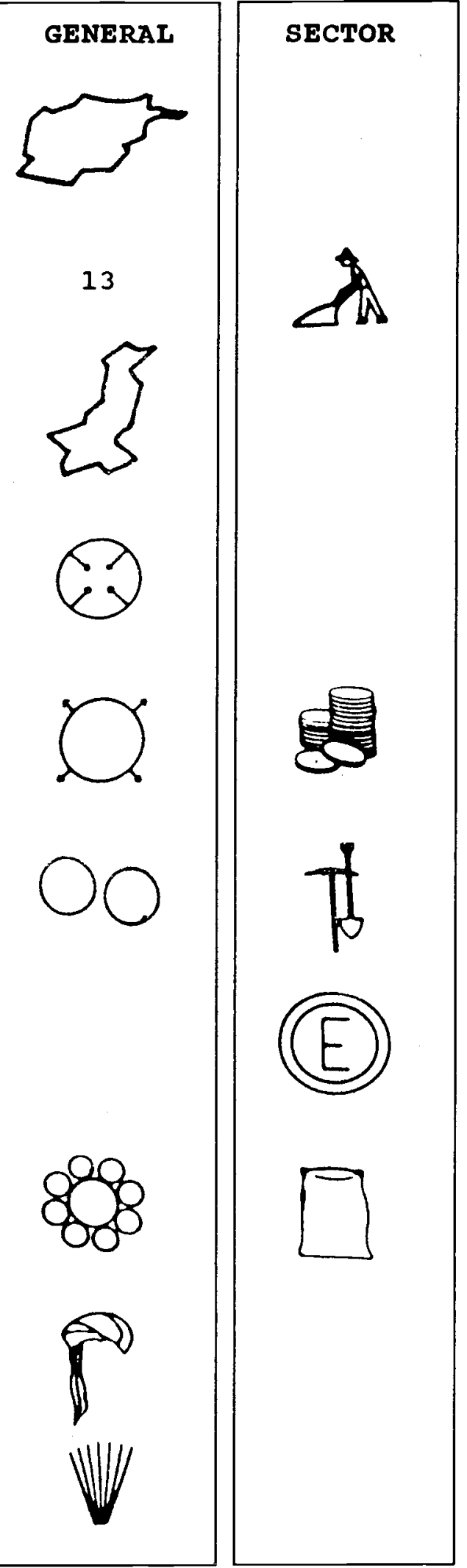

HEADQUARTERB

MS. JACKIE WRAY

290/292 PENTONVILLE ROAD

LONDON NI 9NR, ENGLAND

TEL: $\begin{array}{lllll}44 & 1 & 278 & 2832\end{array}$

TXL:

FAX:

\begin{tabular}{|lrr|}
\hline \multicolumn{3}{|c|}{ PERSONNEL } \\
EXPATS & 9 & $9 \%$ \\
AFGHANS & 85 & $85 \%$ \\
PAKISTANIS & 5 & $5 \%$ \\
TOTAL & 99 & \\
\hline
\end{tabular}

\begin{tabular}{|l|}
\hline FUNDERS \\
UN \\
GOVT \\
PRIV \\
BILAT \\
\hline
\end{tabular}

SECTOR

\begin{tabular}{|lcrrr|}
\hline BUDGET (US \$) & 1987 & 1988 & 1989 & 1990 \\
AFGHANISTAN & $1,776,620$ & $3,607,103$ & $8,379,578$ & $4,409,078$ \\
PAKISTAN & 202,254 & 188,679 & 221,975 & 187,003 \\
TOTAL & $1,978,874$ & $3,745,782$ & $8,601,553$ & $4,675,081$ \\
\hline
\end{tabular}


AFGHANAID was set up in 1984 and now runs cross-border agricultural rehabilitation projects, a tailoring program for disabled refugee tailors, emergency programs including food distribution, and an ambulance service.

The tailoring project in the camps provides employment for 70 disabled tailors who make school uniforms for refugee children. Since 1986 AFGHANAID has been running an ambulance service evacuating warwounded from front-line areas. At present seven ambulances are being operated, five for Jalalabad and two for Khost/Gardez.

The main area of work is in Afghanistan implementing agricultural rehabilitation programmes. All programs consist of the same basic elements of irrigation repair, inputs of seed and fertilizer and assistance with traction. AFGHANAID presently runs agricultural programmes in 13 provinces, concentrated mainly in the north of Afghanistan. By October 1989, AFGHANAID had taken a total of 790 tons of improved seed and fertilizer across the border, and 160 pairs of oxen had been transported to project areas. AFGHANAID also runs pilot projects in opium eradication and house reconstruction.

In addition to agricultural programs, AFGHANAID will respond to emergency situations and have, in the past, provided assistance to Badakshan to help alleviate the food shortage and to the people of the Salang after a bombing attack destroyed their homes and agriculture. AFGHANAID is also running food distribution programs to vulnerable groups in areas around Kabul and plans to provide food to the people in the northwest of Afghanistan affected by the locust and sunnpest infestation.

AFGHANAID has a field staff of 38 persons who, in cooperation with the local populace, survey the project areas, assess needs and implement the programs. Local leaders and elders are consulted at the regional and village level, and people are elected from the community to work with the AFGHANAID staff in implementing and administering the program. Programs are also monitored by expatriates.

The rehabilitation project at Robart, Ghazni, focuses on allowing an internally displaced population to return home by providing assistance to revive food production. The irrigation system was surveyed in March and work on twelve karez commenced in August, 1989. Inputs of 35 tons of winter wheat, 20 tons of short-season spring wheat and 100 tons of fertilizer have been provided by FAO. The seed is treated in the area in treatment drums transported from Peshawar. Fortyfour pairs of oxen have also been distributed. It is estimated that this project will produce 935 tons of wheat in 1990.

Funding: Overseas Development Agency (ODA), USAID, UNHCR, UNDP, WFP, FAO, Canada and Help the Afghans Foundation. 
LOCAL ADDRESS

G P O BOX 679

PESHAWAR, PAK

HOUSE \#17-E JAHANGIRABAD

UNIV TOWN PESHAWAR, PAK

TEL: $42591 / 42818$

TXL: 52369 PCOPE PK

FAX:

DR. SCHREK

DR. YAR

MR. WAHIDI
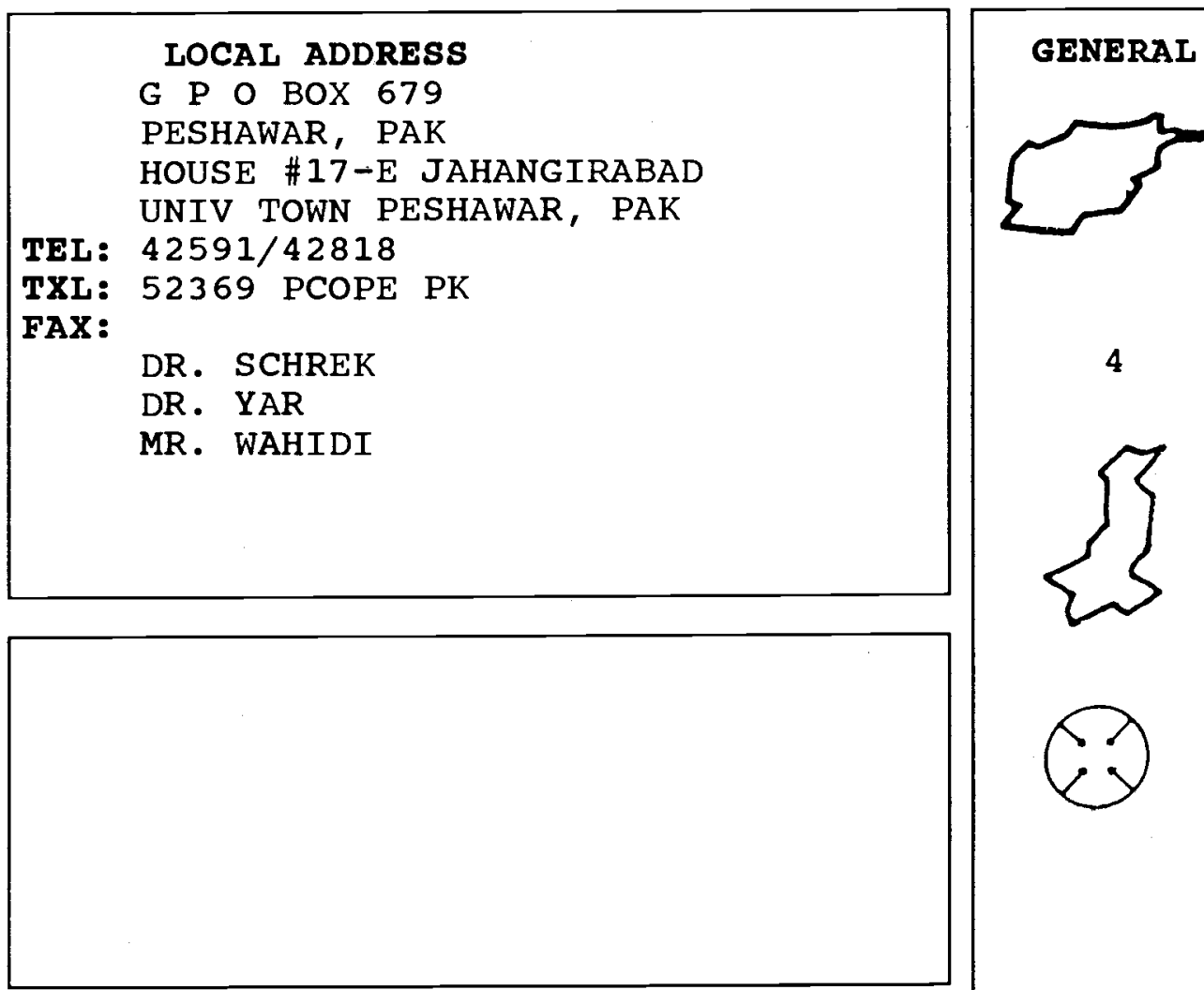

4
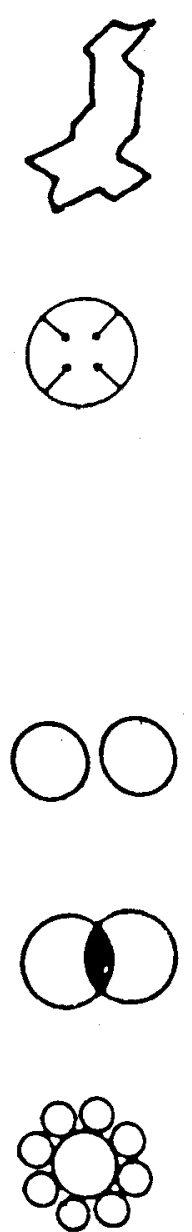

MONCHENGLADBACH-1 WEST GERMANY

TEL: $02161-208280$ OR 208960

TXL: 8529208 ANH D

FAX:

\begin{tabular}{|lrr|}
\hline \multicolumn{3}{|c|}{ PERSONNEL } \\
EXPATS & 10 & $11 \%$ \\
AFGHANS & 75 & $88 \%$ \\
PAKISTANIS & 0 & $0 \%$ \\
TOTAL & 85 & \\
\hline
\end{tabular}

FUNDERS

GOVT

PRIV
SECTOR

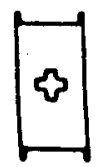

\begin{tabular}{|lcccc|}
\hline BUDGET (US \$) & 1987 & 1988 & 1989 & 1990 \\
AFGHANISTAN & 86,805 & 55,493 & 146,914 & \\
PAKISTAN & 260,416 & 277,469 & 244,857 & \\
TOTAL & 347,221 & 332,962 & 391,771 & \\
\hline
\end{tabular}


AFGHANISTAN NOTHILFE (AN) was founded in 1983 through the joint efforts of German and Afghan doctors. In 1987, AN began administering to Afghans in Pakistan and Afghanistan. Its Board of Directors consists of members of political parties and medical specialists.

Medical services and facilities of $\mathrm{AN}$ consists of: an 80-bed hospital in Peshawar, three primary health units at refugee camps in NWFP, a polyclinic with a teaching center at Quetta, and eight dispensaries in Kunar, Nangarhar, Paktia and Kandahar provinces.

The hospital at Peshawar offers surgical treatment, internal medicine, eye and dental treatment, $\mathrm{x}$-ray facilities and a laboratory. A vaccination program is run by UNHCR, a TB treatment program by ICD, milk distribution provided by SNI, and a facility for lab examination is operated by Afghanaid. Each month, approximately 150 surgical cases are admitted, and 300-350 patients receive admission in the hospital. More than 6000 are received at the polyclinic. Since December 1988, the health units have rehabilitated between 800 to 1300 patients. Since 1983, AN has sent 68 physically handicapped children to West Germany for appropriate treatment.

Through the support of CARE, a German committee, Afghanistan Nothilfe provides one- and two-year medical nursing courses, and more than 600 male and female students are now graduates. Each year the people of West Germany and their government contribute 8 to 9 million rupees and 1.5 million respectively. Since 1987, 26 German doctors and nurses have worked with Afghanistan Nothilfe.
Funding: The West German Government, donations of the West German people, and CARE, a German committee. 

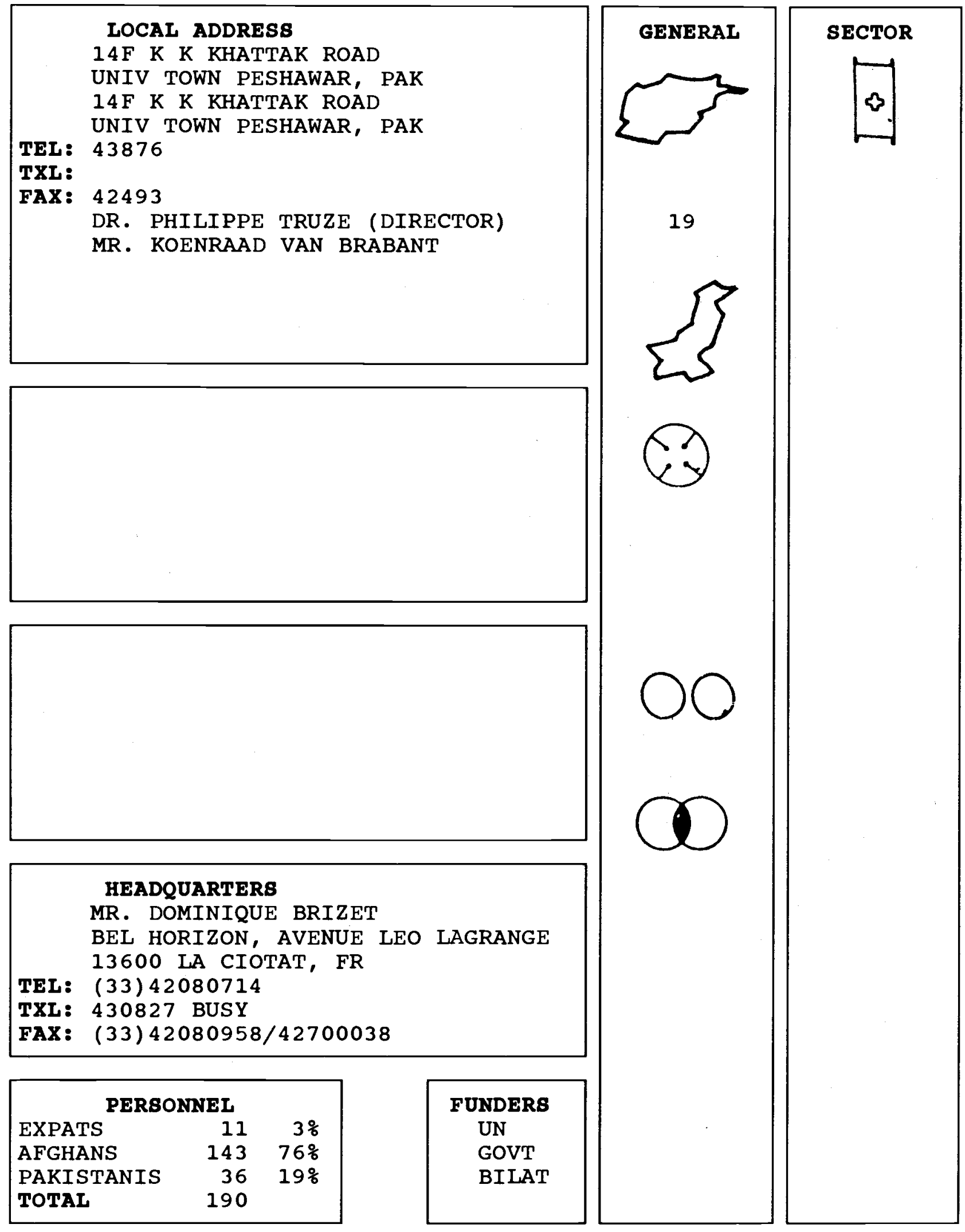

\section{HEADQUARTERS}

MR. DOMINIQUE BRIZET

BEL HORIZON, AVENUE LEO LAGRANGE 13600 LA CIOTAT, FR

TEL: (33) 42080714

TXI: 430827 BUSY

FAX: (33) $42080958 / 42700038$

\begin{tabular}{|lrr|}
\hline \multicolumn{3}{|c|}{ PERSONNEL } \\
EXPATS & 11 & $3 \%$ \\
AFGHANS & 143 & $76 \%$ \\
PAKISTANIS & 36 & $19 \%$ \\
TOTAL & 190 & \\
\hline
\end{tabular}

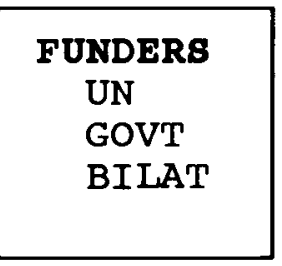

BUDGET (US \$) 1987
AFGHANISTAN
PAKISTAN
TOTAL

1988

804,661

804,661
1989

$1,616,062$

58,765

$1,674,827$
1990

$2,337,540$

52,360

$2,389,900$ 
The AFGHANISTAN VACCINATION AND IMMUNIZATION CENTER (AVICEN) in Peshawar was created in September 1987, as an infra-structural support to an existing vaccination campaign inside Afghanistan that began in 1983. AVICEN now includes a training center, a cold store with repair workshop, a unit for operations and one for research and analysis.

The purpose of the AVICEN program is to control, through immunizations, six easily-preventable diseases in Afghanistan: measles, TBC, diphtheria, polio, whooping cough (pertussis), and tetanus infections.

AVICEN has as one of its goals the establishment of an Expanded Program of Immunization (EPI) infra-structure within Afghanistan, through which it hopes to promote the development of other public health programs as well.

In addition to providing immunizations in three refugee camps in NWFP in Pakistan, AVICEN is currently implementing vaccination and immunization programs in 19 provinces in Afghanistan; by early 1990, this number will increase to 22 .

By the end of September 1989, an estimated 95.391 people were vaccinated; by the end of 1989, the Center - at its current success rate - will have vaccinated some 180.000 people inside Afghanistan.

AVICEN puts trust in and relies on Afghan staff to implement its programs. Training (of vaccinators, field trainers and supervisors) is, therefore, an essential aspect of their approach. The implementation of its program in Afghanistan and the success realized has been based on the tailoring of its activities to meet the present conditions there. AVICEN practices "an active neutrality" and works with all parties, ethnic and religious groups. It maintains relationships with the population in agreement with parties and commanders.

For 1990, AVICEN plans to improve the output per vaccinator team and reduce costs of vaccinations. Also planned are: a survey of vaccination coverage, a serological study (if funding can be found), and pilot projects in other areas of preventive medicine and public health-goitre, Vitamin A deficiency, health and hygiene training and dai training--inside Afghanistan.

Funding: French Government, European Community, UNICEF, UNDP and UNHCR. 


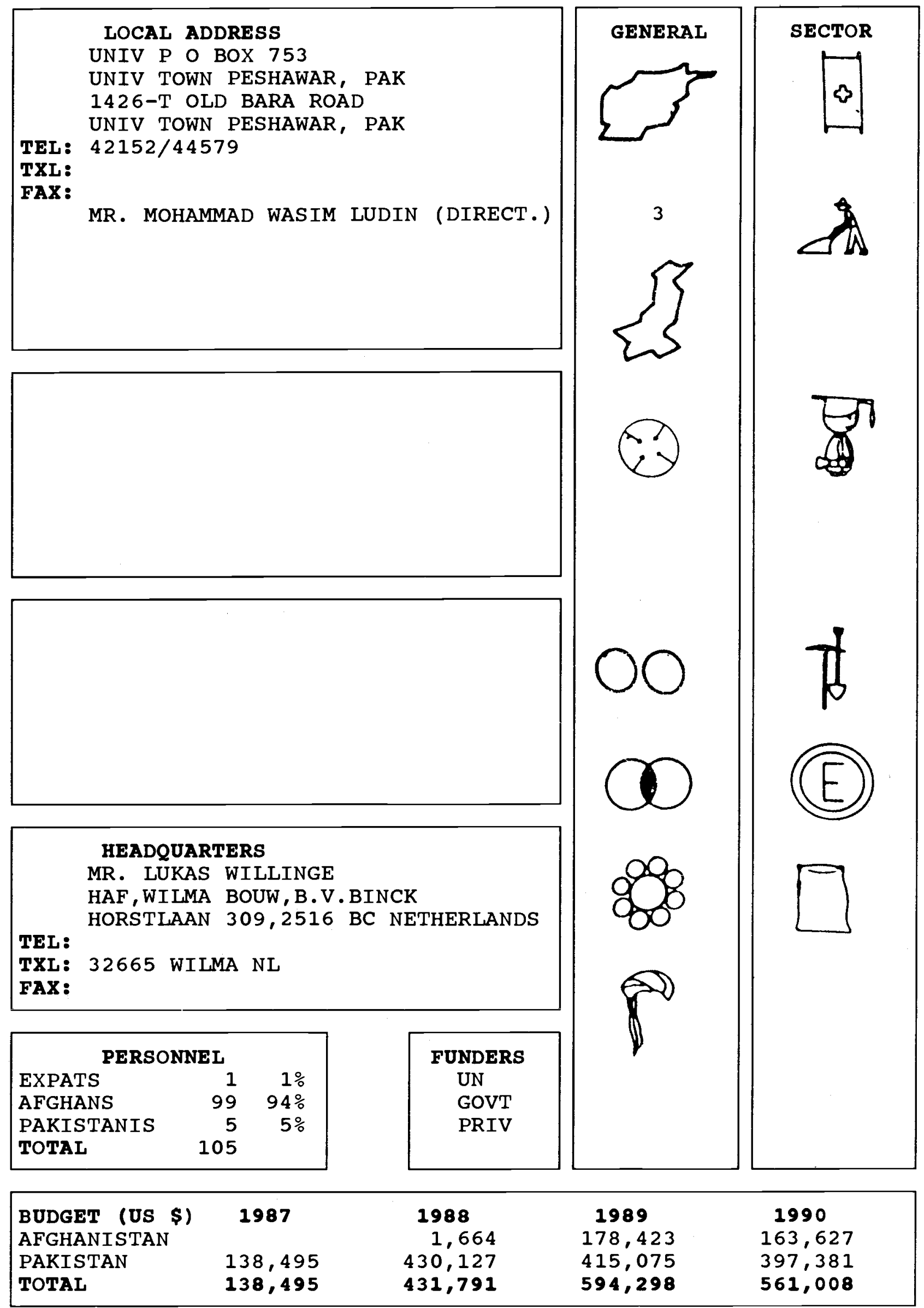


AFGHANS' HEALTH AND SOCIAL ASSISTANCE ORGANIZATION (AHSAO) was organized in June of 1985 to meet the various health and education needs of Afghan Refugees. In Peshawar, a children's clinic with an out-patient department and a 20-bed "indoor patient department" provide a broad range of services for children as well as for adults.

The out-patient department of the children's unit examines, diagnoses and treats mild to severe disorders and diseases through its following programs:

1. Malnutrition. Malnourished children are treated and. issued food of high-nutrient value (fruit, eggs, dal, high protein biscuits, etc.);

2. Special Care. For children who need continuous and/or prolonged medical care for illnesses such as polio, epilepsy, diabetes, asthma, blood problems;

3. Vaccination. Afghan children and their mothers are provided all vaccines;

4. Tuberculosis. In this department male and female adults and children suffering from T.B. are examined and treated;

5. Health Education. A health educator works with two groups of 20 women each day for 45 -minute periods, teaching hygiene, sanitation, nutrition, treatment of diarrhoea, communicable diseases.

When treatment is not possible in the outpatient department, children are admitted for extended care in the in-patient facility.

Two basic health units operate in the Aza Khel camp zone, in which between $300-$ 400 patients (male, female and children) are treated daily. The same range of health care services are offered in the
BHU's as are in the Children's Clinic. In addition there is a malaria control program and a mobile vaccination team attached to the units. Clinics are also operating in Nangarhar and Kunar Provinces.

A TBA Training Program has been recently started in Aza Khel to train 150 Afghan women. After training, these women will work in Aza Khel. Other education projects/programs include an English Language Course, two primary schools in Pakistan in Dilawar Shah and Badeber camps and one in Nuristan in Afghanistan. One-year paramedic and 6month nursing and technician training courses are provided to Afghan students.

AHSAO has two agricultural projects in Chowki and Khas Kunar Districts in Kunar Province.

Funding: Norwegian Refugee Council, Inter-Church Aid (Pakistan), Help the Afghans Foundation ( $T$ h e Netherlands), HELP (West Germany), Swedish Committee for Afghanistan UNHCR, UNICEF, World Food Programme. 
LOCAL ADDRESS

2 PARK LANE

UNIV TOWN PESHAWAR, PAK

2 PARK LANE

UNIV TOWN PESHAWAR, PAK

TEL : 42320

TXL: 52490

FAX: 42461

MS. SOPHIE JACQUIN (REPRESENTAT.)

MS. SYLVIE GALLOT
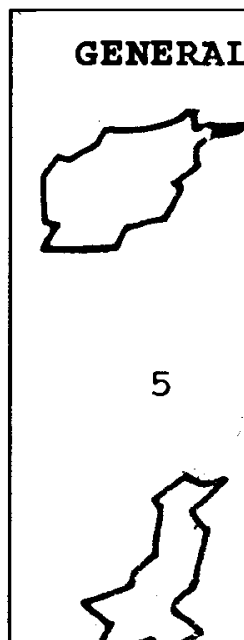

5
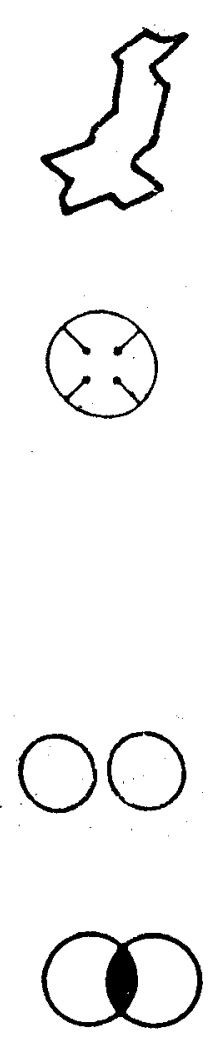

HEADQUARTERS

MR. BERNARD DUPAIGNE

8 RUE CHRISTINE

75006 PARIS FRANCE

TEL: $1 \begin{array}{lllll}1 & 43 & 26 & 04 & 14\end{array}$

TXL:

FAX: $143326 \quad 04 \quad 14$

\begin{tabular}{|lrr|}
\hline \multicolumn{3}{|c|}{ PERSONNEL } \\
EXPATS & 2 & $6 \%$ \\
AFGHANS & 30 & $88 \%$ \\
PAKISTANIS & 2 & $6 \%$ \\
TOTAL & 34 & \\
\hline
\end{tabular}
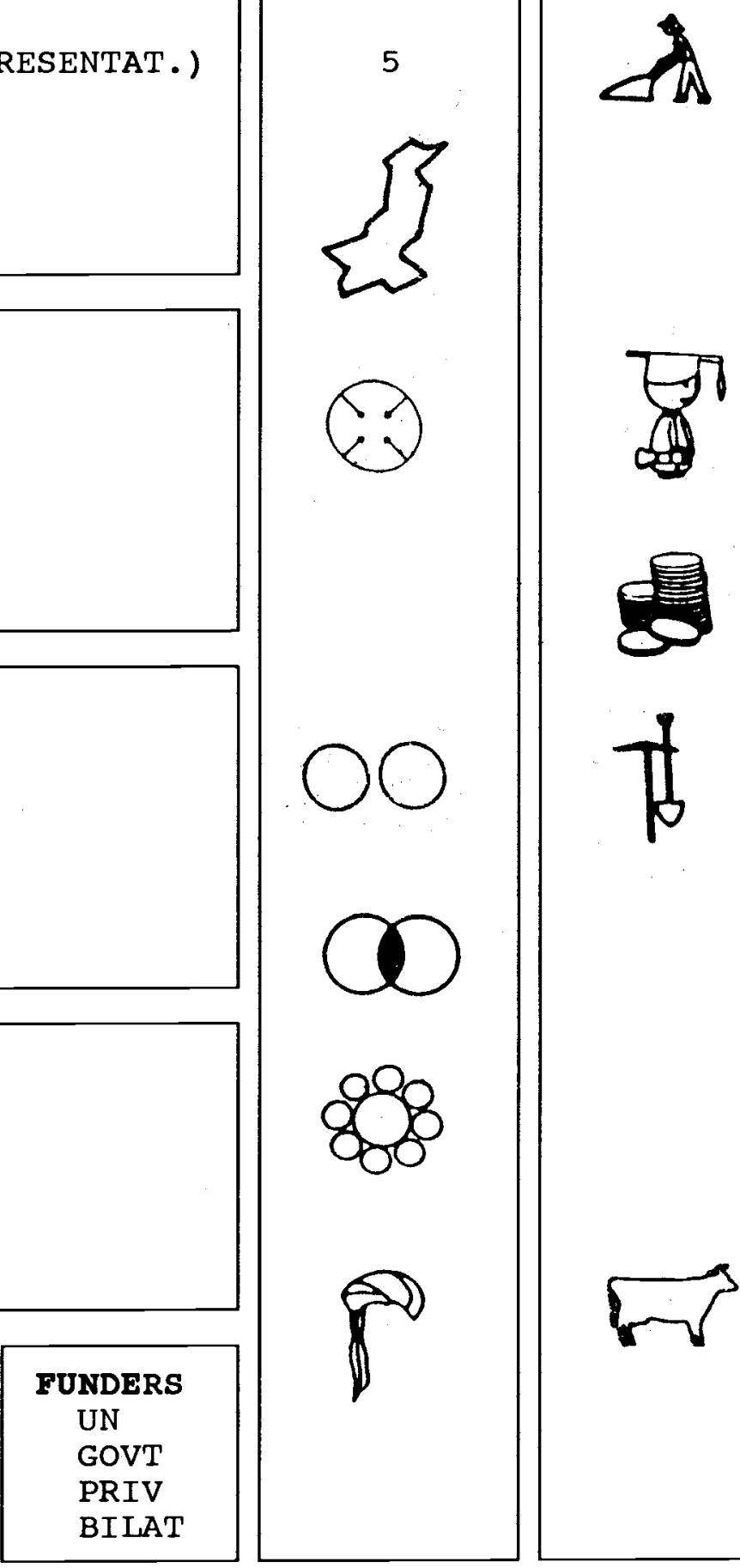

SECTOR

to

a

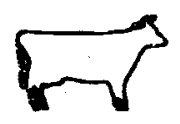

1990

\section{9}

$1,950,231$

$1,950,231$

202,546

202,546

$2,152,777$ 
AFRANE was founded in Paris in 1979, by people who were already familiar with Afghanistan and/or who had previously been there. The purpose was to establish assistance to the Afghans in this troubled period.

The first missions of humanitarian assistance started in 1980. Emergency aid was provided to the population that stayed behind in Afghanistan, under the most difficult circumstances. The assistance consisted of cash for food, blankets, clothing and the subsidizing of food stocks. Each mission inside Afghanistan was undertaken by expatriate volunteers who were authorized to decide on the use of the available funds.

After the military situation began to improve in 1986, the program orientation moved toward agricultural assistance and the rehabilitation and reconstruction of the rural environment. Priority was given to the restoration of traditional irrigation systems, such as karezes and channels. AFRANE also bought tractors.

The programs on rural development have been integrated for two years. In addition to irrigation projects, AFRANE is also involved in the distribution of seed and grain, tree plantation, livestock breed improvement, plant protection, tractor repair, support of rural schools and small projects in income generation.

These integrated programs are implemented in five provinces: Herat, Ghazni, Kandahar, Logar and in Badakhshan. AFRANE operates with the consent and cooperation of local authorities, such as shuras and commanders. Some projects operate in cooperation with other NGOs.

In 1990, AFRANE will start a special program focusing on the mechanization of agriculture.

Funding: US Government, UNDP, UNHCR and IRC. 
LOCAL ADDRESS

G P O BOX 326

PESHAWAR, PAK

10 PARK ROAD

UNIV TOWN PESHAWAR, PAK

TEL: 42419

TXL: 52369 PCOPE PK C/O MSF

FAX: 0521-42519 C/O MSF

DR. ELISABETH KIND (DIRECTOR)

DR. PHILIPPE SARROV

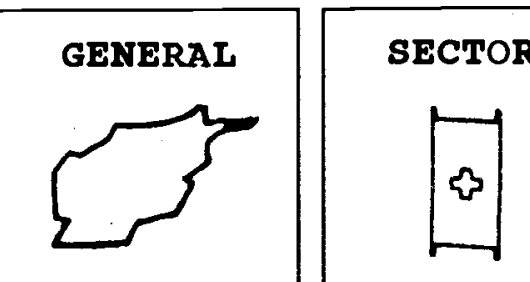

14
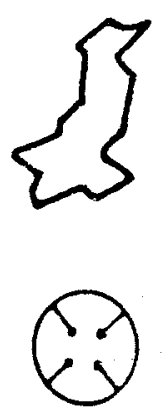

3

$\bigcirc \bigcirc$

9

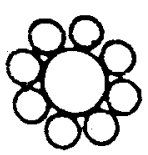

75020 PARIS FRANCE

TEL: (1) 46365151

TXL: $211772 \mathrm{~F}$ AIDMEDI

FAX:

\section{HEADQUARTERS}

DR. AGNES MALLET

AMI 119 RUE DES AMANDIERS

\section{(}

\begin{tabular}{|lrr|}
\hline \multicolumn{3}{|c|}{ PERSONNEI } \\
EXPATS & 30 & $83 \%$ \\
AFGHANS & 6 & $17 \%$ \\
PAKISTANIS & 0 & $0 \%$ \\
TOTAL & 36 & \\
\hline
\end{tabular}

\section{FUNDERS}

GOVT

PRIV

BIIAT

\section{BUDGET (US \$)}

AFGHANISTAN

PAKISTAN

TOTAL

\section{7}

20,833

76,967

97,800

\section{8}

33,296

73,806

107,102

\section{9}

90,646

203,770

294,416
1990

520,804

185,600

706,404 
A I D E D E M E D I C A L E INTERNATIONALE is a French, humanitarian association of volunteers, founded in 1979 to respond to medical emergencies affecting third-world populations which are inaccessible to international organizations like the World Health Organization and the Red Cross.

AMI sends missions of two or three doctors and nurses into Afghanistan during a three- to four-month period to help wherever their assistance is needed. Most of the volunteers sent to Afghanistan and other countries take a few months leave from their jobs (medical) in France, the United Kingdon, Belgium or Holland. Since May 1990, AMI has operated in 14 provinces of Afghanistan.

In September 1985, AMI and Solidarite Afghanistan Belgium consolidated efforts to form an autonomous joint project Medical Training for Afghans (MTA). This project operates a twenty-bed hospital with a training component, in Peshawar. The twenty Afghan nurses trained each year return to rural Afghanistan to take care of the health structures within their own regions. (For more information see Solidarite Afghanistan Belgium.).

In 1990, AMI plans to continue missions inside Afghanistan to evaluate the projects run by former trainees, as well as a study on the possibility of starting a health training project in Hazarajat. In Pakistan, AMI will begin its sixth session of medical training and organize refresher courses for former trainees.
Funding: Solidarite Afghanistan Belgium, AREFE (Belgium). Terre des Hommes, Amis Suisse de l'Afghanistan, Swedish Committee for Afghanistan, International Rescue Committee, Governments of France and Belgium and the European Community. 
LOCAL ADDRESS

$22 \mathrm{~S} J$ AFGHANI ROAD

UNIV TOWN PESHAWAR, PAK

$22 \mathrm{~S} J$ AFGHANI ROAD

UNIV TOWN PESHAWAR, PAK

TEL: 44999/(051) 820507-8

TXL: 54143 ASIAF PK (I'BAD)

FAX:

MS . ELIZABETH WHITE

MS. CARLA GRISSMANN

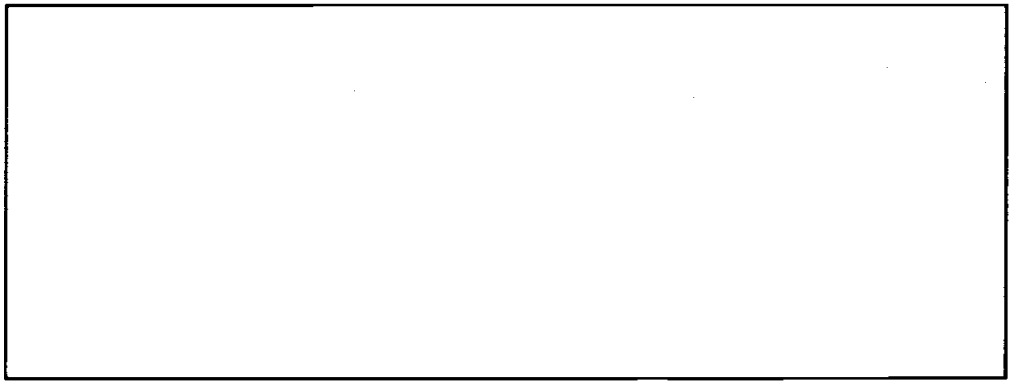

HEADQUARTERS

MR. WILLIAM MCDOUGAL

465 CALIFORNIA STREET

SAN FRANCISCO, CA 49104 USA

TEL :

TXL: 278726 ASIA UR

FAX:

\begin{tabular}{|lrl|}
\hline \multicolumn{3}{|c|}{ PERSONNEL } \\
EXPATS & 2 & $25 \%$ \\
AFGHANS & 5 & $62 \%$ \\
PAKISTANIS & 1 & $13 \%$ \\
TOTAL & 8 & \\
\hline
\end{tabular}
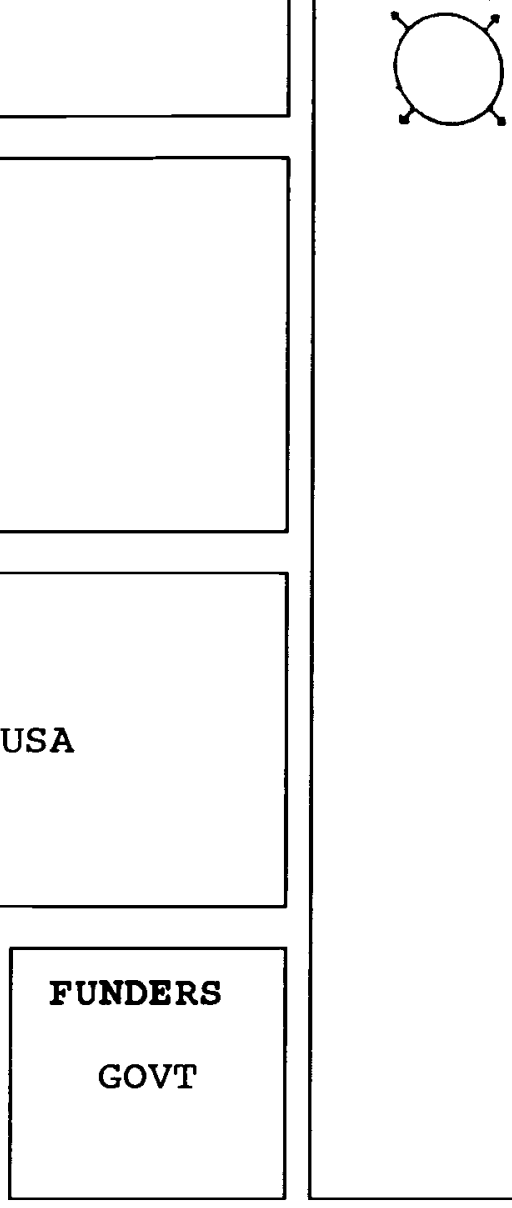

$\begin{array}{lccc}\text { BUDGET (US \$) } & 1987 & 1988 & 1989 \\ \text { AFGHANISTAN } & & 272,280 & 1990 \\ \text { PAKISTAN } & & 272,280 & 261,098 \\ \text { TOTAL } & & 261,098\end{array}$


THE ASIA FOUNDATION is a private, publicly funded grant-making organization founded in 1951 and based in San Francisco, California. It has 10 resident offices and 26 country programs in Asia. According to individual country needs, the Foundation offers support in vital areas of development, complementing larger and more impersonal bilateral or multilateral official assistance programs.

Its grant activities are largely concentrated in the areas of human resource development, public administration, education, foreign trade and investment, free enterprise and business management, economic development, international relations and diplomacy, and library development. The Foundation's Books for Asia program distributes more than one million books and journals a year to thousands of schools, universities and libraries throughout Asia.

From 1954 until 1979 the Foundation was active in Afghanistan, providing consultants, equipment/materials for institutionalizing, sponsoring exchange programs and training and modernizing public service in such institutions as: the Rural Development Department, the Higher Teachers Training College, the National Archives and Kabul Museum, Nangarhar and Kabul Universities, the Raisin and Karakul Institutes, the Women's Institute, the HelmandArgandab Valley Authority, the Academy of Science, the Ministries of Education, Agriculture, Planning, Finance, Public Health, Foreign Affairs, and others.

Future Foundation programming is under discussion, and will probably include support of AIG institutional development; ACBAR and its resource and information center (ARIC); development of professional associations; and technical/professional library development.
Funding: from a number of corporations, foundations and trusts, and major financial support from the US Department of State, smaller grants from USAID, USIA. 


\section{LOCAL ADDRESS}

G P O BOX 489

POST CODE 25000 PESHAWAR, PAK

80-D PARK ROAD

UNIV TOWN PESHAWAR, PAK

TEL: $42592 / 42584$

TXL: C/O 52365 SCA PK

FAX: C/O 42519

MR. NASSIM JAWAD (DIRECTOR)

MR. MARK ARNOLD

MR. DUR MOHAMMED FAZIL

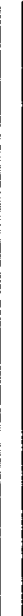

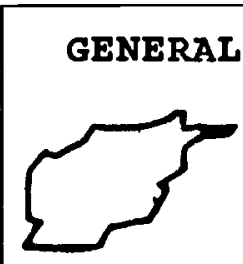

3
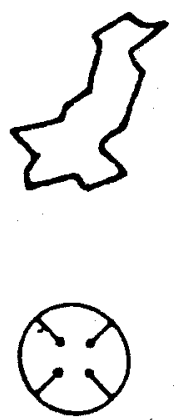

00
SECTOR

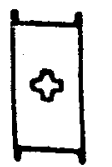

v
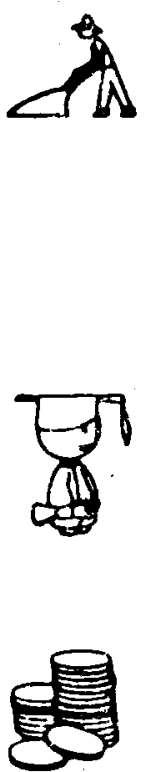

क

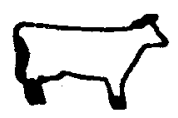

HEADQUARTERS

DR. ALFRED JANATA

SALZTORGASSE 7/6

A-1010 VIENNA, AUSTRIA

TEL: (0222) 934541

TXL:

FAX:

\begin{tabular}{|lrr|}
\hline \multicolumn{3}{|c|}{ PERSONNEL } \\
EXPATS & 6 & $3 \%$ \\
AFGHANS & 250 & $90 \%$ \\
PAKISTANIS & 20 & $7 \%$ \\
TOTAL & 276 & \\
\hline
\end{tabular}

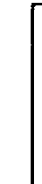

$$
\text { PA }
$$

PAit

FUNDERS

UN

GOVT

PRIV

BILAT

8




\begin{abstract}
AUSTRIAN RELIEF COMMITTEE FOR AFGHAN REFUGEES (ARC) was founded in 1980 in Vienna. It was established as a relief organization to help Afghan refugees in Pakistan and Afghans in Afghanistan.

Initially $\mathrm{ARC}$ concentrated its activities in the medical field, but since $1982 / 83$ has expanded to run projects in other fields such as sanitation, basic health education, income generation, technical training and assistance to skilled Afghans. The latter project is known as ASAR (Assistance to Skilled Afghan Refugees).
\end{abstract}

ARC runs three Primary Health Care Programmes, consisting of immunization, daily curative medicine, personal and environmental hygiene, and staff training. The latter includes training of Primary Health Workers and Traditional Birth Attendants.

Since 1982, ARC has been running sanitation and basic health education programmes in all refugee camps in NWFP and Punjab. The aims of these projects are to reduce the incidence of sanitation-related diseases by the construction and maintenance of latrines, education about sanitation and basic health.

The three Technical Training Centers are vocational training workshops, each training 100 students for one year. Practical subjects, such as carpentry, tinworking, electronics and building are taught in conjunction with theoretical basics. A literacy course has been designed for illiterate students.

ASAR carries out socio-economic surveys of camps to identify and test skilled refugees. Tools and equipment are then distributed and the beneficiaries subsequently monitored. Newly established programmes (1988) include, poultry farming, tree nurseries and sewing projects for women. Disabled people are now being incorporated into the programme. ASAR is also extending its' work into Afghanistan.

ARC has recently expanded its crossborder activities to include agricultural, irrigation and veterinary projects in Logar, Ghazni and Khandahar. These projects are specifically aimed at rural development, and though concentrating on limited areas, ARC is increasing its activities and staff numbers on this programme.

Since February 1989, the Technical Training Center in Peshawar (TTCP) has trained two groups of ten disabled students. These students were in some cases severely disabled and wheelchair bound. However TTCP successfully trained these students in typewriting skills, providing the materials and tutoring. They have since obtained employment with NGO's in Peshawar.

Funding: The Institute for International Co-operation (IIZ-Austria); Norwegian Refugee Council/Norwegian Church Aid (Norway); Bread for the World (FRD); NOVIB and Inter Church Aid (Netherlands); Oxfam (U.K.); HEKS (Switzerland) and UNHCR. 


\section{LOCAL ADDRESS}

C/O ACBAR

UNIV P O BOX 926 PESHAWAR, PAK HOUSE 1237, ACADEMY TOWN

ALI ROAD, UNIV TOWN, PESHAWAR

TEL： 43875

TXL:

FAX:

MR. JOSEPH STEELE

MR. WILLIAM HUTH

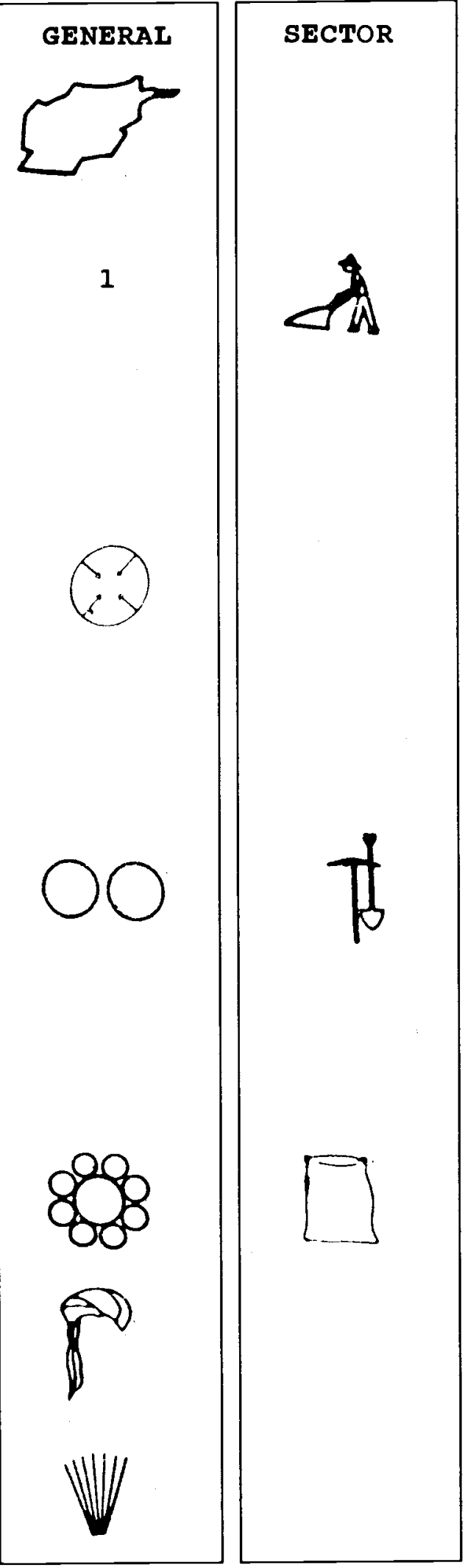

BILAT

\section{HEADQUARTERS}

MR. PETER REITZ

8 AVENUE BUGEAUD

75116, PARIS FRANCE

TEL: $331 \quad 4 \quad 7550008$

TXL: $842648806 \mathrm{~F}$

FAX: 011 331-47-04-73-89

\begin{tabular}{|lrr|}
\hline \multicolumn{3}{|c|}{ PERSONNEL } \\
EXPATS & 3 & $11 \%$ \\
AFGHANS & 22 & $81 \%$ \\
PAKISTANIS & 2 & $8 \%$ \\
TOTAL & 27 & \\
\hline
\end{tabular}

\section{FUNDERS}

PRIV
BUDGET (US \$) 1987

AFGHANISTAN

PAKISTAN

TOTAL
1988

1989 
The presence of CARE INTERNATIONAL in Pakistan is for the sole purpose of providing a base of operations for support of Afghan refugees who have returned to Afghanistan and displaced persons within Afghanistan. The major purpose of support is to provide food security for a limited period of time to those Afghan families engaged in rehabilitating their homes, land and general environment.

The means of providing food is initially through Food-for-Work projects organized and managed by local shuras and those entities cooperating with and supporting them. As needs change, Food-for-Work may develop into a combination of cashand food-for-work.

Funding: donations of individuals, private companies, foundations and IRC. 
LOCAL ADDRESS

P O BOX 1657

ISLAMABAD, PAK

HOUSE 31-B STREET 34

$F-7 / 1$ ISLAMABAD, PAK

TEL: (051) 824342

TXL: 5668 AMXCO PK

FAX:

MR. JOHN G. CONNOLLY

\section{SUBOFFICE 1}

CRS, A K KHAN'S HOUSE MOHALLAH HUSSAIN ABAD

NARI INDUS, MIANWALI, PAK

TEL：(051) 824342

MS. A. SCARFE

\section{SUBOFFICE2}

P O BOX 452

QUETTA

PAK

TEL：(081) 44853

MS. E . NEUENSCHWANDER

MS . L. DUBOIS

MR. P. HEINZEN

\section{HEADQUARTERS}

MR. JOSEPH S. CURTIN

209 WEST FAYETTE STREET

BALTIMORE, MD 21201 USA

TEL: (301) 625 2220

TXL: 9100000951 CRS

FAX: $212-838-4624$

\begin{tabular}{|lrr|}
\hline \multicolumn{3}{|c|}{ PERSONNEL } \\
EXPATS & 5 & $5 \%$ \\
AFGHANS & 62 & $60 \%$ \\
PAKISTANIS & 36 & $35 \%$ \\
TOTAL & 103 & \\
\hline
\end{tabular}

\begin{tabular}{|lcccc|}
\hline BUDGET (US \$) & 1987 & 1988 & 1989 & 1990 \\
AFGHANISTAN & & & & 119,775 \\
PAKISTAN & 496,912 & 516,327 & 727,228 & 699,595 \\
TOTAL & 496,912 & 516,327 & 727,228 & 819,370 \\
\hline
\end{tabular}

\section{GENERAL}
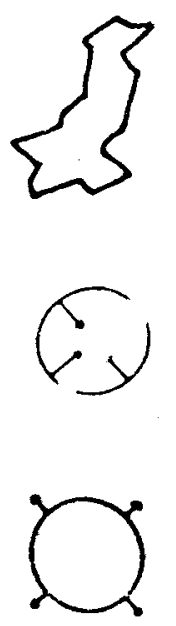

$\bigcirc$
SECTOR

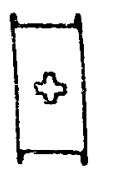

c

-

n

FUNDERS

UN

GOVT

PRIV.

BILAT 
CATHOLIC RELIEF SERVICES (CRS) is an international relief and development NGO with headquarters in the United States and projects in over fifty countries worldwide. CRS has been active in Pakistan since 1956. Initial involvement with Afghan refugee relief in Pakistan began in 1983, with CRS as a funding agency. However, since 1986, CRS has implemented Pakistan-based refugee projects.

CRS has three projects for Afghan refugees in Pakistan. Two projects are in the health and sanitation sector, one based in Baluchistan and the other in Mianwali. These two projects concentrate on providing sanitation facilities to the Afghan refugees, in health education and the training of community health workers, sanitation outreach workers and traditional birth attendants.

The combined achievements of these two projects are 10,000 latrines constructed, 188 male community health workers trained, 288 female community health workers trained, 350 traditional birth attendants trained, and 20 outreach workers trained.

The third relief project, based in Baluchistan supports Afghan refugee training and income generation. This project provides training in the production of clothing and related items to needy Afghan women and disabled men, and also offers them a marketing outlet for their production. Since the inception of the project in 1986, approximately 2000 Afghan refugee women and 50 disabled men have participated in the project.

An agricultural project is in the planning stage for inside Afghanistan. As foreseen, the project will provide seeds, fertilizer, and rehabilitation of irrigation systems.

Funding: US Government and UNHCR. 


\section{LOCAL ADDRESS}

KHATTAK HOUSE, OLD BARA RD

AFZAL ABAD PESHAWAR, PAK

KHATTAK HOUSE, OLD BARA RD

AFZAL ABAD PESHAWAR, PAK

TEL: 42405

FAX:

MR. STEVE MASTY

MS. ANNE E. HURD
TXL: 52484 HNS PK

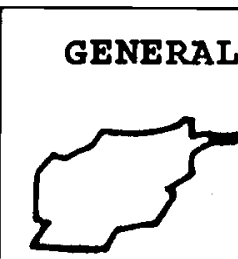

3
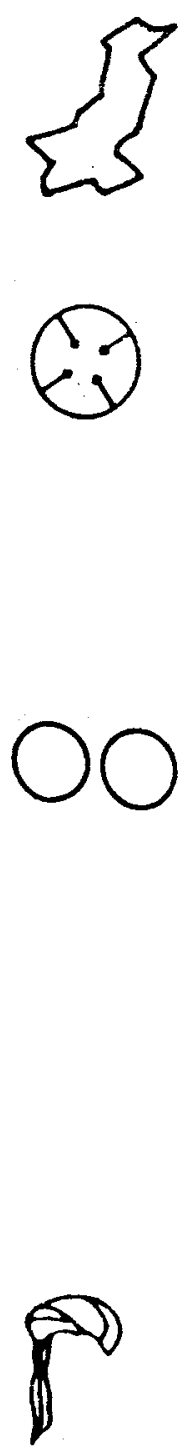

FUNDERS

MR. ANDREW J . KOVAL

1000 POTOMAC ST

WASHINGTON, DC 20007 USA

TEL:

TXL: 279675 WASH UR

FAX: $202-342-6576$

\begin{tabular}{|lrr|}
\hline \multicolumn{3}{|c|}{ PERSONNEL } \\
EXPATS & 4 & $1 \%$ \\
AFGHANS & 1200 & $96 \%$ \\
PAKISTANIS & 40 & $3 \%$ \\
TOTAL & 1244 & \\
\hline
\end{tabular}

1987

AFGHANISTAN

110,907

TOTAL

138,733
GOVT

PRIV

BILAT
SECTOR
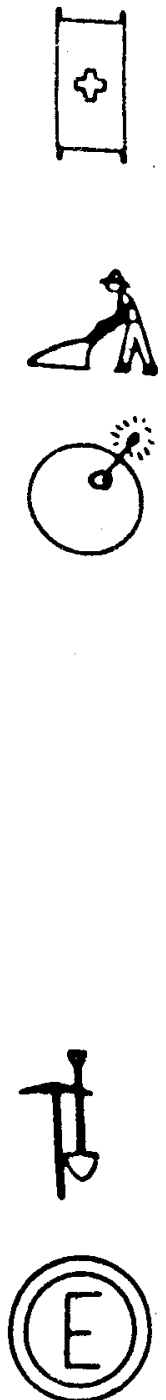

$$
4
$$$$
+
$$ 
The COUNCIL FOR INTERNATIONAL DEVELOPMENT (CFID) is based in Washington, D.C. and oversees development and relief programs on three continents. Its programs in Pakistan and Afghanistan are commonly known by its earlier name, MERCY FUND.

Employing more than one thousand people in Pakistan and Afghanistan, CFID currently receives funding from the U.S. Department of State's Bureau of Refugees and USAID; however, in Fiscal Year 1988 about 80 percent of its programs in this region were financed by private donations.

CFID first began refugee relief work in Peshawar in 1986, and now runs mobile ob-gyn clinics treating nearly 50,000 refugee women each year. Three mobile units, with Afghan women doctors and female support staff, each week visit eighteen camps in the Kohat, Peshawar, and Mardan Districts and work out of semi-permanent clinic sites.

CFID is also a pioneer in mine-awareness education, having produced innovative and self-explanatory educational tools designed for illiterates without access to teachers. They ran the first-ever mine-awareness training program for men and women in Shamshattu refugee camp, teaching hundreds of families safe ways of escaping the hazards of mines on their eventual return to Afghanistan.

Across the Durand Line, CFID delivers tons of food and clothing to the displaced around Jalalabad, allowing them to survive near their homes and not add to the burden borne by Pakistan's refugee camps. CFID also runs first-aid clinics in several sites in Nangahar and Kabul Provinces.

In May 1989, resistance forces asked CFID to manage enormous state farm complexes outside Jalalabad. Originally built by the Soviets in the 1960 s, these farms contain nearly a million olive trees and extensive citrus orchards. The potential cash value of the crop comes close to $\$ 50$ million per year and represents pre-war Afghanistan's fourth largest export commodity.

Today the CFID staff is clearing irrigation canals, rebuilding locks, weeding and otherwise ensuring that the endangered trees survive. CFID agriculturists are also devising ways of processing and marketing the crop.

Funding: US Government, USAID and private donations. 
LOCAL ADDRESS

$P$ O BOX 855

UNIV TOWN PESHAWAR, PAK

10 GULMOHAR LANE

UNIV TOWN PESHAWAR, PAK

TEL: $42516 / 43084$

TXL: 52307 DACAR PK

FAX:

MR. LEIF FRIDORF (REPRESENTATIVE) FROM APRIL 1990:

MR. ERIK CHRISTENSEN (REPRESENT.)

MR. AGGER CHRISTENSEN

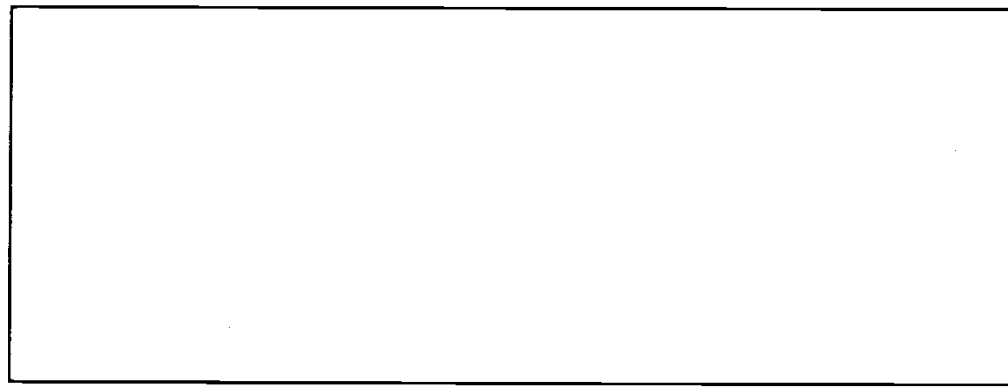

HEADQUARTERS

MR. NIELS BENTZEN

DANISH REFUGEE COUNCIL

$P$ O BOX 53 COPENHAGEN K, DENMARK

TEL: 1912700

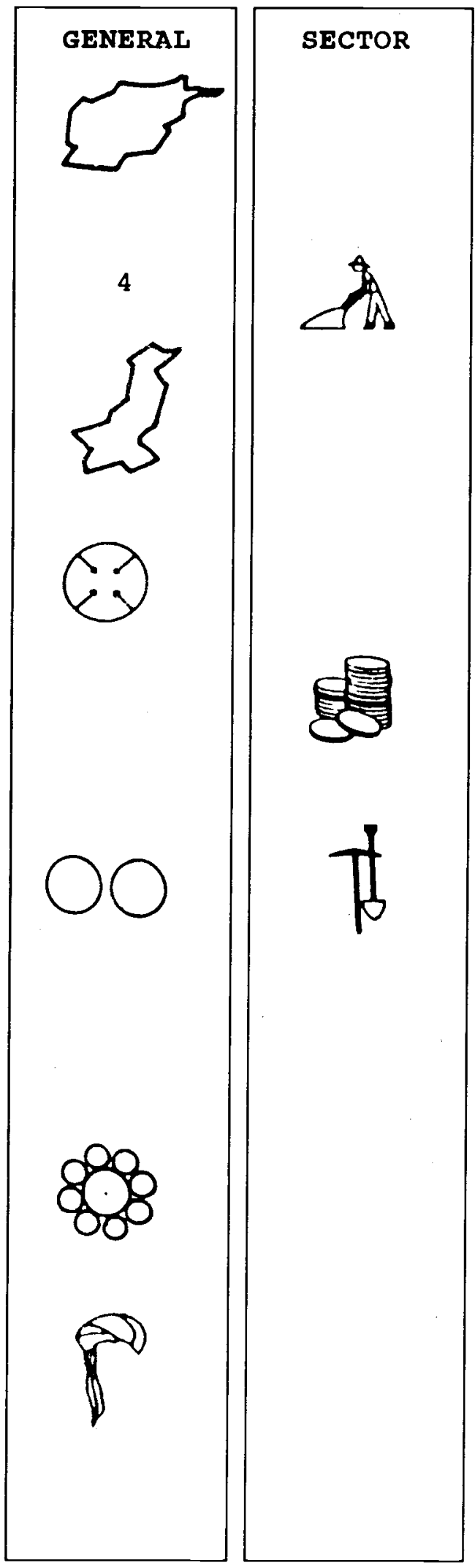

TXL: 19581 REFUCO DK

FAX: 1328448

\begin{tabular}{|lrr|}
\hline \multicolumn{3}{|c|}{ PERSONNEL } \\
EXPATS & 10 & $2 \%$ \\
AFGHANS & 353 & $82 \%$ \\
PAKISTANIS & 70 & $16 \%$ \\
TOTAL & 433 & \\
\hline
\end{tabular}

\begin{tabular}{|l|}
\hline FUNDERS \\
UN \\
GOVT \\
PRIV \\
\hline
\end{tabular}

$$
36
$$

BUDGET (US \$) 1987 AFGHANISTAN

PAKISTAN

TOTAL
$2,612,355$

$2,612,355$
1988

$$
2,532,802
$$$$
2,532,802
$$

1989

979,431

$3,292,476$

$4,271,907$

\section{0}

$2,103,786$

$1,945,254$

$4,099,040$ 
DANISH COMMITTEE FOR AID TO AFGHAN REFUGEES (DACAAR) is a consortium set up to aid Afghan refugees, composed of four Danish NGOs: Danish People's Relief Organization, Danish Association for International Cooperation, Caritas Denmark and Danish Refugee Council.

It has run its own projects in Pakistan since 1984 and during 1988 began to plan a rehabilitation programme for Afghanistan.

The DACAAR sewing project in the refugee camps gives an income to $7 \dot{4} 7$ Afghan women, from embroidery and tailoring, by producing items for export, local sales, and UNHCR contracts. Mobile teams teach embroidery and new designs as well as looking after quality control of the work done by women in the camps, and a six month course trains women to work in the finishing workshop in Peshawar.

DACAAR employs refugees in construction teams for site planning and the provision of improved access roads in the camps. They took over the UNICEF water supply project in 1986 to improve and maintain shallow wells and handpump installations, and they also build bathrooms and produce health education materials relating to water and hygiene.

DACAAR is also responsible for the maintenance of all piped water systems to refugee camps which have been installed by the NWFP Public Health Engineering Department. In 1988 their factory in Swabi began production of Indus handpumps, including a large number for UNHCR.

Plans are now being developed for DACAAR's work in Afghanistan in irrigation, drinking water supply, roads and construction, in the provinces of
Kunar, Logar, Ghazni and Paktika. A graduate training scheme for engineers and foremen is being developed in Pakistan.

An example of DACAAR's activities is the construction of a suspension bridge in Khazana Camp. This camp, twenty-five $\mathrm{km}$ north of Peshawar is divided in two by the Kabul river. Refugees could not reach the island part of the camp by foot and the water supply pipeline was constantly being damaged by flood waters. DACAAR decided to build a suspension bridge funded by a Swedish group, Diakonia. This was very much a pilot project, and was a new area of work for the members of the shallow well construction team who worked on the bridge. The bridge spans 50 meters with a width of 1.2 meters and its reinforced concrete supporting columns carry a steel cable from which a walkway of mulberry wood is suspended. The bridge was opened in November 1988.
Funding: Danida, the Danish Refugee Council, the European Community and UNHCR. 
LOCAL ADDRES8

G P O BOX 356

POST CODE 25000 PESHAWAR, PAK

JAMAL STREET SHAHEEN TOWN

JAMRUD ROAD PESHAWAR, PAK

TEL: 43358

TXL:

FAX:

DR. SHER AQA BALUCH (DIRECTOR)
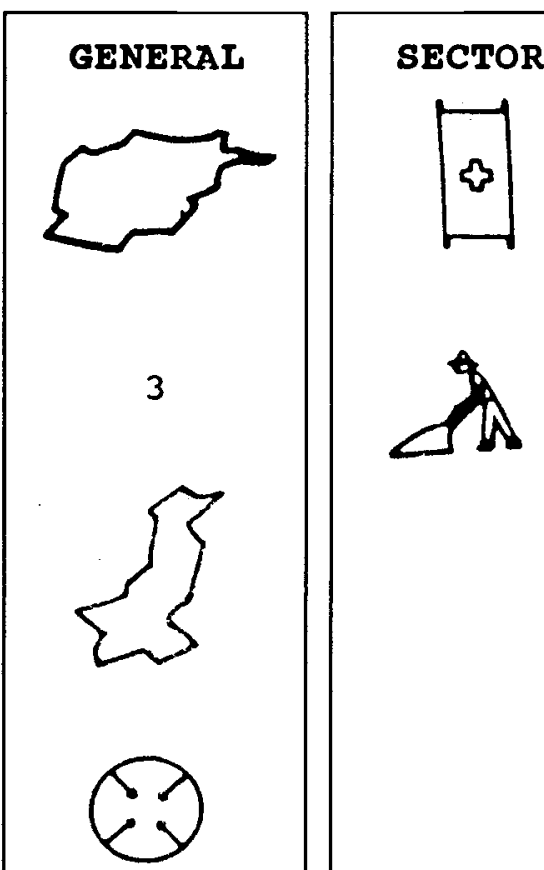

$\bigcirc \bigcirc$

\section{HEADQUARTERS}

DR. SHER AQA BALUCH

G P O BOX 356

POST CODE 25000 PESHAWAR, PAK

TEL : 43358

TXL:

FAX:

\begin{tabular}{|lrr|}
\hline \multicolumn{3}{|c|}{ PERSONNEL } \\
EXPATS & 1 & $2 \%$ \\
AFGHANS & 62 & $95 \%$ \\
PAKISTANIS & 2 & $3 \%$ \\
TOTAL & 65 & \\
\hline
\end{tabular}

\begin{tabular}{|l} 
FUNDERS \\
UN \\
PRIV
\end{tabular}

\section{BUDGET (US \$) 1987}

AFGHANISTAN

PAKISTAN

TOTAL

\section{8,611 \\ 48,611}

\section{8}

16,648

88,035

104,683

\section{9}

59,582

94,025

153,607

\section{0}

94,576

108,835

203,411 


\section{The DENTAL CLINIC FOR AFGHAN}

REFUGEES (DCAR) started its activities in January 1984. In November of 1986, in addition to the main clinic, dental care to the refugees was extended to the operation of three dental, mobile units which provide service to various camps.

The main clinic consists of eight Mobile Dental Units, sponsored by HELP of West Germany and an E.N.T. Department which started its activities in 1989. Since 1988, a Dental Training Course has been conducted.

In addition to the above, three dental clinics are operating in Logar, Maidan and Mazar-i-Sharif inside Afghanistan.

Under the sponsorship of UNHCR, the organization has started an agricultural assistance program in Mohammad Agha District, Logar Province, to increase the crop production of the farmers.

Funding: $\quad$ HELP(FRG), UNHCR and WHO. 
LOCAL ADDRESS

$P$ O BOX 896

UNIV TOWN PESHAWAR, PAK

F-27 K. K. KHATTAK ROAD

UNIV TOWN PESHAWAR, PAK

TEL: 45417

TXL:

FAX:

MR. CORNIE HUIZENGA (PROJ. MANAG.)
GENERAL

SECTOR
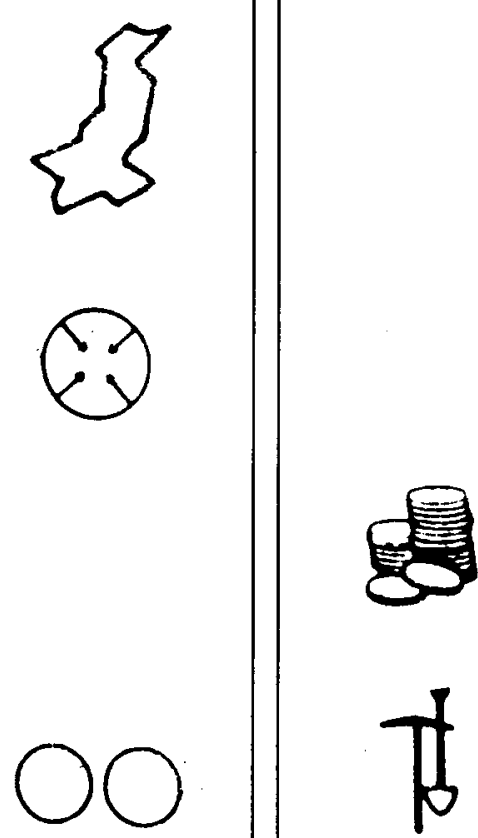

\section{HEADQUARTERS}

ULLRICH

G T Z, P O BOX 5180

D8236 ESCHBORN 1 WEST GERMANY

TEL:

TXL:

FAX: (0) 6196792269

\begin{tabular}{|lrr|}
\hline \multicolumn{3}{|c|}{ PERSONNEL } \\
EXPATS & 4 & $7 \%$ \\
AFGHANS & 50 & $88 \%$ \\
PAKISTANIS & 3 & $5 \%$ \\
TOTAL & 57 & \\
\hline
\end{tabular}

$$
40
$$

BUDGET (US \$)

AFGHANISTAN

PAKISTAN

TOTAL

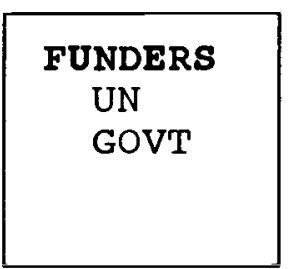

1988

554,938

554,938

\section{9}

489,715

489,715 c

c 
The DOMESTIC ENERGY SAVING PROJECT (DESP) was established in 1984. The aim of the project was to develop and disseminate energy- saving cooking and baking technologies for Afghan Refugee households in the RTV's (Refugee Tented Villages) in NWFP.

In recent years the project has also become involved in the training of masons and the construction of clay-domed houses in the camps - the rationale being that this innovation would also lead to a saving of wood. At the same time it would be a useful preparation for the repatriation of Afghan refugees. Women have always formed the most important target group of the project.

From the time the project was established, it was intended that technologies developed should be transferable to both the Afghan and Pakistani populations of NWFP. Furthermore, it was planned that repatriating refugees would take the technologies developed with them to Afghanistan.

In addition the project is also implementing a sub-project in the framework of "The Second Phase IncomeGenerating Project for Refugee Affected Areas."

At present the project is working mostly in Afghan RTVs in different parts of NWFP. Since its establishment, about 100,000 households have adopted one of the project technologies; this includes Pakistani households who live in the vicinity of RTVs. Of special importance are the approximately 750 bakeries which have been established with the support of the project. These have played an important role in feeding the refugees, saving fuel and the provision of incomegeneration opportunities.
The project is now considering how to expand its activities to Afghanistan. Apart from pilot dissemination activities the emphasis during the first months will be on the collection of information. The collection of information (as well as later dissemination activities) will be conducted in cooperation with other agencies who have more extensive experience in working in Afghanistan. This approach reflects the opinion of the project that environmental protection is an issue that cannot be handled by one agency only, but should be a shared responsibility of all groups involved in the reconstruction of Afghanistan.

In addition, in 1990, the project will initiate a training and research program in the field of low-cost housing and construction as part of the preparation program for repatriation.

Funding: German Agency for Technical Cooperation (GTZ), UNHCR, a consortium of European countries, and the World Bank. 

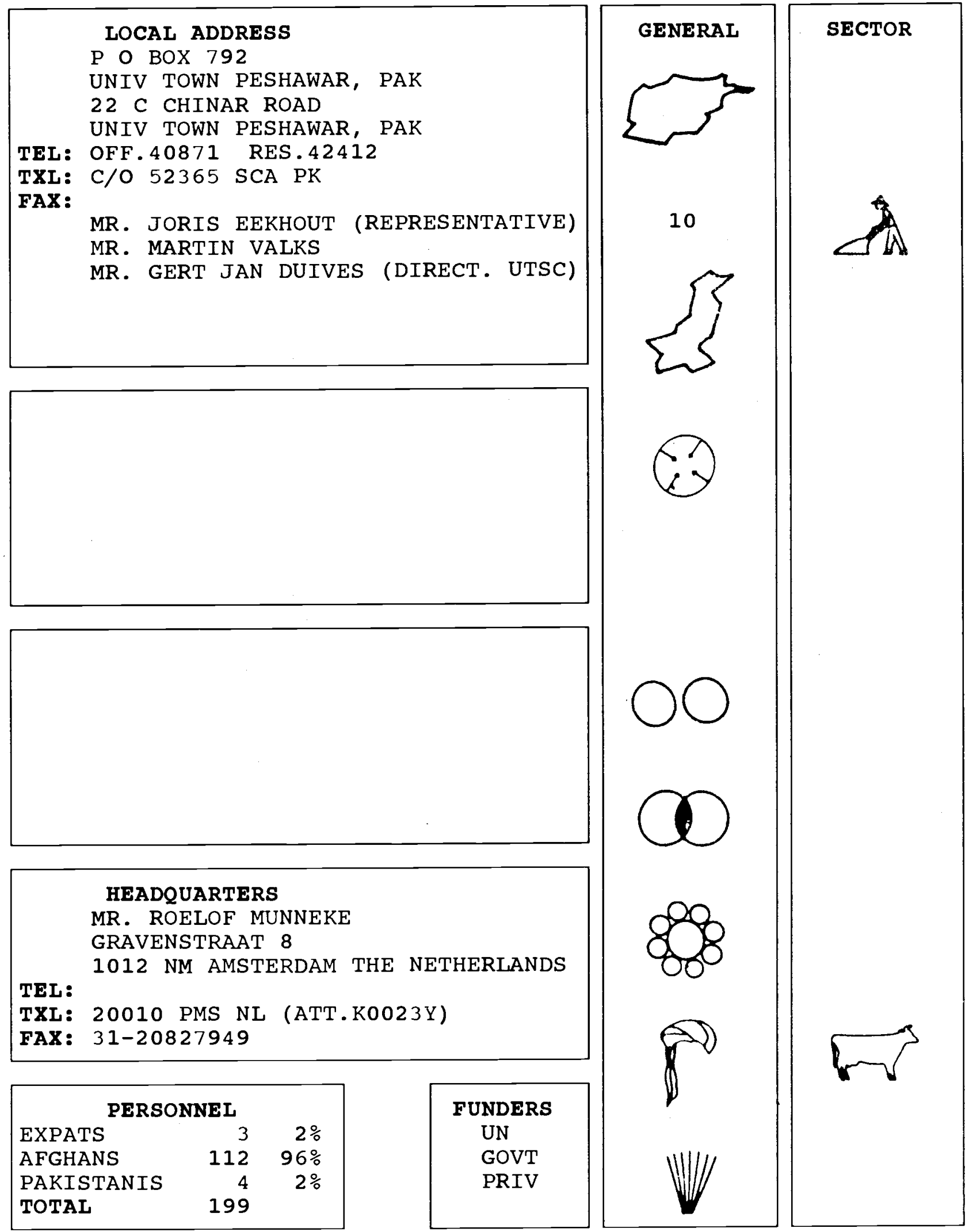

\section{HEADQUARTERS}

MR. ROELOF MUNNEKE

GRAVENSTRAAT 8

1012 NM AMSTERDAM THE NETHERLANDS

TEL:

TXL: 20010 PMS NL (ATT.K0023Y)

FAX: $31-20827949$

\begin{tabular}{|lrr|}
\hline \multicolumn{3}{|c|}{ PERSONNEL } \\
EXPATS & 3 & $2 \%$ \\
AFGHANS & 112 & $96 \%$ \\
PAKISTANIS & 4 & $2 \%$ \\
TOTAL & 199 & \\
\hline
\end{tabular}

\begin{tabular}{|l|}
\hline FUNDERS \\
UN \\
GOVT \\
PRIV \\
\hline
\end{tabular}

BUDGET (US \$) 1987

AFGHANISTAN 289,351

PAKISTAN

TOTAL
289,351

\section{8}

249,722

320,310

570,032

\section{9}

393,159

529,355

922,514

\section{0}

375,236

830,790

$1,206,026$ 
The DUTCH COMMITTEE FOR AFGHANISTAN (DCA) is based in Peshawar, with its head office in Amsterdam, The Netherlands, under the name "Stichting Afghanistan Comite Nederland."

Since 1985, DCA has largely concentrated its assistance inside Afghanistan through cross-border assistance projects. Operations started with cash-for-food assistance mainly in northeast Afghanistan (Panjshir). This type of assistance was, over the following years extended to 15 areas in north, east, and northeast Afghanistan.

Beginning in 1988, other types of assistance were planned in order to meet new requirements caused by the changing political-military situation. An increasing demand for more structural types of assistance in the veterinary and agricultural sector was emerging, and there was need for programs to be designed to begin rehabilitation of the agricultural economy.

A major constraint perceived by farmers was their loss of livestock, including draught animals, caused by the war, epidemic diseases and slaughtering. Rehabilitation began in the veterinary sector by developing a system of preventive animal health care in the rural areas.

DCA entered the first phase of the project in September 1988, with the establishment of the Veterinary Training and Support Center (VTSC), an institute training approximately 90 vaccinators and 40 paravets a year for various NGO's interested in integrating animal care into their agricultural programs. The training component of the VTSC provides refresher courses for Afghan veterinarians who want to work inside Afghanistan. The support component provides standardized field kits for each level of veterinary assistance, ranging from vaccinators and paravets to complete field units (consisting of an Afghan veterinarian assisted by paravets). DCA has established four field units that integrate the different levels into one coordinated structure, making it possible to cover large areas and to react quickly to major out-breaks of animal diseases. By the end of 1990, DCA is planning to have established 10 additional field units.

The second phase of DCA assistance started in the early part of 1989 and involves both veterinary-related projects distribution of draught animals and milk cows, and breeding programs for livestock - and those related to other sectors of agriculture, such as irrigation, seed and fertilizer, and tractor power. Ideally, these different sectors of assistance will be integrated where DCA has established a veterinary health structure. These rural reconstruction schemes will be supervised in the field by the veterinary staff of the field unit and additional specialists in agriculture, irrigation and animal husbandry.

Funding: Dutch Government, UNDP, FAO, and private donors in The Netherlands. 


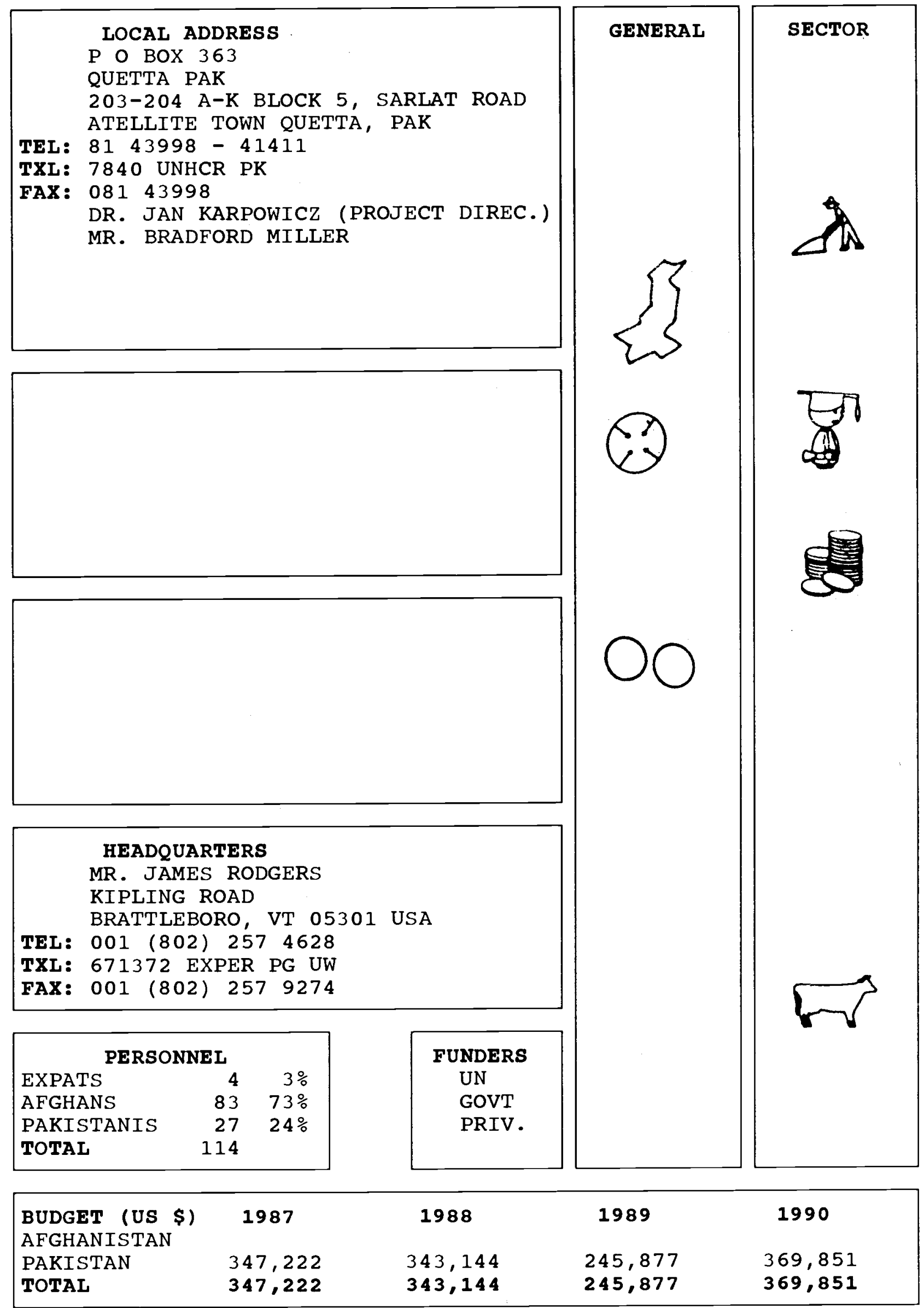


T h e E X P E R I M E N T I N INTERNATIONAL LIVING (EIL) is a non-profit NGO headquartered in Brattleboro, Vermont, USA. Its operations in Balochistan are one facet of world-wide activities involving refugee resettlement in third world countries, language training, teacher and teacher-trainer education, assisting indigenous non-governmental agencies to strengthen management, cooperative and implementing capabilities and human resource development.

In Balochistan, EIL implements and manages projects that focus on: Afghan refugee assistance through primary and middle school teacher training and materials/curriculum development; agricultural assistance/income generation; and a women's integrated income generation program.

The Education and Materials/Curriculum Development Program, started in 1987, employs men and women trainers who provide pedagogical and content training for some 180 Afghan village teachers. Six Education Resource Centers, permanently staffed, provide back-up, field monitoring and material support to teachers. The Quetta staff provides in-service training of trainers monthly. A locally appropriate training manual has been created for both male and female teachers. In addition, Pashtu and Dari textbooks are translated and produced; approximately 6,000 of these tests have been printed and distributed this year. At least 6,000 students in grades 1 - 3 have been reached.

The Agricultural Assistance/Income Generation Project covers most activities likely to be engaged in by agriculturalists and livestock owners. Through August 1989, material and technical support was provided to 5,800 families in kitchen gardening and livestock. Ten Agricultural Support Centers provide supplies, at cost or marginally subsidized rates; veterinary services are provided, utilizing a pool of skilled stock assistants. About 10,000 animals (plus poultry) are treated gratis per month.

Other areas of assistance involve poultry distribution and subsidized poultry feed to refugee families, the development of water sources for irrigation and livestock use, support to especially needy families in the form of inputs and advice. Also, tree seedlings are raised in small nurseries by families who are paid for their work, thus creating income.

In spring 1989, an Integrated Womens' Income Generation project was implemented. Starting with traditional female activity of handicrafts/embroidery production, EIL successfully demonstrated that women can become income generaters without detracting funds from more standard male programs. Currently, 150 women are engaged in this activity which aims at self-financing, sustainability and replicability inside Afghanistan.

Funding: UNHCR and the US Bureau of Refugee Programs. 


\section{LOCAL ADDRESS}

4-A RAILWAY ROAD

UNIV TOWN PESHAWAR, PAK

4-A RAILWAY ROAD

UNIV TOWN PESHAWAR, PAK

TEL: $42505 / 42300$

TXL: 52458 FRMED PK

FAX: 42512

MR. ROBERT H. BRENNER (REPRESENT.)

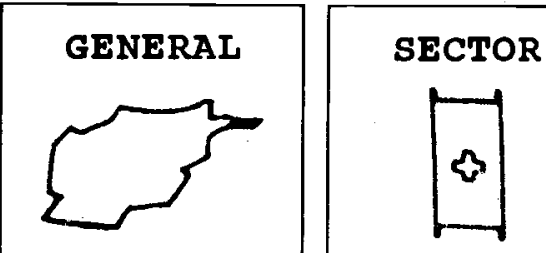

27
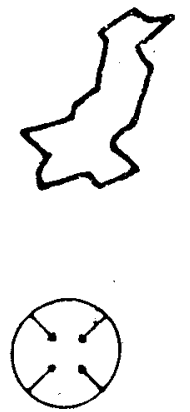

$\bigcirc$

\section{HEADQUARTERS}

MR . SCOM BRENHER

$3299 \mathrm{~K}$ ST NW, SUITE 700

WASHINGTON, DC 20007 USA

TEL: (202) 342-9338

TXL: 6503720282 MCI UW

FAX:

\begin{tabular}{|lrr|}
\hline \multicolumn{3}{|c|}{ PERSONNEL } \\
EXPATS & 16 & $11 \%$ \\
AFGHANS & 134 & $88 \%$ \\
PAKISTANIS & 2 & $1 \%$ \\
TOTAL & 152 & \\
\hline
\end{tabular}

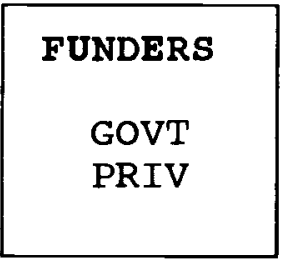

$$
46
$$

(US \$) 1987

FGHANISTAN

628,179

$1,068,102$

1988

1989

1990

862,395

$1,978,998$

$1,360,998$

465,946

1,042024

$1,801,059$

$1,696,281$

$3,021,022$

$3,162,057$ 
FREEDOM MEDICINE (FM) is a health-care training organization established in 1985. The agency originally focused solely on the Afghan situation; in subsequent years it has expanded and has conducted similar training projects in several other parts of the world.

The paramedic training program operated by Freedom Medicine, is currently under revision. In August 1989, the tenth and final paramedic class graduated, bringing the total number of FM graduates to 181 .

In January 1990, Freedom Medicine will begin a three-month, advanced training program for paramedics who seek to upgrade their skills. In addition, a new Maternal and Child Health Education initiative targeted at refugee women is underway at the Chitral clinic.

Finally, Freedom Medicine has been working with the Ministry of Health for the Afghan Interim Government to develop a mechanism by which the Ministry can assume control of Freedom Medicine facilities and programs in Pakistan and in Afghanistan.

Funding: USAID and private donors. 


\section{LOCAL ADDRESS}

23 C PARK AVENUE

UNIV TOWN PESHAWAR, PAK

23 C PARK AVENUE

UNIV TOWN PESHAWAR, PAK

TEL: $42446 / 42588 / 42138$

TXL: 52464 GAC PAC

FAX: 42223

DR. REINHARD EROES, M.D. (DIRECT.)

DR. PETER SCHWITTECK

DR. MICHEL MULLER, M.D.

DR. ORTWIN JOCH, M.D.

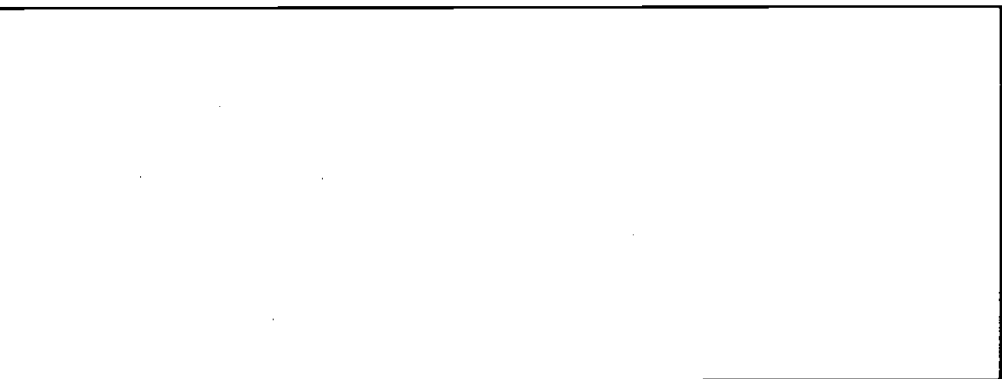

HEADQUARTERS

MR. DIETRICH KANTEL

DEUTSCHES AFGHAN KOMITEE

AM BOMMERICH 2, D-5300 BONN 2, W GERMANY

TEL: $\begin{array}{llll}228 & 38 & 34 & 32\end{array}$

TXL: 886834 FSBBO D

FAX: $228 \quad 384534$

\begin{tabular}{|lrr|}
\hline \multicolumn{3}{|c|}{ PERSONNEL } \\
EXPATS & 10 & $4 \%$ \\
AFGHANS & 250 & $95 \%$ \\
PAKISTANIS & 2 & $1 \%$ \\
TOTAL & 262 & \\
\hline
\end{tabular}

\section{BUDGET (US \$) 1987}

$\begin{array}{lr}\text { AFGHANISTAN } & 1,157,407 \\ \text { PAKISTAN } & 289,351 \\ \text { TOTAL } & \mathbf{1 , 4 4 6 , 7 5 8}\end{array}$

332,963

$1,720,310$

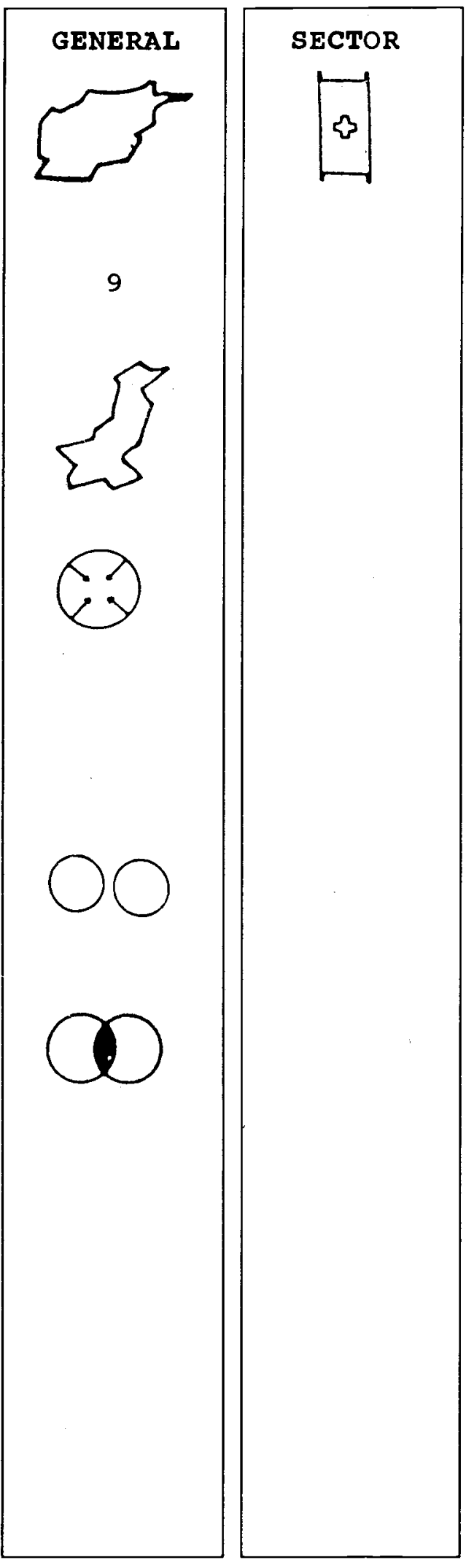

\section{9}

1990

$1,387,347$

$1,469,147$

293,829

$1,762,976$

$2,477,793$

701,262

$3,179,055$ 
Since 1984, the GERMAN AFGHANISTAN COMMITTEE (GAC), as an implementor, has provided quality medical facilities, personnel and medical training in selected areas of Afghanistan and to non-registered refugees in Pakistan.

In Pakistan the Committee operates: a hospital at Sadda (Kurram Agency) with O.T. and lab, staffed by three Afghan physicians and six Afghan nurses; a hospital at Miram Shah (N. Waziristan) O.T. only, staffed by an Afghan female gynecologist, an Afghan male specialist in internal medicine, and six Afghan nurses.

In Peshawar, GAC operates a program of plastic surgery for Afghans in which 15 German teams of plastic surgeons work in selected hospitals (a joint-venture with HELP - Germany and INTERPLASTGermany). Under its auspices the German Afghanistan Committee has supplied Afghan health-workers and medicaltraining facilities with 15,000 copies of "Medical Hand Book."

In Afghanistan the Committee operates a surgical training hospital in Wardak (constructed in 1989), with O.T. and X-ray lab. A German-Swiss team make up the staff of the 35-bed facility, which also houses a nurses' training school. Furthermore, there are twelve OPD's in nine provinces (Samangan, Bamian, Wardak, Baghlan, Paktia, Logar, Ghazni, Nangarhar, Kunar) staffed by 13 Afghan physicians, 96 Afghan nurses/health workers, and nine German/Swiss surgeons/specialists for tropical diseases.

Planned for 1990 are a surgical training hospital in Samangan and a hospital in Achin in cooperation with Afghanaid, U.K.

In 1989, using its own transport fleet, the German Afghanistan Committee transported 82 MT of medicines and medical equipment into Afghanistan.

Funding: $\quad$ some 40,000 private donors in FRG, Germa n Government, European Com m u n i y, U S Government, UNOCA and UNHCR. 


LOCAL ADDRESS
G P O BOX 1230
POST CODE 25000 PESHAWAR, PAK
10/D-1 "A"
HAYAT ABAD PESHAWAR, PAK
TEL: 48486
TXL:
FAX:
MR. A. R. GHAFOORI

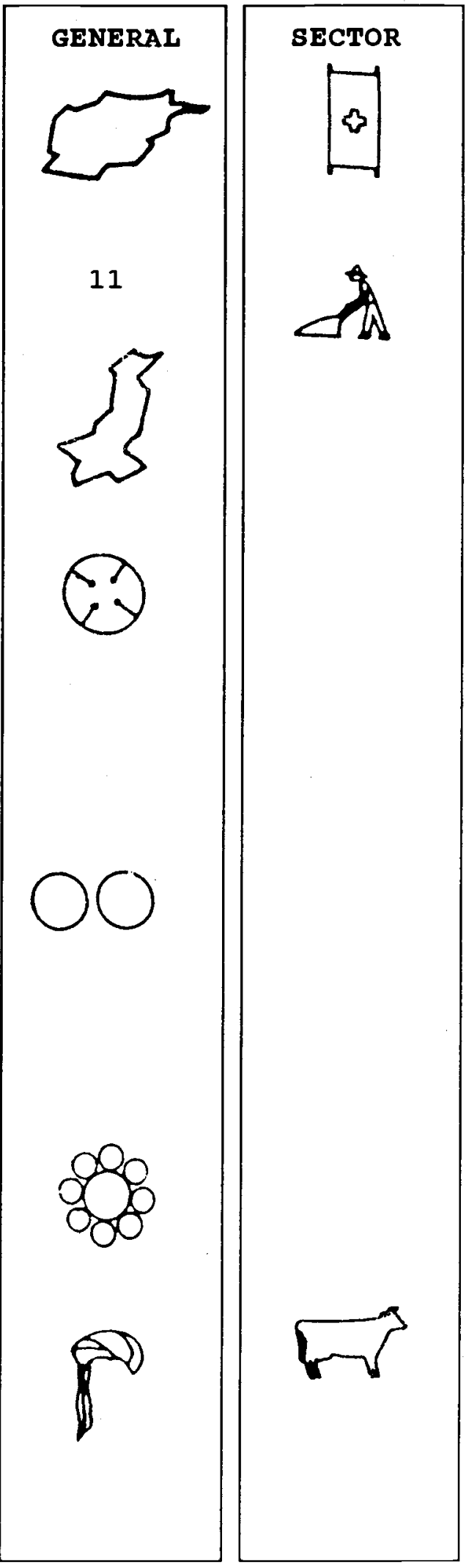

\section{HEADQUARTERS}

MR. KAKO JAN NIAZI

ADENAUER ALLEE - 11

5300 BONN - 1 WEST GERMANY

TEL:

TXL: (0228) 221404

FAX:

\begin{tabular}{|lrr|}
\hline \multicolumn{3}{|c|}{ PERSONNEL } \\
EXPATS & 0 & $0 \%$ \\
AFGHANS & 122 & $100 \%$ \\
PAKISTANIS & 0 & $0 \%$ \\
TOTAL & 122 & \\
\hline
\end{tabular}

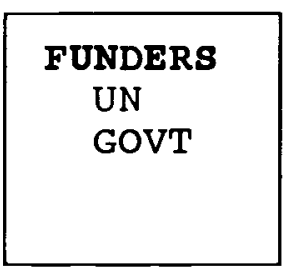

$$
\begin{array}{|l}
\hline \text { B } \\
\hline \text { A } \\
\mathrm{P} \\
\mathrm{T} \\
\hline
\end{array}
$$

$\mathrm{B}$
$\mathrm{A}$
$\mathrm{P}$
$\mathrm{T}$
50




\section{THE GERMAN AFGHANISTAN}

FOUNDATION is a non-governmental, non-political humanitarian organization established simultaneously in the Federal Republic of Germany and Pakistan in 1986. GAF is basically involved in crossborder projects, with some veterinary services for Afghan refugees at the border areas and a veterinary training project for young Afghans in Peshawar.

Although the organization is primarily assisting in the agricultural sector, it is also rendering medical assistance through clinics and a hospital. A maternal and child health program and a vaccination project are also implemented.

The paravet training course, established in 1989, in Hayatabad, Peshawar, has so far trained 88 young Afghans. Forty percent of these paravets have been employed at various veterinary stations at the border areas in Pakistan in various provinces inside Afghanistan.

It is planned that the remaining $60 \%$ be employed at veterinary stations inside Afghanistan in 1990, to assist repatriation. At present, 40 Afghans are undergoing training. It is further planned to train an additional 80 by the end of 1990 . Three veterinary centers for refugee livestock are functioning at the Pakistan border areas.

In Afghanistan, GAF is implementing six veterinary projects and five medical projects - including a hospital - in Bamyan. Additionally, a maternal and child health training project, a vaccination program and three crop-production projects are operating in various provinces. The result of one of the agricultural projects in Zurmat District, Paktia, has been highly significant; one-hundred hectares of land have been cultivated with potatoes and maize. The yield data recently received shows $3,040 \mathrm{mt}$ of potato yield against $52.51 \mathrm{mt}$ of seed sown and $548 \mathrm{mt}$ of corn yield against $5.2 \mathrm{mt}$ maize sown.

GAF intends to focus even more intensively on the agricultural sector (veterinary, crop production, irrigation systems, etc.). Hence, 14 more veterinary centers and one more medium-scale crop production project are planned, to become functional in 1990. No expansion of activities with respect to medical projects is foreseen.

The Foundation implements its projects through whatever infrastructure may be available in the targeted area, i.e., shuras, commander, village elders, etc., and with provision that the population makes maximum utilization of the project.

Funding :UNDP, UNHCR, UNICEF, some bilateral donors and public donations in FRG. 


\section{LOCAL ADDRESS}

$P$ O BAG 6

QUETTA PAK

AHMADZAI COLONY

SARIAB ROAD QUETTA, PAK

TEL: 081-40002

TXL: 7884 CTO QT PK ATTN O.H.I

FAX:

MR. PASCAL SIMON

MS. ELISABETH PIRNAY

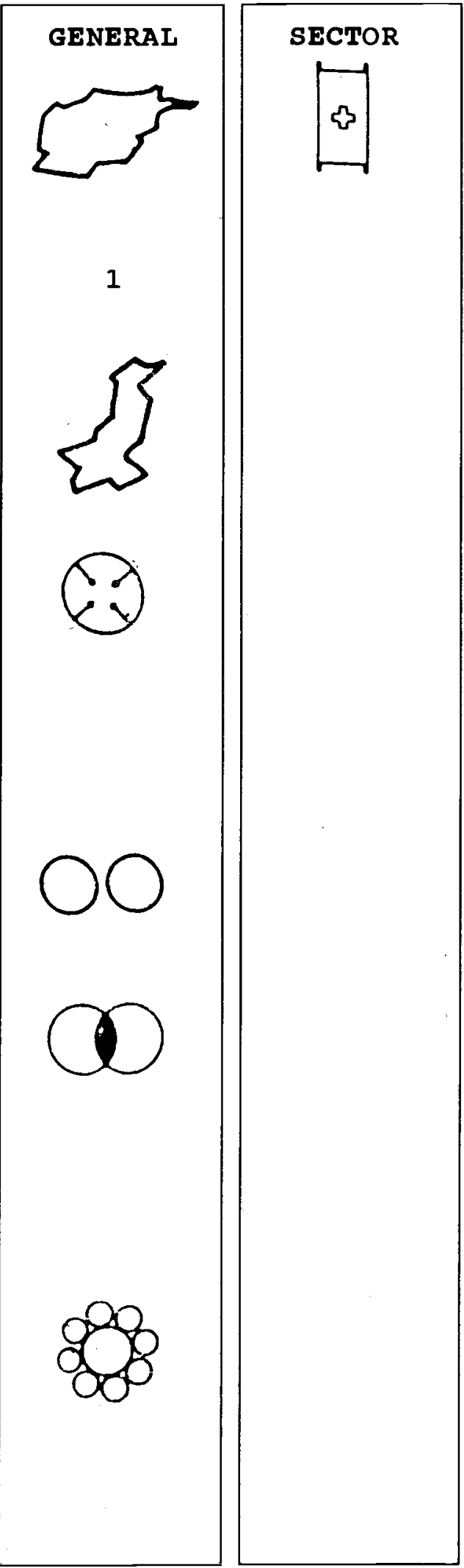

HEADQUARTERS

MR. DOMINIQUE GERARD

111 AVENUE CLAYS

1030 BRUSSELS BELGIUM

TEL: (2) $735 \quad 20 \quad 08$

TXL: 26962 BARA B ATTN.O.H.I.

FAX:

\section{$\mathrm{E}$} EXPATS AFGHANS PAKISTANIS TOTAI

PERSONNEL

$\begin{array}{rr}7 & 7 \% \\ 85 & 88 \% \\ 5 & 5 \% \\ 97 & \end{array}$

FUNDERS
UN
GOVT
PRIV

SECTOR

$r$

\begin{tabular}{l}
\hline $\mathrm{B}$ \\
$\mathrm{A}$ \\
$\mathrm{P}$ \\
$\mathrm{T}$ \\
52
\end{tabular}

$$
\text { P }
$$


HANDICAP INTERNATIONAL (HI) was created in 1985, largely at the initiative of UNHCR, and out of the awareness that few services existed for handicapped people in Baluchistan, and the large number of disabled persons among the Afghan refugee population.

One of the priorities of the program is to promote the autonomy of the center through the training of its local staff. To this end, $\mathrm{HI}$ has achieved the following: the technicians have acquired the technical expertise necessary to manufacture orthopaedic devices of a high standard, using appropriate technology; the physiotherapist assistants were taught to consult the patients in order to identify their problems and provide appropriate treatment and devices. Most technicians and physiotherapist assistants are now able to teach new workers and students. (HI has also provided physiotherapy training sessions for nurses working in various local hospitals).

Using the Quetta Center as a base, a mobile team of local physiotherapist assistants makes monthly field trips to refugee villages around Baluchistan; nineteen are currently visited. A specific network of Afghan outreach workers is working in the various camps, to identify the handicapped population most likely to benefit from the services of Handicap International, and to refer them to these monthly consultations. Some patients are treated in the camps and followed up by the outreach workers, while others are directed to the Center for extended treatment. Between September 1985 and June 1989, 9,100 new patients were registered, and 9,000 gait aids and orthopaedic devices have been made. Recently the Baluchistan Government has opened an Orthopaedic, Prosthesis and Physiotherapy Center in Quetta for Pakistani disabled. Handicap International has been requested to become Technical Consultant in its implementation.

In December 1988, an HI team, consisting of an expatriate physiotherapist, an Afghan orthopaedic technician and an Afghan physiotherapist assistant - trained at the Quetta Center - set up a small center at Zindajan, Herat Province. They are working in close cooperation with an MSF surgical hospital. The team is currently training nine local orthopaedic technicians and five physiotherapist assistants, working in various local hospitals. The aim of this center is to manufacture prostheses, due to the large number of amputees. Later, the program will possibly be extended to manufacture other devices, such as braces and orthopaedic shoes, wheelchairs and walking aids.

An Orthopaedic and Physiotherapy Training Centre for Afghan People will be established in Quetta to train Afghan orthopaedic technicians and physiotherapist assistants.

Funding: UNHCR and WHO. 
LOCAL ADDRESS

G P O BOX 912

UNIV TOWN PESHAWAR, PAK

34-E S J AFGHANI ROAD

UNIV TOWN PESHAWAR, PAK

TEL : 41530

TXL:

FAX:

DR. LORENZ L. GOSER

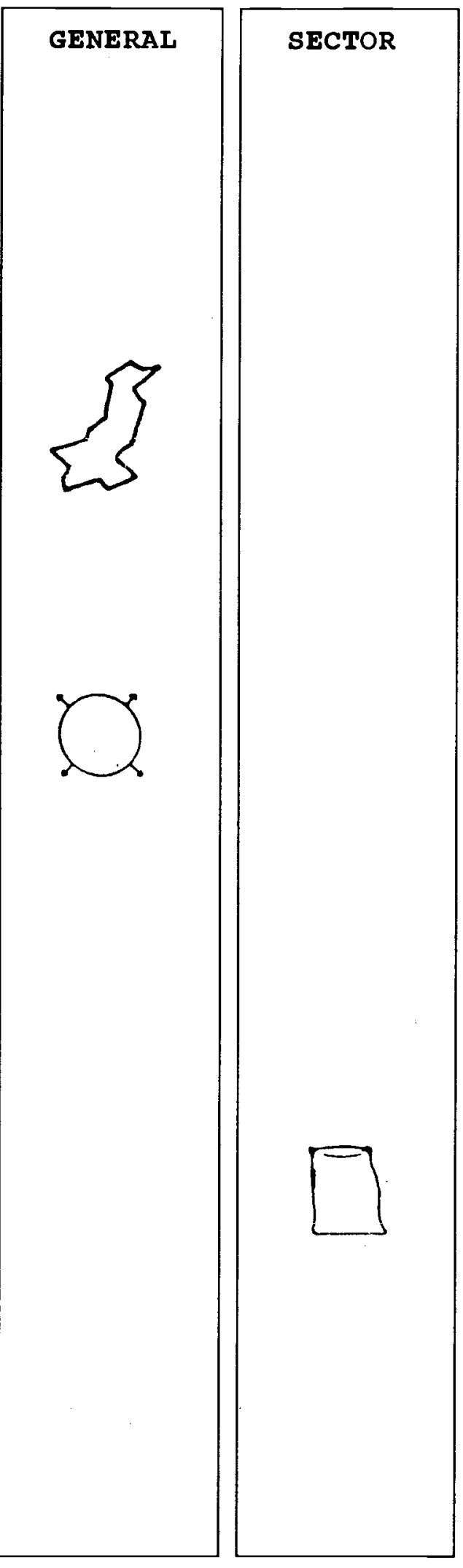

GOVT

PRIV
BUDGET (US \$) 1987

AFGHANISTAN

PAKISTAN

TOTAL

$1,388,888$

$1.388,888$
1989

1990

1988

$1,664,816$

$1,664,816$

$2,068,560$

$2,068,560$

$2,471,435$

$2,471,435$ 
HELP was founded in 1981, to assist Afghan refugees in Pakistan. A funding agency, HELP has provided support to refugee projects through the various independent, humanitarian Afghan relief organizations, as follows:

1. Union Aid for Afghan Refugees was the first and remains the main partner of HELP. Union Aid operates: a 50-bed hospital and seven Basic Health Units in Barakai-Camp near Swabi, six in Mundapul and 11 in various other refugee villages, along with two well-equipped laboratories. Twelve "mechanical-cows" and six vehicles bring 18,000 liters of milk daily for distribution to children not served through the BHU. In Kachagarhi 120 boys are trained yearly in five different handicrafts.

2. Afghan Health and Social Assistance Organization operates a Child Health Center in Peshawar, where 400 patients are examined daily in its OPD, and 20 beds are provided in IPD. The expenses are jointly shared by HELP and Help the Afghans.

3. Dental Clinic for Afghan Refugees in Peshawar is well equipped with six dental chairs, $x$-ray facilities and laboratory. Two female doctors care for the women. In 1988 about 8200 dental-prostheses were provided and 31,000 patients treated. All costs are paid by HELP.

4. Psychiatry Center for Afghans serves those many refugees who suffer from post-traumatic disorders due to war experiences and hardships as refugees in the camps. The Psychiatry Center is fully sponsored by HELP. More than
19,000 patients ( $39 \%$ female) were seen in 1988.

5. Afghan Obstetrics \& Gynecology Hospital is the only such hospital for the one million Afghan refugee women, a great many of whom must, therefore, come from great distances. Among other sponsors HELP covers about $20 \%$ of the expenses of this facility.

6. Islamic Organization of Afghan Women provides courses in sewing and embroidery and a kindergarten for small children.

7. German Aid Clinic in Quetta cares for mainly Hazara refugees and includes a medical outpost and school in Surkhab Camp.

8. In 1988 , orthopaedic surgery was provided for 50 children with polio, clubfeet and other disabilities.

9. Occasional donations and assistance is provided to other organizations; for example, quilts for Chitral, tents for schools, etc., and assistance was and will continue to be given to new arrivals.

10. Assistance to new arrivals was provided immediately after the appeal from the Home Secretary and the Commissioner A.R. in April 1989. This assistance will be continued, mainly providing fooditems.

Funding: German government and private donations. 
LOCAL ADDRESS

$P$ O BOX 819

UNIV TOWN PESHAWAR, PAK

5C-2 ABDARA ROAD

UNIV TOWN PESHAWAR, PAK

TEL: 44053

TXL:

FAX:

MR. JASPER J. VAN BILDERBEEK

(REPRESENTATIVE)

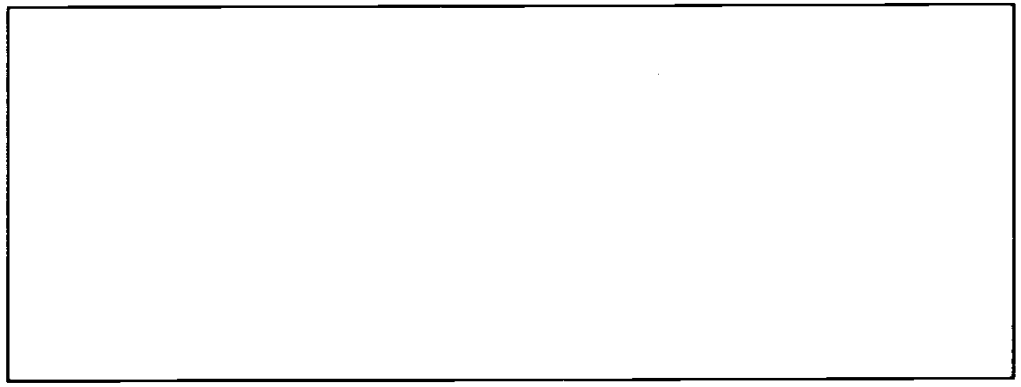

GENERAL

SECTOR

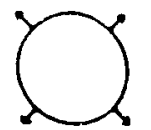

HEADQUARTERS

MR. WILLINGE

BINCKHORST LAAN 309

2516 BC DEN HAAG (HAGVE) NETHERLANDS TEL: $070-836641$

TXL: 32665 WILMA NL FAX:

\begin{tabular}{|lrr|}
\hline \multicolumn{3}{|c|}{ PERSONNEL } \\
EXPATS & 1 & $100 \%$ \\
AFGHANS & 0 & $0 \%$ \\
PAKISTANIS & 0 & $0 \%$ \\
TOTAL & 1 & \\
\hline
\end{tabular}

\section{FUNDERS}

GOVT

PRIV

\section{BUDGET (US \$) 1987}

AFGHANISTAN

PAKISTAN

TOTAL
274,884

274,884
1988

421,753

421,753
1989

372,184

372,184
1990

355,306

355,306 
HELP THE AFGHANS FOUNDATION (HAF) was founded in 1984 as a relief agency for the victims of war in Afghanistan, especially women and children. HAF does not implement projects itself but funds relief organizations which are predominantly working in health care.

In 1986, HAF began supporting the Children's Clinic of the Afghan Health and Social Assistance Organization in Peshawar. (Since mid 1987, the Clinic has had the co-sponsorship of HELP of West Germany on a $50 / 50$ basis.) In 1988, HAF began to fund 2 Basic Health Units, along with a milk distribution project in Aza Khel, through AHSAO. These BHU's supply basic preventive and curative health care to Afghan refugees through an active vaccination program, malaria control, health education, and a Maternal and Child Health Project.

The Maternal and Child Health Project involves antenatal care, assistance in deliveries, an under-two clinic and a training program for Traditional Birth Attendants (TBAs) - co-sponsored by SCA and UNICEF. The under-two clinic has an active case detection and treatment program for malnourished children, which includes frequent home visits and the supervised preparation of meals with the mothers.

Besides these on-going projects, HAF sponsors agencies on a more incidental basis, e.g., the construction of a primary school in Munda camp and food distribution in Afghanistan.
Funding: Dutch Government, Stichting Vluchteling, Liliane Fund. 
LOCAL ADDRESS

$\mathrm{P} O \mathrm{BOX} 880$

UNIV TOWN PESHAWAR, PAK MATTA HOUSE JEHANGIRABAD

UNIVERSITY ROAD PESHAWAR, PAK

TEL: 42524

TXL:

FAX: 42544

MR. AHMAD KHADR

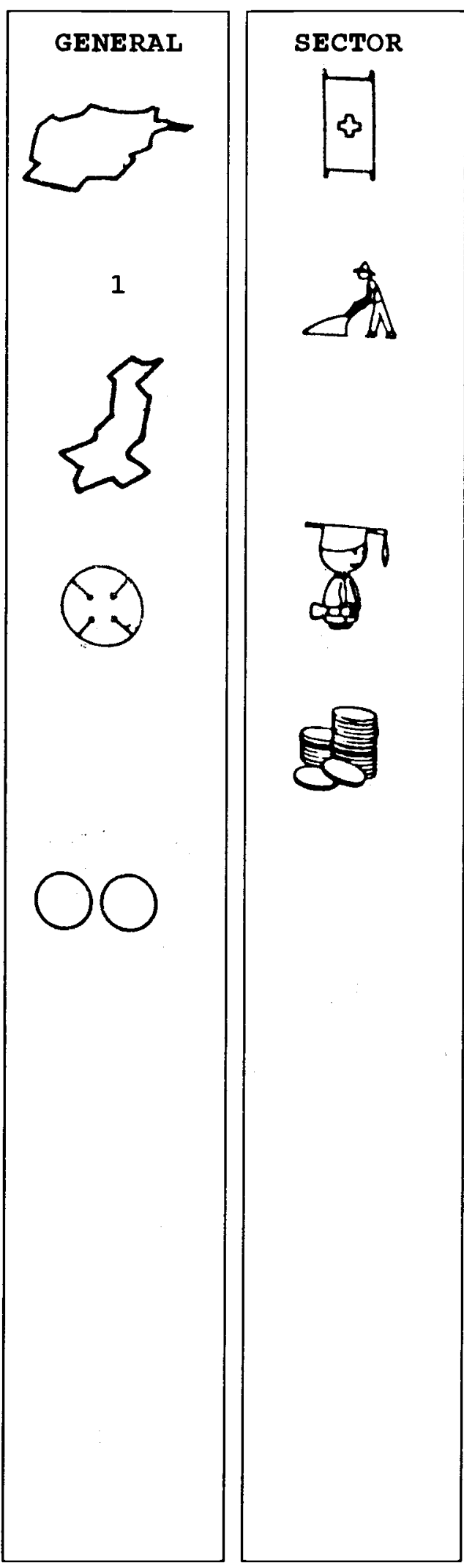

HEADQUARTERS

MR. ABU NAZIR

BOX 3984, STATION C

OTTAWA CANADA KIY $4 \mathrm{P} 2$

TEL: (613) 234-4585

TXL:

FAX: (613) 234-4775

\begin{tabular}{|lrr|}
\hline \multicolumn{3}{|c|}{ PERSONNEL } \\
EXPATS & 5 & $3 \%$ \\
AFGHANS & 134 & $91 \%$ \\
PAKISTANIS & 8 & $5 \%$ \\
TOTAL & 147 & \\
\hline
\end{tabular}

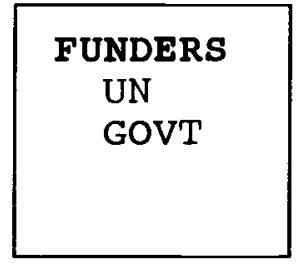

$$
\begin{aligned}
& \text { BU } \\
& \text { PF } \\
& \text { TO }
\end{aligned}
$$

AFGHAN ISTAN

PAKISTAN

TOTAL
BUDGET (US \$)
1988

104,554

716,981

821,535
1989

827,913

515,670

$1,343,583$
541,324

612,798 
HUMAN CONCERN INTERNATIONAL (HCI) is a charitable organization headquartered in Ottawa, Canada.

Human Concern International, Peshawar has been carrying out a variety of projects for Afghan Refugees since 1985 in NWFP and inside Afghanistan. It affords financial help to Afghan orphans, educates and trains them in certain trades to enable them to earn a livelihood for themselves and their dependents. Since 1987, HCI has operated rehabilitation programs inside Afghanistan.

A school is provided for Afghan children up to the seventh grade. Hundreds of students are studying there. These students are provided with stationery and books needed for their respective classes. Lunch is served daily to about 375 orphaned students.

The Vocational Centre at Akora Khattak provides training facilities to Afghan boys to learn carpet making, the construction of leather hand bags and shoes, tailoring, carpentering, etc. These products are then exported to the Middle Eastern countries, thereby earning foreign exchange for Pakistan as well as a good income for Human Concern. $\mathrm{HCl}$ also disburses cash money to orphaned children on a monthly basis.

The mother and child care project has four Basic Health Units in Akora Khattak, where medical facilities are provided to Afghan women and children as well as training to the older and middle-aged women on the Traditional Birth Systems. Due to a lack of education, Afghan women generally will not avail themselves of services at a gynaecological centre. They prefer to give birth through traditional dais. HCI undertook the training of Afghan women in traditional birthing methods, and are awarding certificates to the second successful group of TBA's.

Human Concern carries out irrigation and agricultural schemes inside Afghanistan, and successfully completed one such project in Logar province on 31 July 1989. A Crop Production Program (Farm Power Machinery), is being implemented in the same province and is expected to be completed by the end of October, 1989. Surveys relative to agricultural, irrigation, and reconstruction needs were carried out in Logar, Ghazni, Wardak and Kunar provinces.

Currently, Basic Health Units, organized by $\mathrm{HCI}$, operate out-patient departments one day per week with an average of ninety patients per day.

Funding: by private donors in the Middle East, Canada, U.S.A. CIDA, UNHCR and UNDP. 
LOCAL ADDRESS

G P O BOX 488

PESHAWAR, PAK

BUNGALOW 9, MISSION HOSP

DABGARI GARDENS PESHAWAR CITY, PAK

TEL: 213895

TXL:

FAX:

MR. HARRISON MASSEY

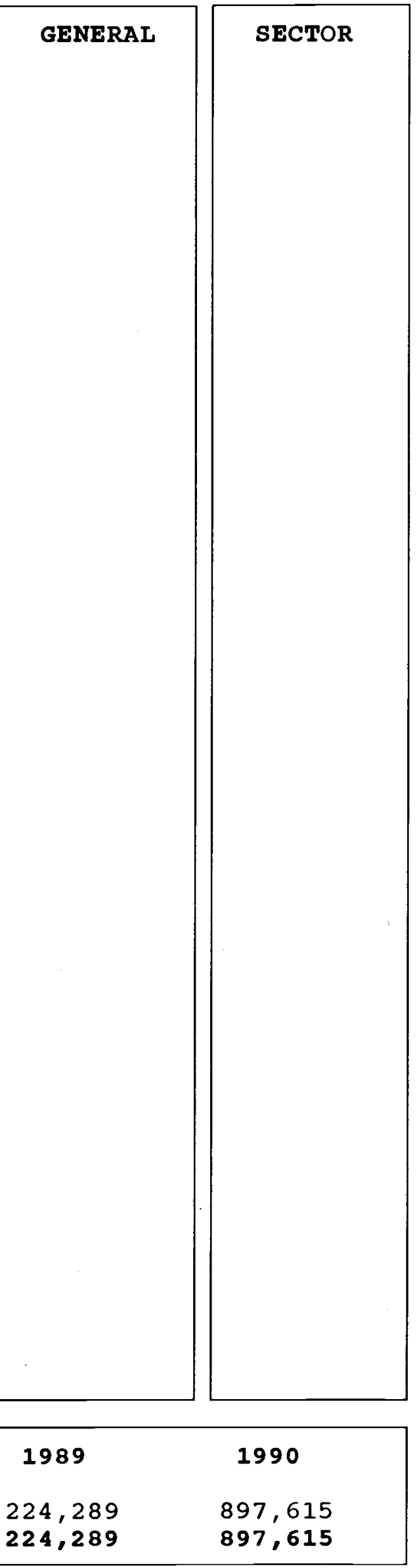

HEADQUARTERS

MR . ASHBER MENGISTU

74 GARDEN ROAD

KARACHI-3, PAK

TEL: 713174

TXL:

FAX:
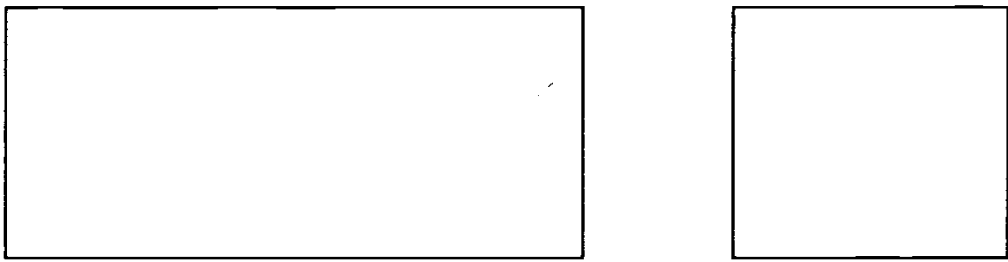

$$
\begin{aligned}
& \text { BU } \\
& \text { AF } \\
& \text { PA } \\
& \text { TO }
\end{aligned}
$$




\section{INTER-CHURCH AID (ICA)}

did not submit any information

NOTE: the data on profile page could not be checked 


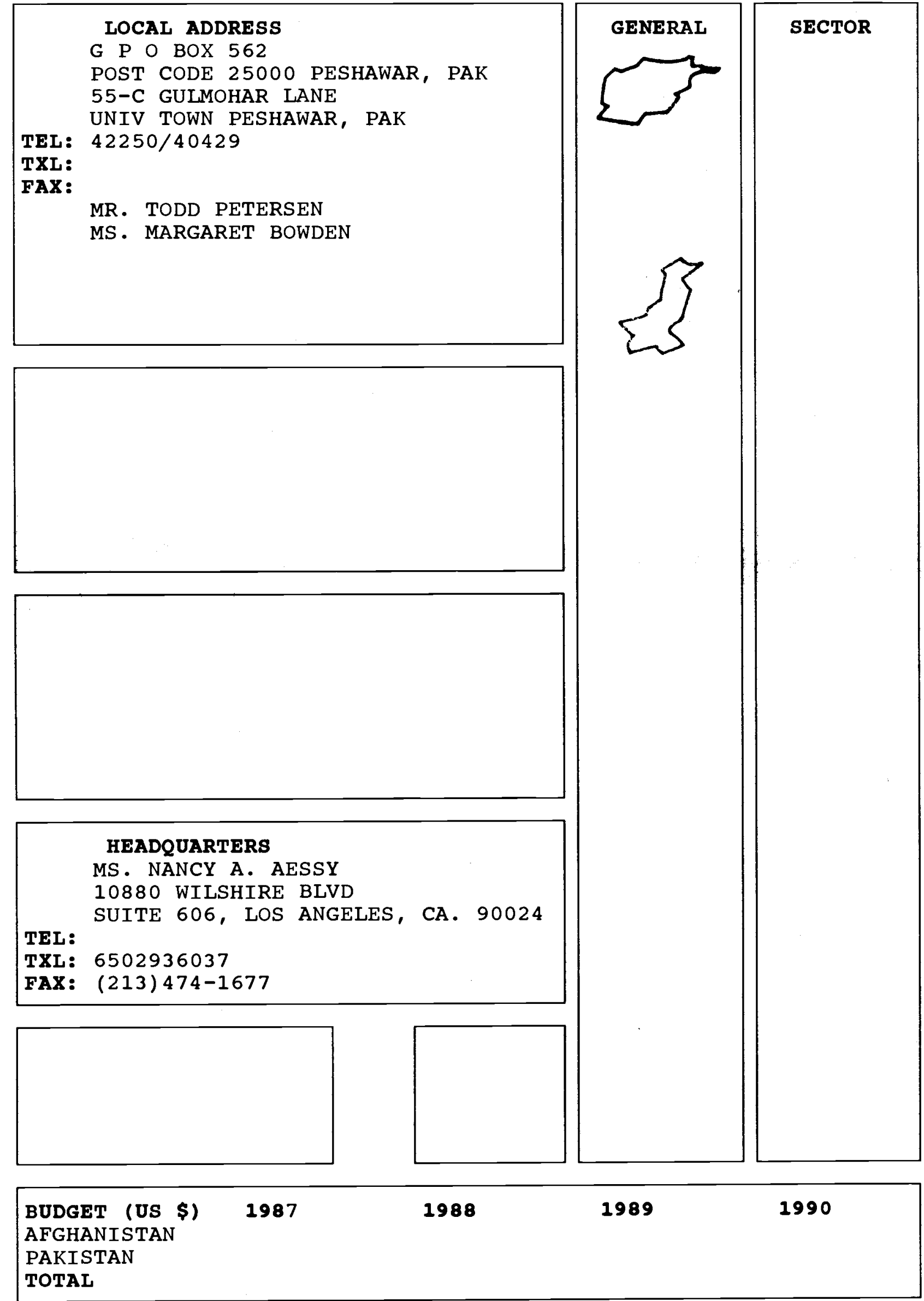


INTERNATIONAL MEDICAL CORPS (IMC)

did not submit any information

NOTE: the data on profile page could not be checked 


\section{LOCAL ADDRESS}

G $P$ O BOX 504

UNIV TOWN PESHAWAR, PAK

41-F S A QAYUM ROAD

UNIV TOWN PESHAWAR, PAK

TEL: $41845 / 41274$

TXL: 52448 IRC PE PK

FAX: $(92-521) 42283$

MR. THOMAS L. YATES

MR. STEVE SEGAL
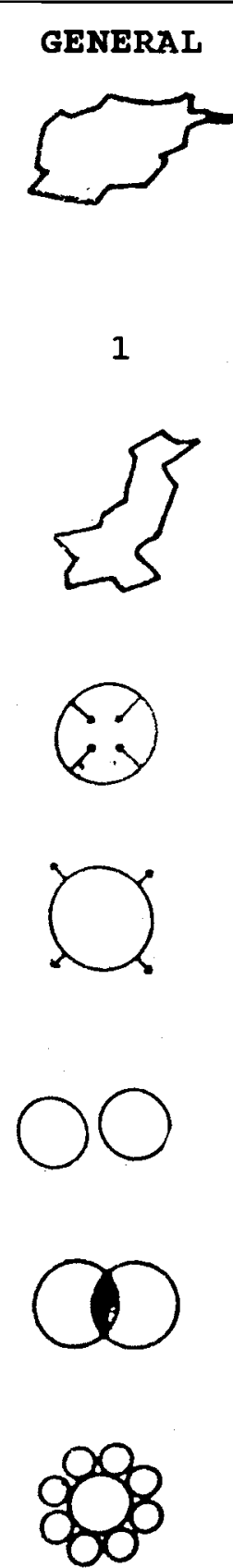

SECTOR
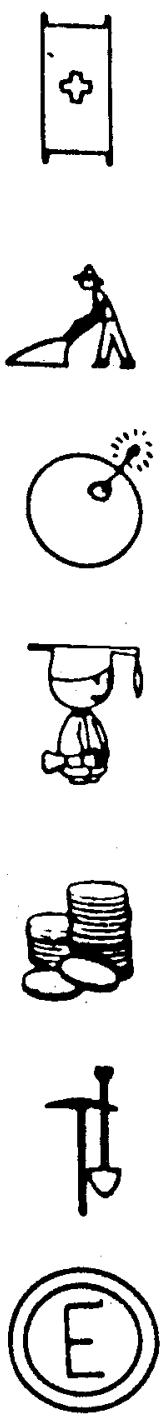

\section{HEADQUARTERS}

MR. ROY WILLIAMS

386 PARK AVE SOUTH

NEW YORK, NY 10016 USA

TEL: 2126790010

TXL: 237611 IRC UR

FAX: (212)689-3459

\begin{tabular}{|lrr|}
\hline \multicolumn{3}{|c|}{ PERSONNEL } \\
EXPATS & 41 & $2 \%$ \\
AFGHANS & 1261 & $79 \%$ \\
PAKISTANIS & 283 & $17 \%$ \\
TOTAL & 1585 & \\
\hline
\end{tabular}

BUDGET (US \$)

AFGHANISTAN $2,604,166$

PAKISTAN

TOTAL
FUNDERS

UN

GOVT

PRIV

\section{8}

$2,838,188$

$6,410,654$

$9,200,000$
1989

$6,897,000$

$4,933,000$

$11,829,000$
1990

$11,143,000$

$4,919,000$

$13,724,000$ 
For more than fifty years, the I N TER NATIONAL RESCUE COMMITTEE (IRC) has been helping people from all over the world who have fled persecution and violence in their homelands. Currently, IRC has programs in Thailand and Hong Kong, in the Sudan and Malawi, in Costa Rica and El Salvador, in Europe, and in Pakistan.

The program in Pakistan has been assisting refugees in the fields of health, education and self-reliance since 1980. IRC is now also implementing programs in Afghanistan; it is involved in seven major program areas:

1. Self-Reliance: These programs help refugees support themselves by enhancing development work in the camps and providing paid employment. Over 20,000 families directly benefit through employment and increased agricultural production.

2. Medical: The first of the IRC relief programs in Pakistan, the Medical Program, began in July 1980, with two medical teams. It now operates 12 health units in 12 refugee villages and receives over a half million patient visits yearly. In all camps where health units exist, there is an outreach program, a dental clinic, a medical lab and a sanitation program.

3. Health Education Resource Center: The Center produces booklets, silkscreened posters, flip charts, slide shows and audio tapes on health topics in Dari and Pashto. The resource library contains materials in English, Dari, Pashto and Urdu.

4. Mine Awareness: The purpose of the program is to teach the more than 3.5 million Afghans in Pakistan about the dangers, the detection, and the avoidance of land mines. The program trains
Afghan teachers and produces educational materials.

5. Rural Assistance Program: The goal is to assist war-affected Afghans who have remained in Afghanistan or who are returning, through rural and agricultural assistance projects.

6. Education: There are 14 IRC education programs, reaching more than 20,000 refugees; they assist Afghans who aspire to be future leaders and managers.

7. Rehabilitation Program: This program addresses the needs of over 190,000 refugees served by IRC in the Kohat/Hangu area of Pakistan, in the process of repatriation by identifying and funding rehabilitative projects in the refugees' home provinces.
Funding: UN agencies, US and Canadian Governments, Bernard Foundation, Van Leer Foundation, Refugees International, Stichting Vluchteling, Norwegian Refugee Council/Norwegian Church Aid, Operation Day's Work, Donner Foundation, and private donors. 


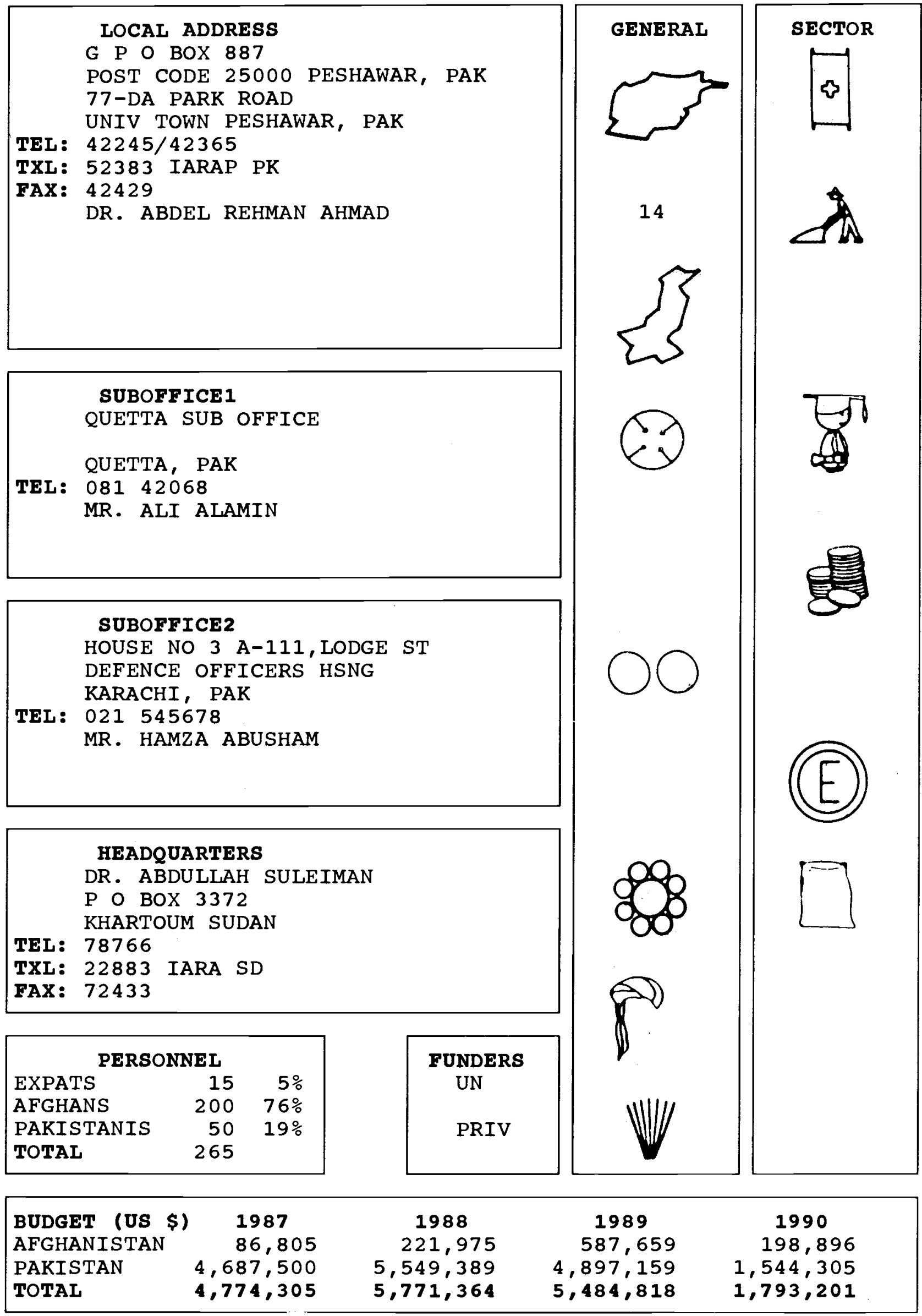


The ISLAMIC RELIEF AGENCY (ISRA) is an international relief agency offering assistance irrespective of caste, creed, religion or race to those affected by natural disasters and physical disruption or foreign aggression, and who are compelled to take refuge in other countries. ISRA maintains its headquarters in Birmingham and its regional centers function throughout the world, with Peshawar being the regional office for Pakistan.

One primary focus of ISRA is to conduct field studies in drought-and disasteraffected areas and present their findings to international relief and charity organizations and philanthropists around the world to enable them to plan and create projects that are effective and appropriate to the needs of the target populations. The Agency also places a strong emphasis on providing vocational training to refugees to allow them the possibility of generating income. Afghan refugees have been provided with training courses in tailoring, lathe operation, welding, motor mechanics, and carpentry.

In addition to training of a more vocational character, the Agency has undertaken training in the areas of teaching, office management, and survey and mapping. Along with its development of projects in the agricultural sector, ISRA is also involved in the medical sector, in which it has launched an ambitious program for the establishment of dispensaries, medical clinics, mother and child centers, immunization centers, and T.B. and malaria control programs.

Funding: UNDP and self finance. 
LOCAL ADDRESS

$U \mathrm{P} O$ BOX 847

UNIV TOWN PESHAWAR, PAK 3-C II CIRCULAR ROAD

UNIV TOWN PESHAWAR, PAK

TEL: 44350

TXL:

FAX:

DR. SHAWALI WALIZARIF, MD

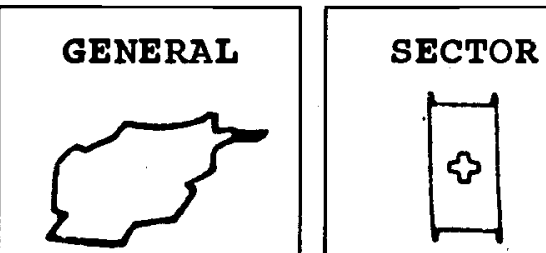

2

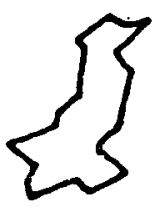

8

$\bigcirc \bigcirc$
HEADQUARTERS

DR. YUJI SATO, MD

FUKUOKA YMCA, 1-10-24

SANWA BLDG 4F, TENJIN CHUOKU, FUKUOKA TEL: 0927817410

TXL:

FAX:

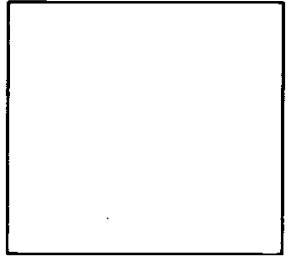

1988

1989

39,177

34,280

73,457
40,149

40,149
1990

23,375

70,126

93,501
PAKISTAN

TOTAL
22,476

22,476 
JAPAN - AFGHAN MEDICAL SERVICE (JAMS) was founded in October 1986 as Afghan Leprosy Service. In the beginning, it operated as an extension program for leprosy control in NWFP. The service was in response to the influx of Afghan refugees and an increase of registered leprosy patients.

Initially, the activity in the camps was primarily the treatment of skin diseases and leprosy. However, since it was difficult to look after only leprosy patients, leaving aside other infectious diseases, JAMS expanded its activity to include other common diseases, minor and reconstructive surgery, and, at this point, the name of the organization was changed.

The Japan-Afghan Medical Service operates a 20-bed hospital, a daily outpatient department and executes a medical survey program in the camps as a regular outreach program. JAMS has supplied its hospital/clinic with a well-functioning laboratory with modern diagnostic equipment. Expatriate doctors have joined the team and provide education and information to enhance the knowledge and capabilities of doctors and medical assistants.

A medical training course began in January 1989. Eighteen students have since graduated; a number are still under training. In a training program which began in September 1989, medical workers are being trained to work in the rural areas of Afghanistan in the future.

A nutritional survey of mothers and children is the present focus. It is designed to obtain basic information that will make the planning of future health programs more effective.
Funding: $\quad$ solely as a response of the Japanese people, through private donations. 
LOCAL ADDRESS

53 II C GUL MOHAR LANE UNIV TOWN PESHAWAR, PAK 53 II C GUL MOHAR LANE UNIV TOWN PESHAWAR, PAK

TEL: 42234

TXL:

FAX:

MS . ANNE-MARIE SPIESER

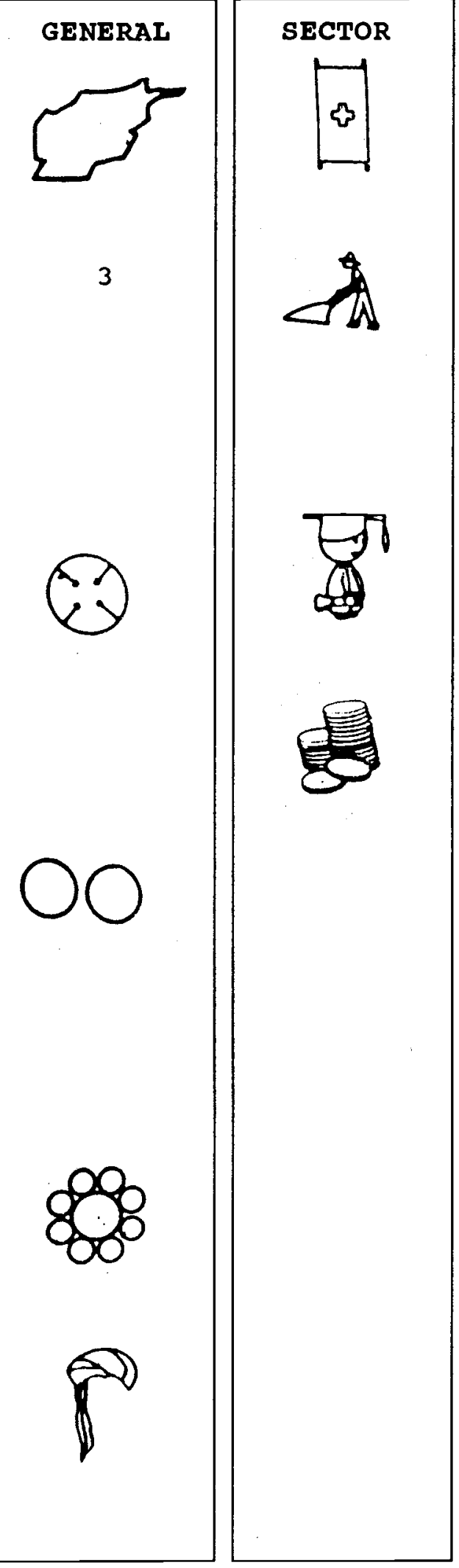

HEADQUARTERS

MS . CAMILLE PERRET

24 RUE DE CHALIGNY

75012 PARIS FRANCE

TEL: $033 \quad 143415560 / 071567$

TXL:

FAX: $033 \quad 1 \quad 45487831$

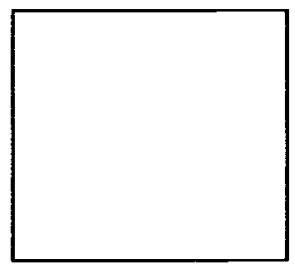

SECTOR

-

$$
\text { s. }
$$

$\begin{array}{llll}\text { BUDGET (US \$) } & 1987 & 1988 & 1989 \\ \text { AFGHANISTAN } & & & 1990 \\ \text { PAKISTAN } & & \\ \text { TOTAL } & & & \end{array}$


MADERA was founded in Paris in August 1988, when it took over the agro-pastoral program initiated by the Bureau International Afghanistan in 1984. MADERA implements programs in two provinces: in Kunar - Weygal and Pech Valleys (extended since 1989 to the areas of Barikot, Asmar, Chigal Darre-Nur); and in Laghman throughout the province.

The general working philosophy of MADERA is to enable the Afghans to manage, by themselves, the reconstruction of their country. MADERA works at two levels: development in the rural communities and the restructuring of the agricultural and veterinary services within a governmental pattern that will allow the implementing and monitoring of programs through a future legal authority. MADERA acts to reinforce existing structures in the field, by setting up specialized and permanent teams, working under the supervision of experienced engineers and veterinarians.

Education, both theoretical and practical, has been an important activity since the beginning. Training, which included management for MADERA Afghan staff, has taken place in the field and in various programs in Peshawar.

The following information is an overview of the projects MADERA initiated up to and including those in 1989, and those planned:

Agriculture: distribution and improvement of wheat seeds, fertilizers and phytosanitarian - 1989, Aliquadari of Kanday (Pech Valley) and Alingar Valley one team each; 1990, Kunar (Asmar and Barikot) and Laghman (Alichang and Tcharbagh) two teams each.

Hydrolic: protection of the banks and stopping the erosion through building of gabions, rehabilitation of the irrigation system - Laghman in Alingar Valley, Kunar in Pech Valley, and Nangrahar in Darre Nur Valley.

Animal Husbandry: clinics and vaccinators - 1988/89, Kunar in Gossalak/Pech, Weygal, Asmar, Barikot. Laghman in Badiabad/Chirkhan (Alingar), Topak, Kalatek (Alichang); 1990, Nangrahar in Darre-Nur, Laghman in Nuristan (Alingar), Dawlat Chah (Alichang), Tcharbagh and in Kunar in Chigal Nichagan (Oluswali Asmar), Naray, and in Kanday (Pech).

Forest: a program of rehabilitation and protection of the forests started in 1989, in Pech, Weygal, Darre-Nur.

Medical: a malarial program will open in 1990, in Laghman.

In the first part of 1990, MADERA will open a sub-office in Chaga-Sarai, to ensure a fully integrated program in Kunar.

Implementing Partners: Swedish Committee of Afghanistan, Norwegian Committee for Afghanistan, Dutch Committee, Aide Medical Internationale 


\section{LOCAL ADDRESS}

$P$ O BOX 919

UNIV TOWN PESHAWAR, PAK

OLD BARA ROAD

UNIV TOWN PESHAWAR, PAK

TEL: 40792

TXL: 52399 USAID PK

FAX: (0521) 42297

DR. WILLIAM D. OLDHAM

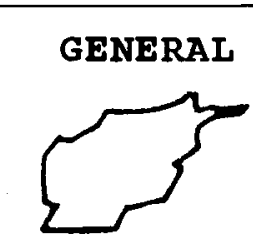

29
SECTOR

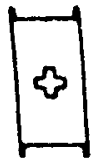

\section{HEADQUARTERS}

MR. PETER HUFF ROUSELLE

165 ALLANDALE ROAD

BOSTON, MASS 02130 USA

TEL: (617) 524-7799

TXL: 4990154 MSH UI

FAX: (617) 5242825

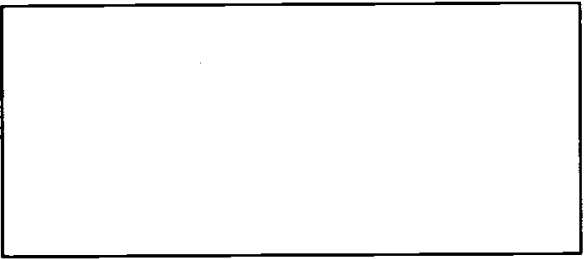

\section{BUDGET (US \$)}

AFGHANISTAN

PAKISTAN

TOTAL
1987

$2,251,157$

$2,251,157$
1988

$5,133,185$

1989

$8,325,171$

$5,133,185$
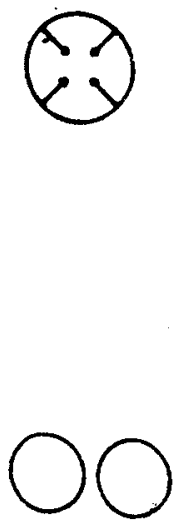

GOVT 
Established in 1971 as a non-profit institution with the broad goal of supporting public health management innovations, MANAGEMENT SCIENCES FOR HEALTH (MSH) currently has nearly 100 professionals employed at its headquarters in Boston and 17 field offices world-wide. During the 1970's MSH worked in Afghanistan helping to strengthen a national program of basic health care through improvements in training, management systems and essential drug supply. One enduring legacy of the project was the training of dais (indigenous midwives) to provide preventive health services to women and children - health workers who have continued work despite the total disruption of the Afghan health infrastructure over the last decade.

Through a co-operative agreement with USAID, MSH is entrusted to provide technical and financial humanitarian assistance to expand and strengthen primary health services inside Afghanistan as rapidly as possible and to strengthen the capability of Afghan organizations to plan, operate, and monitor these expanded services. To achieve the objectives of the Health Sector Support Project, MSH designed and is implementing Basic Health Worker training centers, Basic Health Posts, clinics and hospitals; immunization and preventive medicine campaigns, and mother and child health programs. Afghan institution building is an integral part of the project.

Since the inception of the program in October 1986, over 1400 Basic Health Workers have successfully completed the three-month course and were deployed inside Afghanistan to set up health posts in each of the twenty-nine provinces. To train BHWs, two Pakistan-based and two Afghanistan-based training centers have been established. Two additional centers for Afghanistan are planned. Nearly
30,000 Mujahedeen were given training in basic first aid treatment, and 10 immunization teams have been sent inside to inoculate women and children. The Project is also supporting a large provincial hospital, three rural hospitals with up to 20 beds and 108 clinics established in twenty-seven of Afghanistan's twenty-nine provinces. More than $\mathbf{4 7 5}$ metric tons of medical supplies have been repackaged into standard and special kits and shipped by caravan to Afghanistan.

An extensive system is in place to monitor MSH-supported facilities and personnel. A base for developing programs for women and children is being established through training of female BHWs, training of dais and the introduction of health services for females and children in MSH-supported clinics and hospitals. An on-going sustainability study will continue to focus on development of health services that are both technically and economically feasible with foreseeable Afghan resources, supplemented by transitional donor inputs.

Funding: USAID, UNICEF and "some NGOs" 
MEDICINS DU MONDE (MDM) is a French-based organization, providing general humanitarian aid, but specializing in medical assistance. MDM was founded in the seventies by Dr. Bernard Kouchner. The organization implements projects on "several continents."

Since the inception of its Afghan involvement in 1980, MDM has implemented medical projects only within Afghanistan. The initial project was in Wardak Province, where Medicines du Monde operated an emergency medical program until 1985 . Since this date, MDM has put in place a central hospital with surgical facilities, $x$-ray equipment and an immunization and T.B. program.

To extend its services to cover a larger area of the province, MDM has built three dispensaries. These dispensaries are supervised by Afghan nurses, trained in the MDM hospital and in Pakistan.

For the last several years, a regional health center has been operating through the combined efforts of a paramedic team of 25 Afghans and French expatriates.

MDM states that its work in Afghanistan has been possible through the relationship it has with Commander Amin Wardak and his mujahedeen, and that since it began its work in Afghanistan, Medicines du Monde has been able to work with all ethnic and political groups.

Funding: European Community, UNagencies, and nongovernmental funding bodies. 
LOCAL ADDRESS

G P O BOX 994

POST CODE 25000 PESHAWAR, PAK

5 AI PARK ROAD

UNIV TOWN PESHAWAR, PAK

TEL: 42251

TXL: 52369 PCO PE PK

FAX: (0521) 42641

MR. DENIS DE POERCK

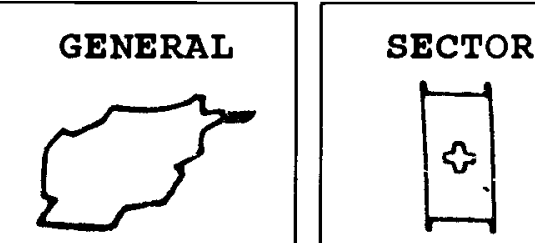

2
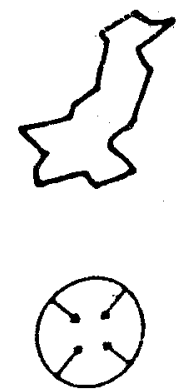

$\bigcirc \bigcirc$

\section{HEADQUARTERS}

DR. GEORGES DALLEMAGNE

24-26, RUE DESCHAMPHELEER

B 1080 BRUSSELS BELGIUM

TEL: $00322-4250300$

TXL: 63607. MSF B

FAX: $00322-4253460$

\begin{tabular}{|lrl|}
\hline \multicolumn{3}{|c|}{ PERSONNEL } \\
EXPATS & 15 & $28 \%$ \\
AFGHANS & 24 & $45 \%$ \\
PAKISTANIS & 14 & $26 \%$ \\
TOTAL & 53 & \\
\hline
\end{tabular}

BUDGET (US \$)

AFGHANISTAN

PAKISTAN

TOTAL

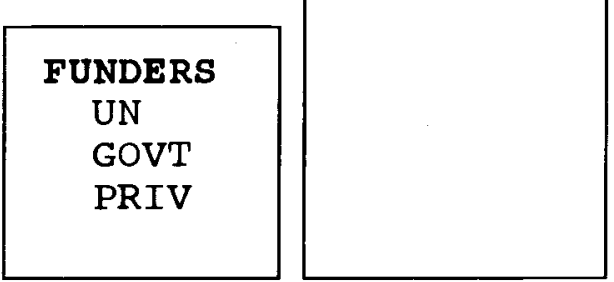

\section{8}

190,895

1989

1990 
MEDECINS SANS FRONTIERESBELGIUM/HOLLAND (MSF-B/H) has four small hospitals in Central Afghanistan staffed with expatriate medical personnel. Only curative care is provided for the moment. Future plans include vaccination, health education and regional coordination/supervision of and asssistance to local health workers. MSF provides for laboratory training of its Afghan personnel in Peshawar, and coordination for similar programs is also promoted.

The projects implemented for Afghan refugees in Pakistan are preventive in nature: the training of male and female community health workers, malaria control, sanitation, immunization, laboratory facility and epidemiologic surveys.

For general information on Medecins sans Frontieres, see MSF (France) on preceding page.

Funding: Dutch and Belgium Government, European Community, UNHCR, WHO and private donations. 


\section{LOCAL ADDRESS}

WHITE HOUSE, 2 PARK LANE

UNIV TOWN PESHAWAR, PAK

WHITE HOUSE, 2 PARK LANE

UNIV TOWN PESHAWAR, PAK

TEL: 42349

TXL: 52490

FAX: 42461

MR. BERNARD CHOMILIER

MS . ELISABETH LARY

MR. PHILIPPE AUDIT

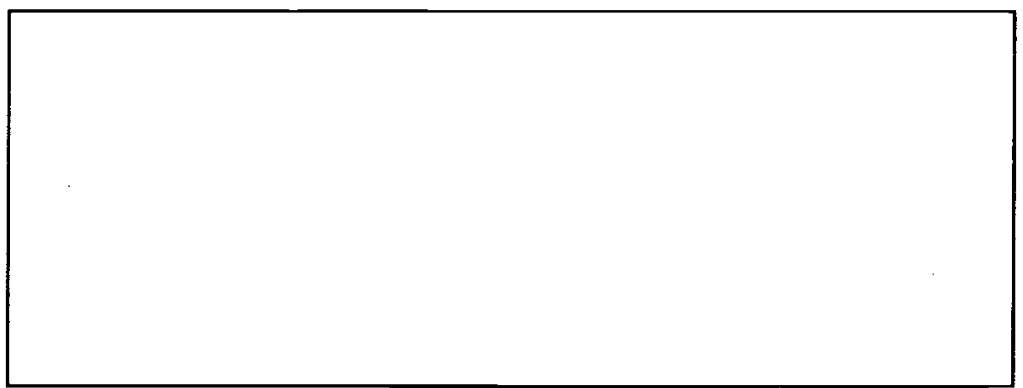

HEADQUARTERS

DR. ROGER VIVARIE

8 RUE SAINT SABIN

75011 PARIS FRANCE

TEL:

TXL: 214360 MSF

FAX: 48066868

\begin{tabular}{|lrr|}
\hline \multicolumn{3}{|c|}{ PERSONNEL } \\
EXPATS & 5 & $23 \%$ \\
AFGHANS & 17 & $77 \%$ \\
PAKISTANIS & 0 & $\%$ \\
TOTAL & 22 & \\
\hline
\end{tabular}

BUDGET (US \$)

AFGHAN ISTAN

PAKISTAN

TOTAL
659,722

165,718

825,440
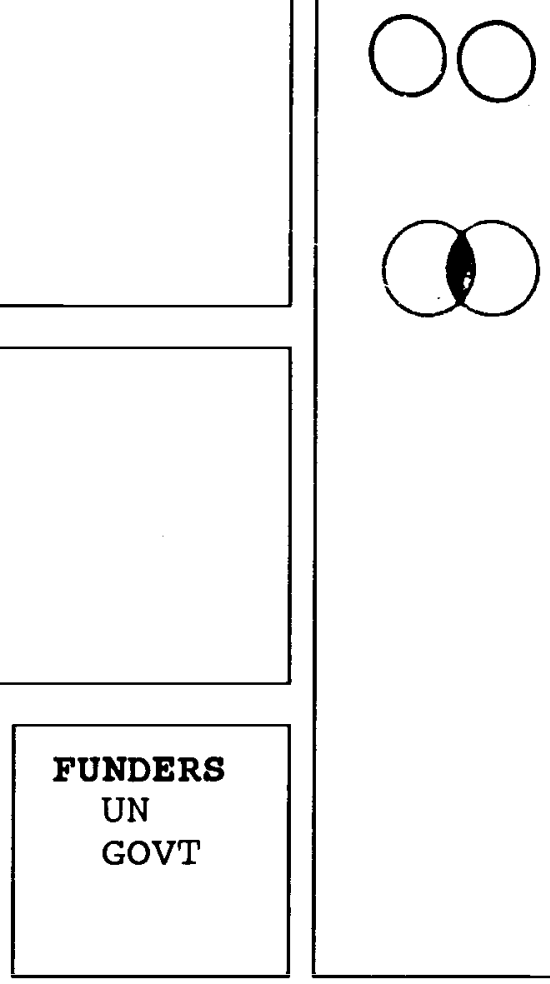

5
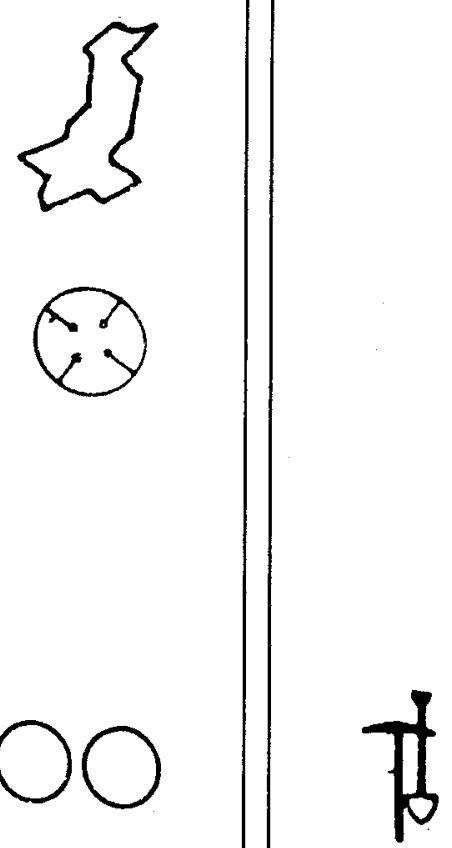

SECTOR
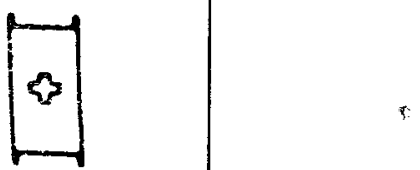

4 
Created in France in 1971, MEDECINS SANS FRONTIERES (MSF) is currently active in some forty countries where each year around 800 doctors and nurses come to the aid of people in distress, as victims of either man-made or natural disasters. MSF also implements post-emergency rehabilitation of health structures and can provide technical advisers to regional or national health authorities. The Belgian and Dutch sections were created in 1980 and 1984 respectively. (See MSFBelgium/Holland)

In Pakistan, programs for Afghan refugees have existed in Baluchistan, Chagar District since 1985, and in the Northwest Frontier Province, Chitral, since 1987. The areas of work in which MSF has been involved are: rehabilitation of Basic Health Units, supervision of BHU staff, sanitation, provision of medicines and salaries, and training of out-reach workers. Examples of results achieved are the training of 600 out-reach workers in Chagar District and the immunization against iodine deficiency in Chitral.

Medecins Sans Frontieres has worked in Afghanistan continuously since 1980 . Areas of work include: construction or rehabilitation of hospitals, training, providing medicines and salaries, immunizations. In Teshkan and Yaftal in Badakhshan and in Jaghori in Hazarajat, Afghan nurses, trained by MSF, are operating the hospital on their own. Successful immunization campaigns for EPI and measles in Ghazni and Badakhshan respectively.

Among the accomplishments of MSF are the following: the rehabilitation of a regional hospital; four expatriate surgical teams have been sent into Afghanistan, achieving more than 1000 operations; one Afghan surgeon and one Afghan anaesthetist have been sent in to work with the French teams. All salaries and operating costs are paid by MSF.

Funding: European Community, WHO, UNICEF and UNHCR. 


\section{LOCAL ADDRESS}

$P$ O BOX 314

QUETTA, PAK

10 ARBAB KARAM ROAD

QUETTA, PAK

TEL: (081) 40142/41953

TXL: 7862 SARAS PK

FAX :

MR. JERRY DINES

MS . MELLA LEITER

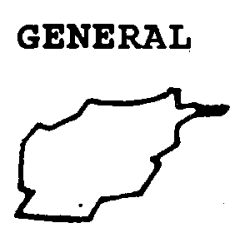

10
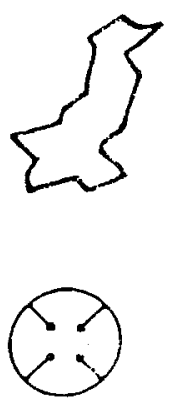

QUETTA, PAK

TEL : (081) 41953

MR. MYRON JESPERSON

MR. DAN FAST

MR. DAVE WALL

\section{HEADQUARTERS}

MR. ELLSWORTH CULVER

3030 SW FIRST AVENUE

PORTLAND, OR 97201 USA

TEL: 242-1032

TXL: 5101002493 MERCY CORP INT

FAX: (503) 223-0501

\begin{tabular}{|lrr|}
\hline \multicolumn{3}{|c|}{ PERSONNEL } \\
EXPATS & 10 & $3 \%$ \\
AFGHANS & 503 & $96 \%$ \\
PAKISTANIS & 5 & $1 \%$ \\
TOTAL & 518 & \\
\hline
\end{tabular}

BUDGET (US \$) 1987

AFGHAN ISTAN

PAKISTAN

TOTAL
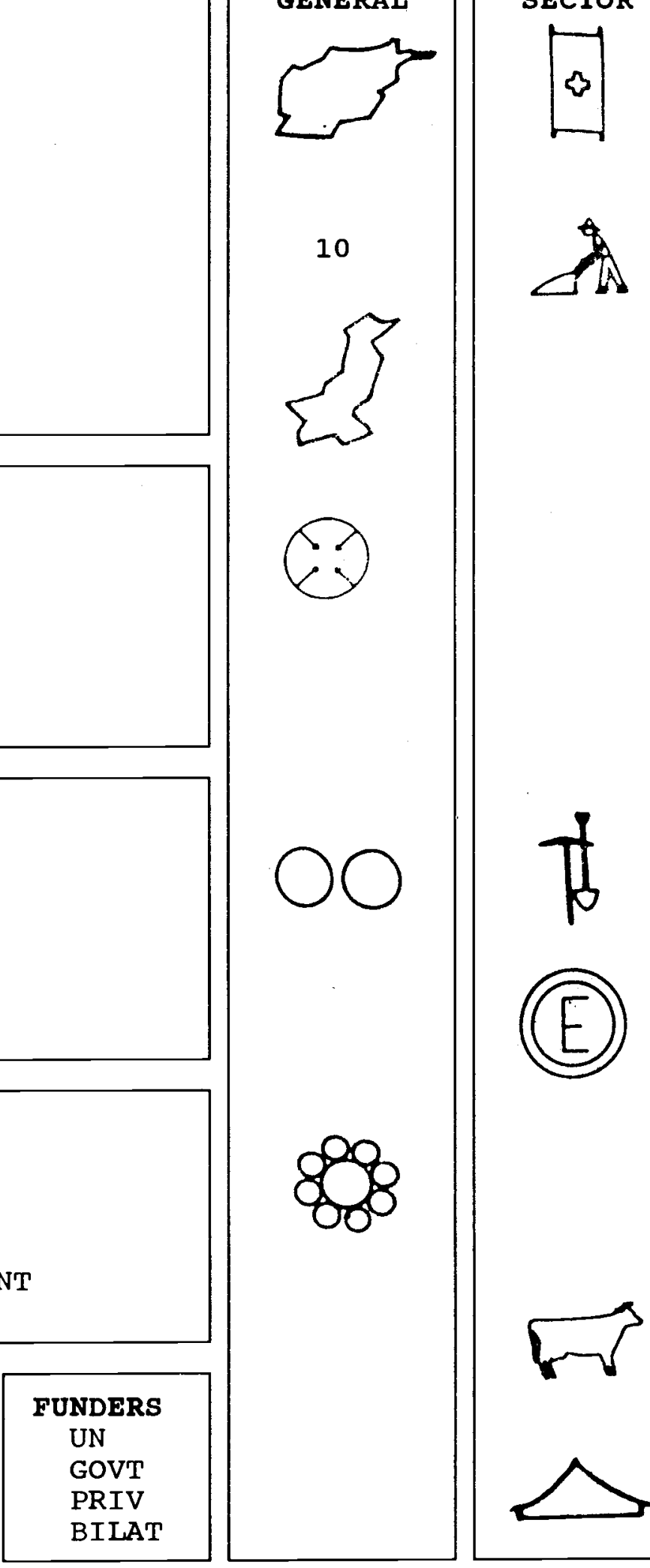

$1,250,840$

503,000
1989

$1,753,840$

1988

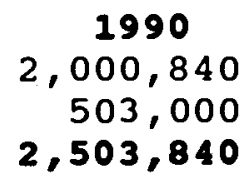


MERCY CORPS INTERNATIONAL (MCI) has a history of involvement in cross-border assistance in war-torn areas. Their first major project was in the Sudan. They are also currently working in Honduras and the Philippines. MCI began implementing its medical work in Quetta in 1986 and its agricultural projects in July 1988.

The medical work in Quetta began in response to the needs of the war-wounded and civilian population in southwestern Afghanistan and to the demands for a health infrastructure for the returning refugee population. The further expansion of MCI assistance to include agricultural programs was to provide related assistance to the same population.

The aim of the medical program is to train students, selected from inside Afghanistan, in either a three-month Basic Health Worker course, or in a more advanced six-month course, offering first aid, nursing skills, preventive and primary health care, as well as training in one of six specialty areas, e.g. $x$-ray.

These trained workers are then sent back to Afghanistan to staff medical facilities that MCI supports. The goal is to establish 36 clinics, with MCI-trained workers in each. Training is on-going and this goal has not yet been reached; however, MCI has already set up 33 functioning facilities. The medical training programs place a strong emphasis on the integration of theory and practical work. All students are taught the specifics of preventative health care and how to provide such care within their own unique cultural and social environment.

The purpose of the agricultural program is to provide rehabilitation to existing villages and facilities in southwestern Afghanistan which have been severely damaged or destroyed by the war. Types of projects in this sector relate to: irrigation, sanitation, improvement in areas of agronomy, animal husbandry, road repair, rebuilding houses and public buildings, and providing discretionary funds to individuals for survival assistance.
Funding: USAID, CIDA, Refugees International - Japan, UNHCR, IRC and in-kind donations. 


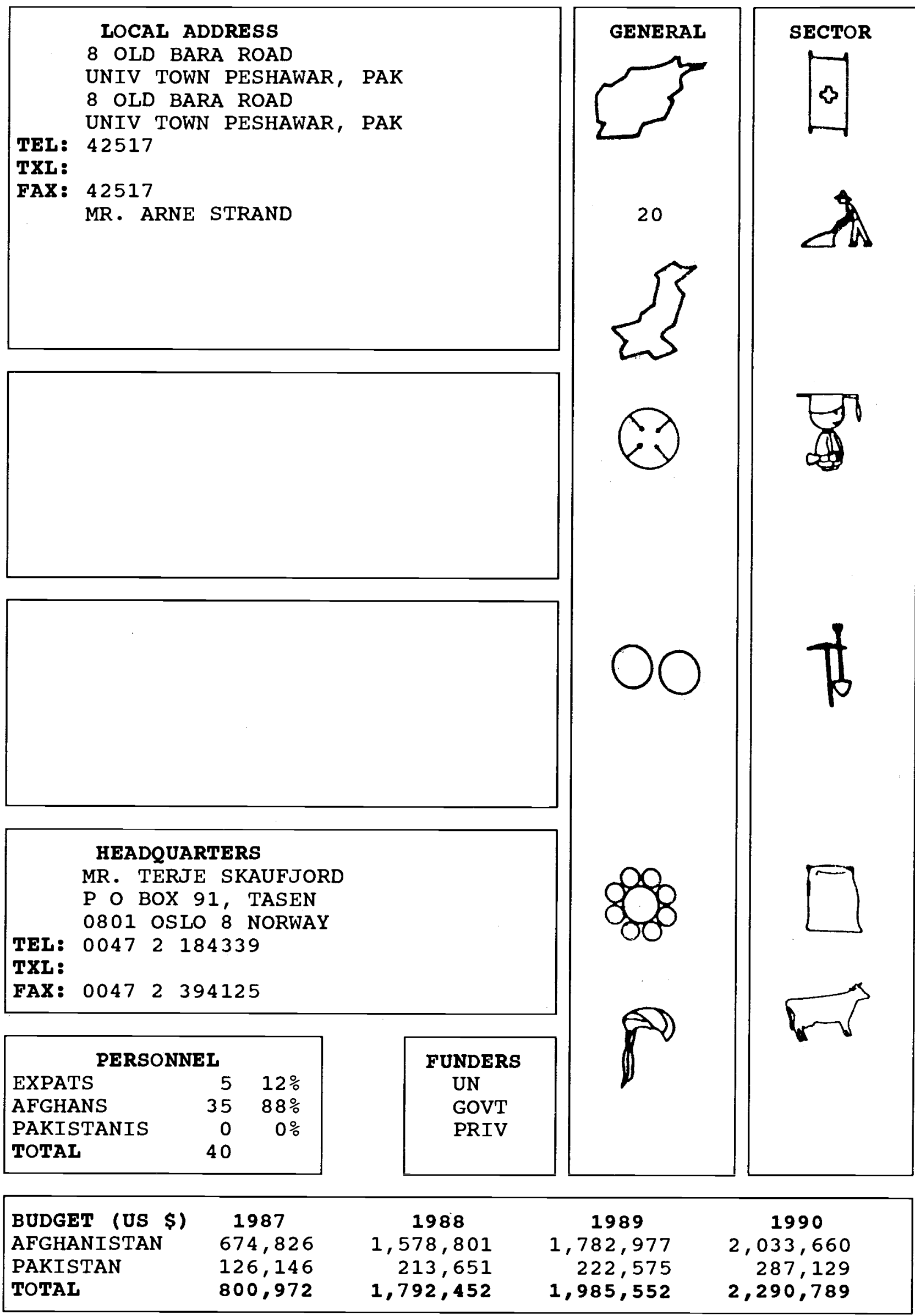


The NORWEGIAN COMMITTEE FOR AFGHANISTAN (NCA) was founded in 1979 in response to the Soviet invasion in Afghanistan. The aim was to get economic support into Afghanistan, and also to provide political support for the liberation of the country. The work started with medical support and a cash-for-food program and has now expanded to include education, immunization, agricultural and reconstruction projects.

In Pakistan, the Committee is supporting girls schools and medical training courses.

In Afghanistan NCA is running various programs in most of the provinces. The work has changed over the last few years from mainly cash-for-food support to agricultural and medical. It is expected that implementation of projects in these fields will increase, and the organization is expanding its Afghan staff to provide closer follow-up of the projects.

NCA is cooperating with several crossborder agencies, but primarily implements its own projects. Projects are implemented through commanders, local doctors and shuras, depending on the situation in the area of operation.

In one area where NCA has been working since 1985 , support has been provided in the following sectors:

1. Education : Support for 43 schools.

2. Agriculture : Improved irrigation systems, supply of seeds and fertilizer and provision of veterinarian services.

3. Health: Support local health systems. Norwegian medical teams are in the area nine months a year; a midwife pilot project is under implementation, and vaccination of children and women is also conducted; construction of a clinic is underway.

Funding: Norwegian Government, UNICEF, and UNHCR. 
LOCAL ADDRESS

51 C PARK AVENUE

UNIV TOWN PESHAWAR, PAK

TEL: $42304-45267$

TXL:

FAX:

MR. KJELL HELGE GODTFREDSEN

(DIRECTOR)

MR. OLAV HALVORSEN (DEPUTY DIREC.)

SUBOFFICE 1

NRC/NCA PROJECT OFFICE

3.B, JAMRUD RD. UNIVE TOWN,

UPO POX 832, PESHAWAR, PAK

TEL : 41129

MR. GUNNAR ANDERSEN

MR. MOHAMMAD KABIR SALIMI

HEADQUARTER1

MRS . EVA DUNLOP (NRC)

P.O.BOX 5856, HEGDEHAUGEN

N-0308 OSLO 3, NORWAY

TEL: 2-603972

FAX: $2-600272$

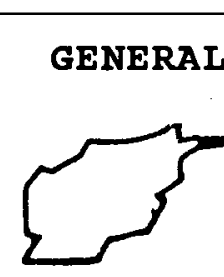

SECTOR
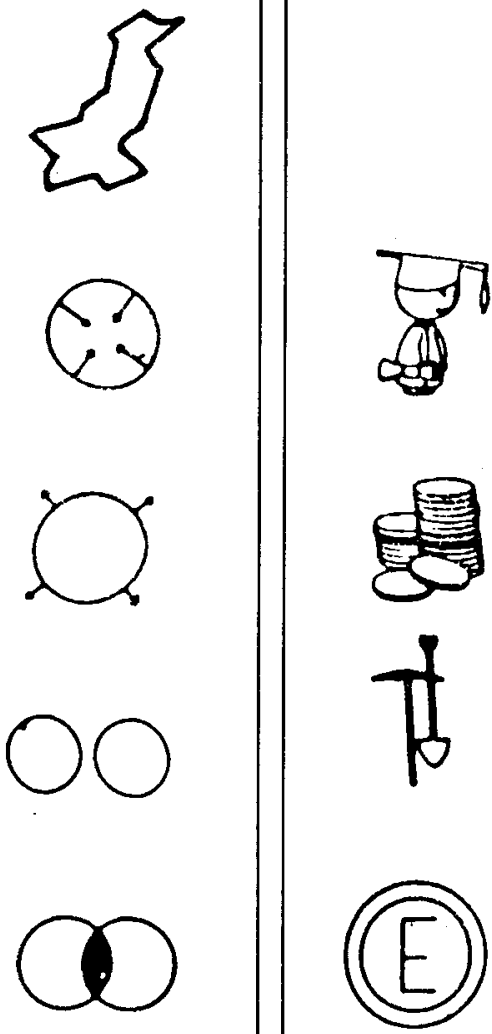

HEADQUARTER2

MR. ARVID OFSTAD (NCA)

$P$ O BOX 5868 HEGDEHAUGEN

$\mathrm{N}-0308$ OSLO 3 NORWAY

TEL: $2-463970$

TXL: 19493CHELPN/72343 NORFU N

FAX: $2-693910$

\begin{tabular}{|lrr|}
\hline \multicolumn{3}{|c|}{ PERSONNEL } \\
EXPATS & 5 & $4 \%$ \\
AFGHANS & 92 & $84 \%$ \\
PAKISTANIS & 13 & $12 \%$ \\
TOTAL & 110 & \\
\hline
\end{tabular}

\begin{tabular}{|l|}
\hline FUNDERS \\
BILAT \\
GOVT \\
UN \\
PRIV \\
\hline
\end{tabular}

$$
\begin{array}{ll}
\begin{array}{l}
\text { BUDGET (US \$) } \\
\text { AFGHANISTAN }
\end{array} & 1987 \\
\text { PAKISTAN } & 3,310,1 \\
\text { TOTAL } & 3,310,1 \\
\hline 84
\end{array}
$$$$
\text { AFGHANISTAN }
$$$$
\text { TOTAL }
$$$$
3,310,185
$$

1988
1989

705,190

$3,285,994$

$3,991,184$
1990

$1,075,268$

$3,312,203$

$3,312,203$

$5,259,466$ 
The NORWEGIAN REFUGEE COUNCIL (NRC) and NORWEGIAN CHURCH AID (NCA) are voluntary, humanitarian organizations involved in relief and development programs throughout the world.

NCA is presently providing assistance to programs in more than 60 countries. Project activities range from emergency relief (distribution of food, tents, clothes and medicines) to involvment in long-term community development programs.

NRC originates from the Norwegian Aid to Europe, established in 1946 after World War II to assist distressed people in Europe. In 1952, the organizations which constituted Norwegian Aid to Europe, along with the Government, formed the Norwegian Refugee Council.

The first assistance given by NRC/NCA to Afghan refugees was in 1979/80. As funds from the Norwegian Government increased, it was decided to establish a joint NRC/NCA office in Peshawar in 1983. The purpose of the office was to keep a close working relationship with the partners receiving Norwegian funds as well as providing accurate reporting to the Norwegian Government on programs and the refugee situation. NRC/NCA has also implemented emergency relief programs among unregistered and newly arrived refugees. Implementing partners are currently: Austrian Relief Committee, Inter Church Aid, International Rescue Committee, CHREP and INDOORS. Assistance is,however, also given to other organizations and projects based on request and availability of funds.

In 1989 , the NRC/NCA Project Office was established. The following programs are implemented by this office:

1.Assistance to Skilled Afghan Refugees (ASAR).
ASAR is a UNHCR funded income generating project that identifies and gives material assistance to skilled refugees throughout NWFP.

2.Employment Exchange Department (EED) is trying to facilitate suitable jobs for educated Afghan refugees in order to prevent an Afghan braindrain from the area.

3.Technical Training Center, Peshawar (TTCP) is a UNHCR funded vocational school for Afghan refugees. The TTCP is also having a program for handicapped refugees.

4.Norwegian Assistance to Skilled Afghans (NASA) is identical with the ASAR project, but is implemented in Afganistan.

5. Rehabilitation Program for Afghanistan is planning the following projects in Afghanistan:

- Technical Training Centre

- Training Centre for Poultry Farming.

- Production of concrete elements.

Funding: Norwegian Government, UNHCR, World Bank and private donations. 


\section{LOCAL ADDRESS}

38D-2 OLD JAMRUD ROAD

UNIV TOWN PESHAWAR, PAK

38D-2 OLD JAMRUD ROAD

UNIV TOWN PESHAWAR, PAK

TEL: 40410

TXL: 52393 UNHCR PK

FAX:

MR. MICHAEL STONE (DIRECTOR)

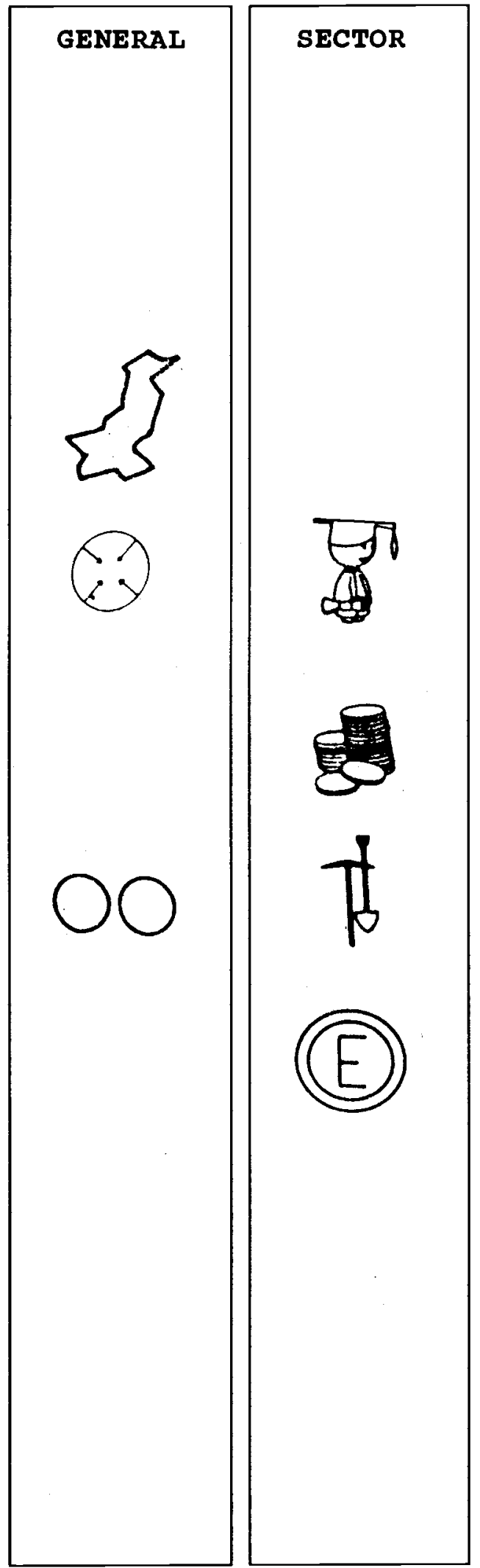

\section{HEADQUARTERS}

MR. LOBSANG YESHI

GUILDFORD ROAD

WOKING SURREY, ENGLAND

TEL:

TXL: 859213

FAX:

\begin{tabular}{|lrr|}
\hline \multicolumn{3}{|c|}{ PERSONNEL } \\
EXPATS & 1 & $2 \%$ \\
AFGHANS & 68 & $90 \%$ \\
PAKISTANIS & 6 & $8 \%$ \\
TOTAL & 75 & \\
\hline
\end{tabular}

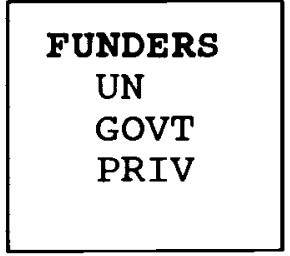

1988

1989

1990

BUDGET (US \$) 1987

AFGHANISTAN

PAKISTAN

$1,736,111$

TOTAL

$1,736,111$

$1,331,853$

$1,224,289$

467,508

$1,331,853$ 
Founded in England in 1947, specifically to assist refugees of war-torn Europe, THE OCKENDEN VENTURE (OV) has extensive operations within U.K., in Sudan, Thailand, India, Macau, and interests in Tibet, Vietnam and Ethiopia. Ockenden Pakistan was established in 1984 , and is the largest of the overseas operations. OV takes interest in all aspects of refugee assistance, including their emergency emigration, health, education and welfare.

Pakistan programs for Afghan refugees are divided into four areas of assistance:

1. Handicrafts. The largest producer of Afghan handicrafts in Pakistan. Over 2700 of the poorest Afghan refugees are employed, producing over 450 different handicraft items, including: jewellery, embroidered items, knitted socks and gloves, leather bags, toys, art work, carpets, clothes, and "Bedford trucks." Additionally, O.V. markets the products of eight other agencies. Seventy percent of the production is now exported.

2. Construction. Ockenden constructs and maintains schools, warehouses, BHUs, roads, and bridges. Locations of such projects include: Swat, Dir, Malakand, Chitral and Kohat. Ockenden employs possibly 2000 refugee men on construction projects. OV is also constructing for various UN agencies, e.g. making wooden pallets, site preparation and tent erection for UNILOG in Saifan Abad.

3. Quilt Making. Ockenden is the largest maker of handmade quilts in Pakistan. Its main production facilities are located in Kababian, Michni and Khazana Camps - from which other camps are also serviced. Over 1400 Afghan refugees, of which 1100 are women, are employed by Ockenden when the facility is operating at full capacity of 2000 quilts daily, or 400,000 per annum.

4. Tailoring/School Uniforms. Ockenden is the largest Afghan refugee producer of school uniforms in Pakistan. In 1989, it is expected that 42,000 uniforms will be produced, in different sizes, together with 42,000 canvas school bags and 23,600 school caps. Ockenden employs 400 tailors on this project.

5. Other Areas. Ockenden has constructed and now operates a school for Afghan refugee children in Kababian Camp and has constructed a Carpet Training Center in Akura Khattak Camp.

Funding: $\quad$ ODA and UNHCR. 


\section{LOCAL ADDRESS}

HOUSE 12, STREET 42 F8/1 ISLAMABAD, PAK HOUSE 12, STREET 42 F8/1 ISLAMABAD, PAK

TEL: (051) 851026

TXL:

FAX:

MR. MICHAEL SEMPLE

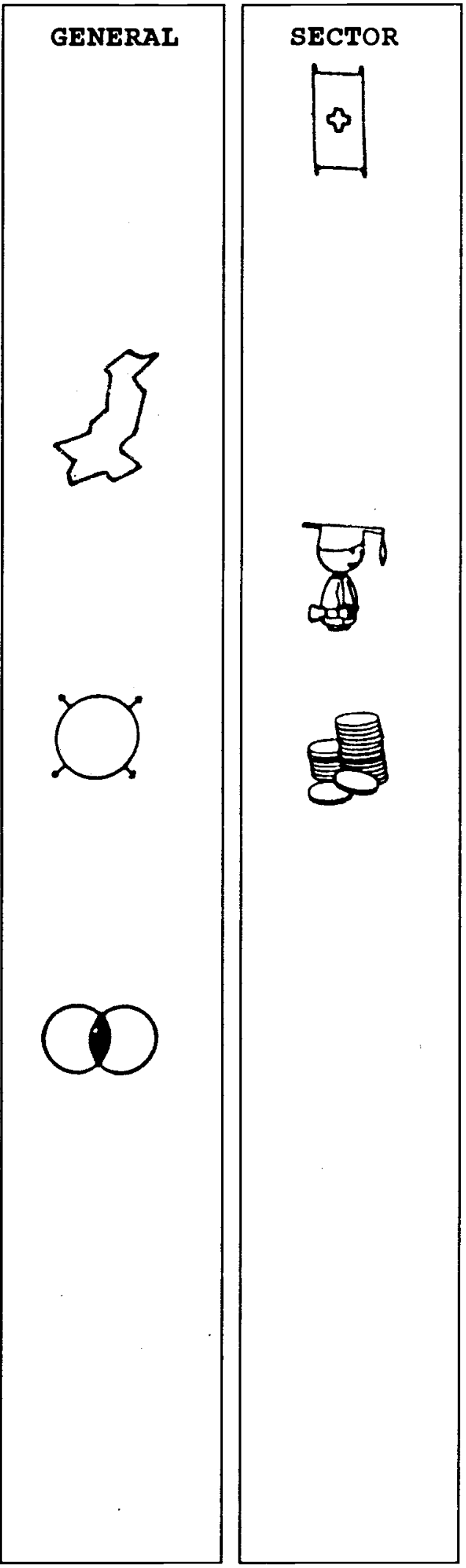

\section{HEADQUARTERS}

MS . ALISON BARRETT

OXFAM HSE, 274 BANBURY RD

OXFORD OX2 70Z, UK

TEL: 56777

TXL: 83610

FAX: 086557612

\begin{tabular}{|lrr|}
\hline \multicolumn{3}{|c|}{ PERSONNEL } \\
EXPATS & 1 & $14 \%$ \\
AFGHANS & 0 & $0 \%$ \\
PAKISTANIS & 6 & $85 \%$ \\
TOTAL & 7 & \\
\hline
\end{tabular}

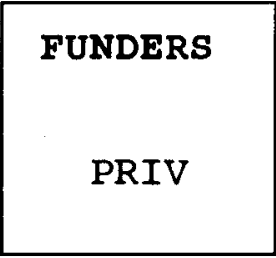

BUDGET (US \$) 1987

AFGHANISTAN

PAKISTAN

TOTAL
1989

51,909

51,909

\section{0}

46,759

66,389

113,136 
OXFAM is a British humanitarian organization assisting relief and development in 74 countries. About $93 \%$ of its funds are generated from private donations and other non-government sources in the United Kingdom.

OXFAM primarily works through providing funds and other assistance to local non-governmental partners.

In $1988 / 1989$ OXFAM made 30 grants to organizations implementing programs for Afghan refugees, engaged in reconstruction activities inside Afghanistan.

In addition to its role as a donor, OXFAM is implementing a primary education project for Afghan refugees in Baluchistan.

Funding: private donations and grants from non-governmental organizations. 


\section{LOCAL ADDRESS}

G $P$ O BOX 641

POST CODE 25000 PESHAWAR, PAK

JAMAL ROAD STREET NO 5

TEL: 42987

SHAHEEN TOWN PESHAWAR, PAK

TXL:

FAX:

DR. M. A. DADFAR
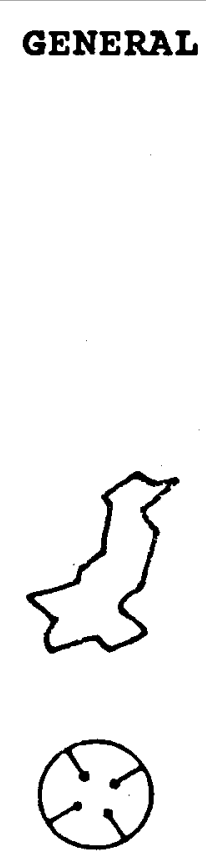

$\bigcirc \bigcirc$

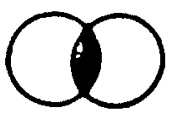

FUNDERS

UN

PRIV
SECTOR

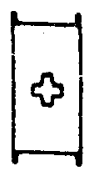

\section{EXPATS}

\section{PERSONNEL}

AFGHANS $25100 \%$

PAKISTANIS $00 \%$

TOTAL

25

$$
\begin{aligned}
& \text { BU } \\
& \text { AF } \\
& \text { PA } \\
& \text { TO } \\
& 90
\end{aligned}
$$


The PSYCHIATRY CENTRE FOR AFGHANS (PCA) was established in June 1986, with the official permission of Pakistan authorities responsible for Afghan refugees. The staff includes seven doctors, three nurses, six social workers, one physiotherapist, one pharmacist, and seven non-medical colleagues.

The main goal of the Centre is to provide psychiatric care to the Afghan refugees in Pakistan and to provide information on their psychological problems. The Centre sees approximately 100 out-patients per day. Because of the small size of the Centre and the large number of Afghan refugees, the physicians can provide only limited medical care and psychotherapy.

The Centre includes a special section for the treatment of torture victims and their families. This section received 590 Victims of Torture for treatment and psychiatric consultation between January 1986 and August 1989.

Since March 1989, the Centre has operated a mobile Psychiatric Unit.

Funding: Amnesty International, the United Nations Voluntary Fund for Victims of Torture, HELP (West Germany), and Norwegian Refugee Council 
$U$ P O BOX 922

UNIV TOWN PESHAWAR, PAK

HOUSE T-1914 BEHIND

BANGASH MOTORS UNIV RD PESHAWAR, PAK TEL: $42230 / 43912$

TXL:

FAX :

CAPTAIN IVOR S. TELFER

\section{LOCAL ADDRESS}

SUBOFFICE 1

VOCATIONAL TRAINING \& INCOME GENE. H. T-1914, BEHIND BANGASH MOTORS JAMRUD ROAD, PESHAWAR, PAK

TEL : 40910

MR. GHULAM JELANI (PROG. OFFICER)

\section{SUBOFFICE2}

HARIPUR MEDICAL PROJECT, FIELD OFF H. 133, SECTOR 2, KALABAT TOWNSHIP HARIPUR, PAK

TEL : 0595-9200

DR. ABDUL WAHAB (PROG. OFFICER)

DR. ZAIN-UL-ABEDIN (PROG. OFFICER) GHAZ I

\section{HEADQUARTERS}

COMM DUDLEY COLES

$\mathrm{P} O \mathrm{BOX} 249$

COL. JOHN NELOEN

P.O.BOX 242

LONDON EC $4 \mathrm{P}$ ENGLAND LAHORE 5000, PAK TEL: $01-2365222$

TXL: 8954847

FAX:

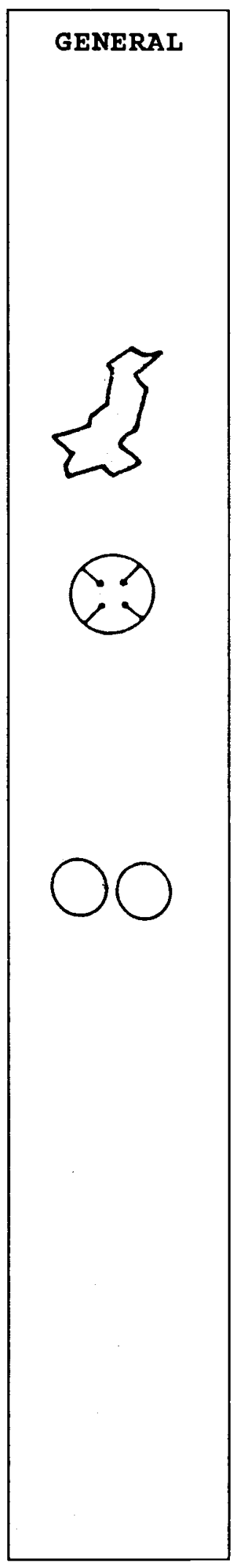

1989

1990

BUDGET (US

PAKISTAN

TOTAL

$1,065,052$

$1,168,080$

$1,123,090$

$1,500,000$

$1,065,052$

$1,168,080$

$1,123,090$

$1,500,000$
SECTOR
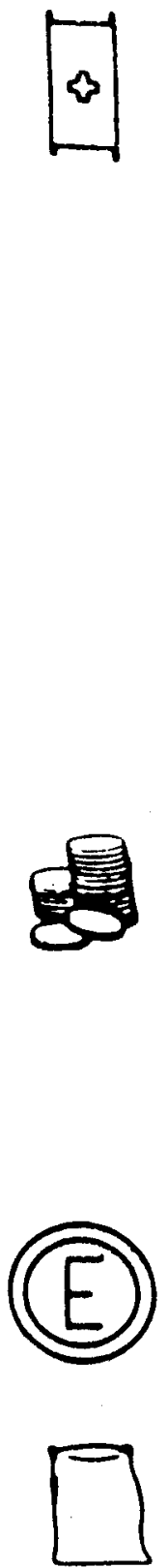
The SALVATION ARMY (SA) was founded in 1865 in England, as a nondenominational religious organization with a concern for social care. At present, it is working in 91 countries, providing millions of people with medical care, relief, shelter and education--regardless of race, religion or cultural background. The Salvation Army has been working in Pakistan, mainly in the Punjab, since 1947 , and in the Indian Sub-Continent since 1888.

It came to the Northwest Frontier Province in 1982, at the request of the Government of Pakistan to provide relief assistance to refugees migrating and settling in various parts of the Province. Activities commenced with the opening of two Basic Health Units at the Ghazi Camps near Tarbela and initially was also involved in some relief distribution of food and other essential items among the newly-arriving refugees.

At present, the Salvation Army runs six Basic Health Units: two in Ghazi and four in Haripur Camps. Specific areas of work apart from the Basic Health Units and the Community Health Education program are in vocational training, in which trainees are taught carpentry, welding, vehicle and tractor repair, and car body building. Income generation work includes embroidery, carpet and gillam weaving, soap making, a tannery project, leatherwork production and quilt making. An important step in this project is the handicraft catalogue, recently produced which features various items, ranging from Kandahari embroidered shawls to leather/gillam combination bags.

At present these leather items and leather/gillam combinations are being marketed in the Netherlands, Australia, the U.K., and an entry to the US market is being attempted. The marketing of handicrafts abroad is a vital area in which to become involved due to the lack of demand for these particular items in Afghanistan during any reconstruction.

Since the Salvation Army mandate will not allow the organization to work within a country unless it is able to work with a recognized government, at present the Project cannot move into Afghanistan. However, due to the small number of expatriates on the staff, the Project is in the position of being mainly administered/operated by Afghans. It is hoped that in the future, the Project will turn over the various programs to an Afghan non-governmental organization which would then be able to continue their implementation and secure funding independently of Salvation Army sources.
Funding: US Bureau for Refugee Programs, UNHCR, the Canadian International Development Agency, Help Age, Stichting Vluchteling and the Canadian Ambassador's Discretionary Fund. 

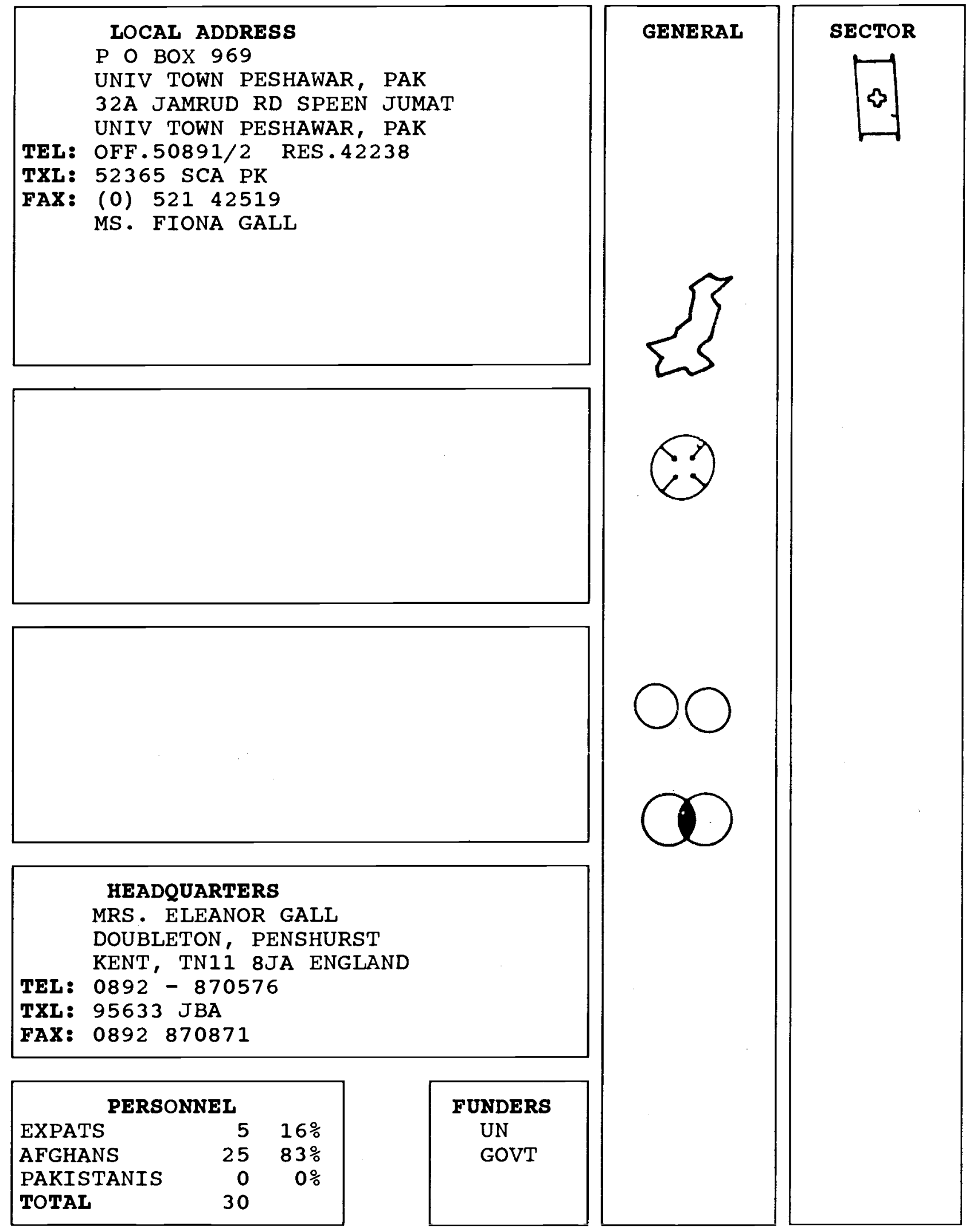

\section{HEADQUARTERS}

MRS . ELEANOR GALL

DOUBLETON, PENSHURST

KENT, TN11 8JA ENGLAND

TEL: 0892 - 870576

TXL: $95633 \mathrm{JBA}$

FAX: $0892 \quad 870871$

\begin{tabular}{|lrr|}
\hline \multicolumn{3}{|c|}{ PERSONNEL } \\
EXPATS & 5 & $16 \%$ \\
AFGHANS & 25 & $83 \%$ \\
PAKISTANIS & 0 & $0 \%$ \\
TOTAL & 30 & \\
\hline
\end{tabular}

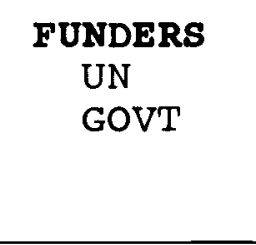

\begin{tabular}{|lcccc|}
\hline BUDGET (US \$) & 1987 & 1988 & 1989 & 1990 \\
AFGHANISTAN & & & & \\
PAKISTAN & 115,740 & 138,734 & 134,671 & 332,865 \\
TOTAL & 115,740 & 138,734 & 134,671 & 332,865 \\
\hline
\end{tabular}


SANDY GALL'S AFGHANISTAN APPEAL (SGAA) is a British NGO, organized to supply orthopaedic appliances for disabled Afghans and to train technicians to cast and fit prostheses and orthoses. The first project began in June, 1986, based in Lady Reading Government Hospital, Peshawar. Eighty percent of the patients were Afghan. A second project was started in April - in conjunction with Pakistan Red Crescent at their Rehabilitation Center in Peshawar in 1988, when two physiotherapists joined SGAA to work with disabled Afghan children. Currently, there are two projects: an orthopaedic workshop in Hayatabad, and a physiotherapy project in University Town.

The Physiotherapy Project is operated by the Pakistan Red Crescent and funded by UNHCR. SGAA supplies the expatriate physiotherapists. The clinic treats children with mobility disabilities, mostly polio victims, cerebral palsy and orthopaedic conditions. Children stay in the Centre for up to 15 days, if they live outside Peshawar, along with their parents; they are referred for callipers or for other walking aids. The parents are also shown and taught the exercises that must be continued at home. Follow-up and reassessment continues as is necessary. In addition to the Center, BHU's - sponsored through the Austrian Relief Committee receive the services of two technicians who identify and treat disabled children in two camps near Mardan.

In April 1989 new physiotherapy students were recruited. Eight students from different camps are being trained every four months at the PRC Center in Peshawar as CBR Workers (CommunityBased Rehabilitation Workers). After four months, they are sent back to the camps in pairs and open clinics in conjunction with the BHU's. This system should result in 12 Community-Based Physiotherapy
Centers with two CBR workers in different camps with back-up referral to PRCs Rehabilitation Center.

A newly-built unit in Hayatabad contains an orthopaedic workshop and a physiotherapy unit. The project at Hayatabad will provide increased production of prostheses and orthoses and will give a one-year training course in these areas. The physiotherapy unit will employ three technicians and six trainees who will work in conjunction with the workshop and two French medical NGO's, providing orthopaedic rehabilitation physiotherapy and post-surgical physiotherapy, both in-patient and outpatient.

Funding: $\quad$ UNHCR and WHO. 
LOCAL ADDRESS

P O BOX 1952

ISLAMABAD PAK

68 NAZIMUDDIN ROAD

F8/4 ISLAMABAD PAK

TEL: (051) 854690,853651,856727

TXL: 54074 TECMA PK

FAX:

MR. SULTAN AZIZ (FIELD OFFICE DIR)

MR. GARY MAHR

ASKARI JAFERI

\section{SUBOFFICE 1}

P.O. BOX 1050

UNIV. TOWN

PESHAWAR, PAK

TEL: (0521) 43249/42462

MS. JAN GOODWIN (REPRESENTATIVE)

MR. MARK WILLIAMS

\section{SUBOFFICE2}

QUETTA PGM OFFICE

30-A CHAMAN HSG

QUETTA, PAK

TEL: 081 OFF.77005/CRAFT. 22397

MR. PAUL FISHSTEIN (PROG. MANAGER)

MR. AZIM AKHTAR

\section{HEADQUARTERS}

MR. JIM SOULES (REGIONAL DIRECTOR) 54 WILTON ROAD

WESTPORT, CT 48861 USA

TEL: $203 \quad 2267271$

TXL: 6717734 MENA

FAX:

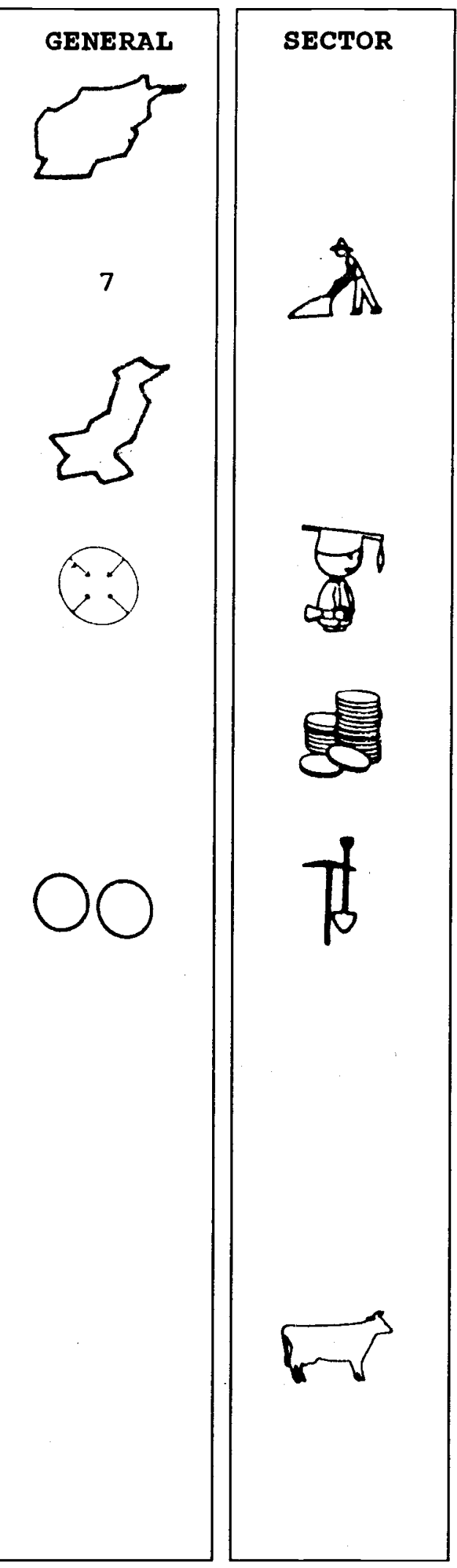

FUNDERS

UN

GOVT

PRIV
BUDGET (US \$)

AFGHANISTAN

PAKISTAN

TOTAL

\section{7}

11,574

810,185

821,759
1988

110,987

943,396

$1,054,383$

\section{9}

$1,224,289$

$1,126,346$

$2,350,635$
1990

$1,718,092$

$1,718,092$

$3,436,184$ 
SAVE THE CHILDREN FEDERATION - USA (SCF-US) was founded in 1932, operates community development programs in 39 countries, aimed at improving the well-being of children and their families. In July 1985, SCF began its first projects for Afghan refugees in Pakistan.

In Pakistan SCF-US operates self-help projects for Afghan refugees in Mianwali, Mansehra, Quetta and Islamabad which offer training in basic literacy and numeracy, construction, skills training (Weaving, tailoring, carpet making, carpentry) and craft production. Literacy programs are also incorporated into all SCF skills training projects.

Save the Children Federation currently runs projects in seven provinces in Afghanistan: Zabul, Ghazni, Kandahar, Nangarhar, Balkh, Wardak and Baghlan. SCF assists communities in Agricultural rehabilitation by providing seed, fertilizer, plant protection, veterinary services, repairing irrigation systems and other practical agricultural assistance. The SCF Rural Works programs inside Afghanistan focus on reconstructing damaged infrastructure such as schools, roads and clinics. SCF has initiated craft production projects in five provinces. In addition to badly-needed supplemental income, it is expected that these projects will be a precursor to health programs for women and children.

The Federation works toward "Afghanization;" at all levels of implementation, it promotes community involvement. The essence of SCF philosophy is that everyone, no matter how economically or socially deprived has the capacity to take charge of their lives. In Afghanistan as well as in Pakistan, SCF is committed to helping Afghan communities help themselves. Assistance is provided Afghans, whether living in
Pakistan as refugees, in transit to their native villages, or rebuilding their homes. The long-standing commitment of SCF to helping restore self-sufficiency to victims of political upheaval and natural disaster is demonstrated in its programs for Afghans through the Pakistan Field Office.
Funding: UN agencies, governmental and nongovernmental funding bodies, and private and corporate donations. 
LOCAL ADDRESS

39D $S \mathrm{~J}$ AFGHANI ROAD

UNIV TOWN PESHAWAR, PAK

39D $S$ J AFGHANI ROAD

UNIV TOWN PESHAWAR, PAK

TEL: $41170 / 41918$

TXL: 52369 PCOPE PK

FAX :

MR. MATTHEW BULLARD

GENERAL

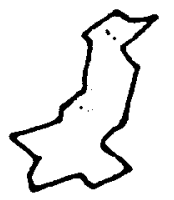

68

$\bigcirc \bigcirc$

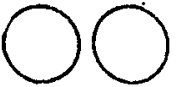

\section{HEADQUARTERS}

DR. BOB PARSONS

MARY DATCHELOR HOUSE

17 GROVE LANE LONDON SE5 UK

TEL: LONDON 7035400

TXL: 892809 SCF LONG

FAX:

\begin{tabular}{|lrr|}
\hline \multicolumn{3}{|c|}{ PERSONNEL } \\
EXPATS & 5 & $2 \%$ \\
AFGHANS & 100 & $57 \%$ \\
PAKISTANIS & 70 & $40 \%$ \\
TOTAL & 175 & \\
\hline
\end{tabular}

FUNDERS

UN GOVT

PRIV

BILAT
BUDGET (US \$) 1987

AFGHANISTAN

PAKISTAN

TOTAL
1988

1989

1990

$779,351 \quad 1,285,517$

$779,351 \quad 1,285,517$ 
SAVE THE CHILDREN FUND - UK (SCF-UK) is Britain's largest international children's charity. Founded in 1919, it is an independent voluntary organization, professionally staffed. SCF is wholy concerned with rescue in disaster and the longer term welfare of children in hunger, sickness and need. The Fund is entirely nonpolitical and at the present time is working in over fifty countries.

Great importance is attached to training local workers in the developing world in the professional and technical skills essential to the advancement of child welfare in the fullest sense. It is part of the Fund's philosophy that it should work, wherever possible, with governments or UN agencies. Prior to 1979, SCF had been working in Afghanistan for many years. When the war broke out it was one of the first organizations to move to Peshawar and set up two clinics at Badaber refugee camp. SCF has been serving the refugee population in Badaber through its two Basic Health Units since 1980.

In 1983, after considering the health of the refugees throughout the Northwest Frontier it was decided that a system of Primary Health Care should be instituted in order to provide a more comprehensive health care program. The Fund's PHC program consists of both male and female training components.

The aim of the male PHC program is to train candidates from amongst the refugee community as teachers of primary health care. These teachers are called Community Health Supervisors (CHS's). The training is done by SCF's own Afghan staff at a large residential training centre near Peshawar. Once qualified, the CHS's - who are paid a small salary - in turn train up to 30 volunteer Community Health Workers (CHW's) within their own family groupings. The CHW's are taught about the prevention of disease and basic medical interventions. By 1989 the male program had reached seven districts and agencies in NWFP and had trained over 160 CHSs and 3150 CHW's.

The concept of the female program is similar to that of the male except it focuses on safe delivery techniques and mother and child health. Through the support of the Government of Pakistan's Project Director Health, SCF employs 14 Pakistani Lady Health Visitors, whom SCF has trained to educate traditional birth attendants, the local village midwives, either as Female Health Supervisors (FHS's) or Female Health Workers (FHW's).

Both the male and female programs train supervisors and workers for other agencies. By mid-1989, SCF-trained Afghans were covering a population of well over one million refugees.
Funding: UN-agencies. 
LOCAL ADDRESS

$P$ O BOX 477

UNIV TOWN PESHAWAR, PAK

5 MULBERRY ROAD

UNIV TOWN PESHAWAR, PAK

TEL: $41706 / 43253$

TXL: 52369 PCO PE PK ATTN SERV

FAX: $521-42422$

MR. GORDON MAGNEY

MR. STEVE CRAIG

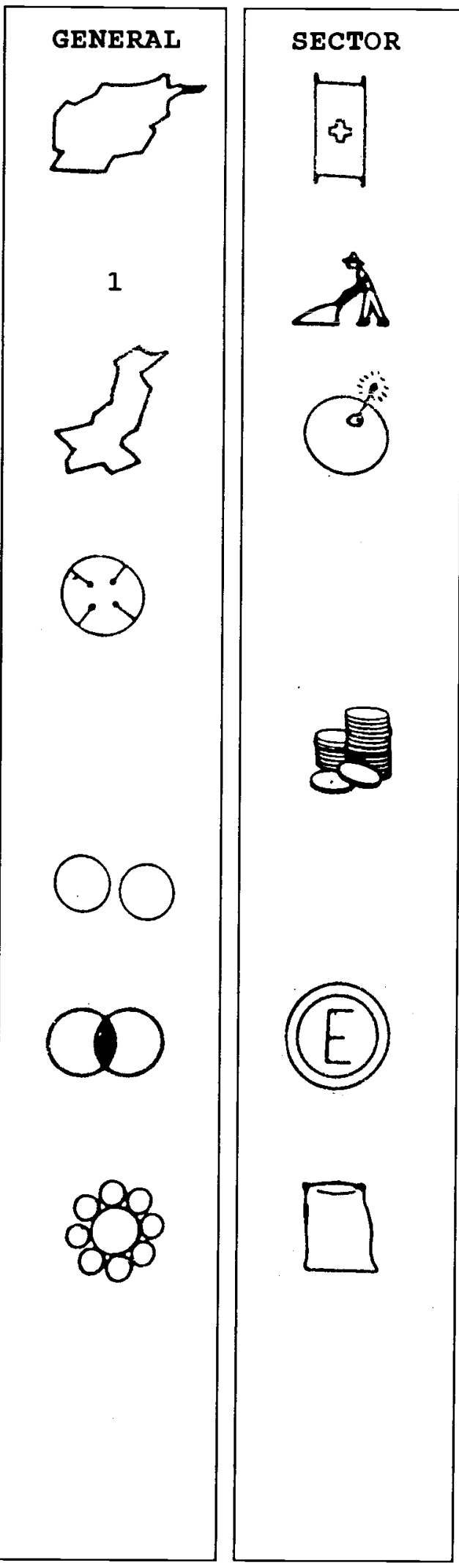

HEADQUARTERS

DR. HOWARD HARPER

3A CAMDEN PARK

TUNBRIDGE WELLS KENT TN2 4TW, ENGLAND TEL:

TXL:

FAX:

PERSONNEL

$\begin{array}{lrr}\text { EXPATS } & 25 & 20 \% \\ \text { AFGHANS } & 100 & 78 \% \\ \text { PAKISTANIS } & 4 & 2 \% \\ \text { TOTAL } & 129 & \end{array}$

FUNDERS

UN

GOVT

PRIV
SECTOR

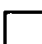$$
\text { BUDGET (US \$) }
$$$$
\text { AFGHANISTAN }
$$$$
\text { PAKISTAN }
$$$$
\text { TOTAL }
$$

1987
728,221
720,221

\section{8}

813,096

813,096

\section{9}

106,465

$1,146,252$

$1,252,717$
1990

154,277

$1,215,521$

$1,349,798$ 
SERVING EMERGENCY RELIEF AND VOCATIONAL ENTERPRISES (SERVE) started operations in 1980 with two projects: relief aid to newly-arriving refugees and public health. Carpet weaving training started in 1981. During the past nine years SERVE has expanded its work to include the production and distribution of solar ovens, a reforestation program, an eye hospital and orientation and mobility training for blind Afghan refugees.

SERVE has three major goals: to continue providing emergency relief help as long as Afghans are arriving in Pakistan in need of immediate assistance; to meet the ongoing needs of the majority of refugees who are dependent on NGO assistance; and to provide vocational, incomegenerating skills.

1. Emergency relief help. The Relief Project is currently providing the monthly rations to 1,550 newlyarrived families in Shin Dhand Camp as well as dealing with specific needs of smaller groups that are brought to the attention of SERVE by individual Afghans, CAR and other NGOs.

2. On-going needs. The Afghan Eye Hospital (AEH) sees an average of 1,850 patients and performs an average of 100 operations monthly. In 1988 AEH started an artificial eye workshop, the only one in NWFP. Since 1980 the Public Health Project has produced a set of 16 health and hygiene charts in Pushtu and Dari, 13 health and hygiene books in Pushtu and is currently producing these in Dari. The books are used in Afghan schools, and specific health teaching is given to teachers, students and women in camps in the NWFP, as well as utilized by
NGOs in Pakistan and Afghanistan. A vaccination program for women and children in Kheshki Camp started in September 1989. The Solar Oven Project is currently developing a light-weight, "flute board" oven suitable for carrying back to Afghanistan. Sheetmetal ovens are manufactured by Afghans in the Solar Oven Workshop.

3. Income generating skills to the Afghans. The Carpet Weaving Centre has trained 133 Afghan boys in carpet weaving. No longer giving training, the Centre provides a marketing service for these boys and other Afghan carpet weavers. The Forestry Project has helped Afghan nurserymen establish 141 fast-growing tree nurseries in the NWFP and seven in Afghanistan. The nurserymen sell their tree seedlings to their neighbors. As of September 1989, The Orientation and Mobility program had provided freedom of movement to 89 blind persons. Twenty percent of these trainees are now earning an income through their own businesses. Where feasible, crossborder work has been established.

Funding: $\quad$ TEAR Fund and Christoffel Blindenmission, UNHCR and private donations. 

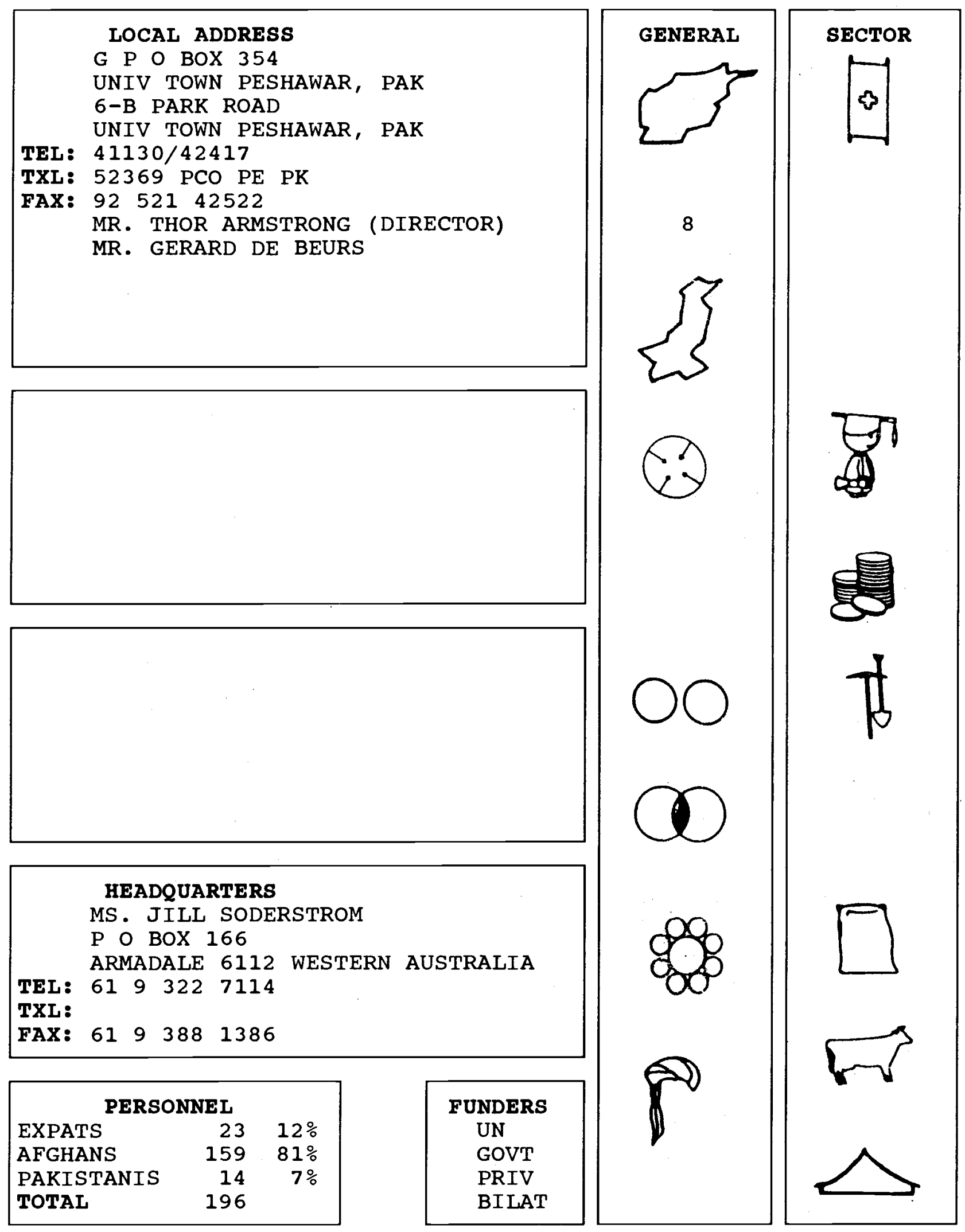

\section{HEADQUARTERS}

MS. JILL SODERSTROM

$P$ O BOX 166

ARMADALE 6112 WESTERN AUSTRALIA

TEL: $61 \quad 9 \quad 322 \quad 7114$

TXL:

FAX: $61 \quad 9 \quad 388 \quad 1386$

\begin{tabular}{|lrr|}
\hline \multicolumn{3}{|c|}{ PERSONNEL } \\
EXPATS & 23 & $12 \%$ \\
AFGHANS & 159 & $81 \%$ \\
PAKISTANIS & 14 & $7 \%$ \\
TOTAL & 196 & \\
\hline
\end{tabular}

\begin{tabular}{|l|} 
FUNDERS \\
UN \\
GOVT \\
PRIV \\
BILAT \\
\hline
\end{tabular}

\begin{tabular}{|lcccr|}
\hline BUDGET (US \$) & 1987 & 1988 & 1989 & 1990 \\
AFGHANISTAN & & & 414,268 & 818,139 \\
PAKISTAN & $1,646,013$ & $2,208,825$ & $1,021,390$ & 864,890 \\
TOTAL & $1,646,013$ & $2,208,825$ & $1,435,658$ & $1,683,029$ \\
\hline
\end{tabular}


SHELTER NOW INTERNATIONAL (SNI) was established in 1979 , as an international volunteer relief organization, the aim of which was to provide shelter and other forms of humanitarian aid to those in need. SNI is registered in Australia and the US as a non-profit charitable organization.

Since 1982, SNI has been involved in providing assistance to the Afghan Refugees in Pakistan. Projects include establishing a pre-cast concrete factory run by Afghans, a housing project for widows, orphans, and the disabled. income generation through various construction projects, a large milk distribution program, a basic health and literacy program, a counseling service for widows, and a poultry project.

In 1989 SNI began implementing projects inside Afghanistan. Current projects include constructing and upgrading $40 \mathrm{~km}$ of road in Kandahar province - a joint project with Mercy Corps International, repair of twenty-two km of road in Kunar Province, and the construction of a precast concrete roofing factory in the Shinwar district of Nangahar Province. SNI is also undertaking a vaccination program in collaboration with COMDEV International for karakul sheep in Balkh. Additionally, SNI manages construction projects for other NGOs both in Pakistan and Afghanistan who are in need of engineering services but lack technical expertise. For example, SNI is presently constructing five clinics and two hospitals in Afghanistan for International Medical Corps.

An example of an SNI Project is the precast Concrete Factory which was established in 1983 at Nasir Bagh and began producing modular geodesic domes to be used in the camps as administration buildings, storage facilities and clinics. This innovative dome is a low-cost, multi- purpose structure that is now being widely used in many refugee camps throughout NWFP and other parts of Pakistan. In addition to the domes, many other precast items are now produced by the factory including concrete beams and roof slabs, toilet slabs and well rings for sanitation projects, and steel framed doors and windows. The factory is managed by our Afghan staff and approximately 200 refugees have regular employment there.
Funding: private donations, Christoffel Blinden Mission, World Vision International, UNHCR, UNDP, WFP and the European Community. 
LOCAL ADDRESS

G P O BOX 326

POST CODE 25000 PESHAWAR, PAK

ITC ADMIN ENCLAVE PLOT A3

HAYATABAD PESHAWAR, PAK

TEL: OFF.50891/50892 RES.42319

TXL:

FAX:

MR. CHRISTIAN GRAVET
GENERAL

SECTOR

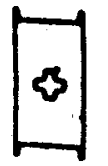

HEADQUARTERS

MR. ANDRE COLLARD

110 RUE DES VENNES

4020 LIEGE BELGIUM

TEL: 0032.41 .414056

TXL:

FAX:

\begin{tabular}{|lrr|}
\hline \multicolumn{3}{|c|}{ PERSONNEL } \\
EXPATS & 10 & $35 \%$ \\
AFGHANS & 15 & $53 \%$ \\
PAKISTANIS & 3 & $10 \%$ \\
TOTAL & 28 & \\
\hline
\end{tabular}

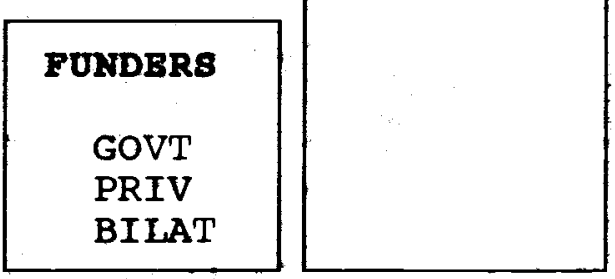

\begin{tabular}{|lcccc|}
\hline BUDGET (US \$) & 1987 & 1988 & 1989 & 1990 \\
AFGHANISTAN & & & & \\
PAKISTAN & 231,481 & 277,469 & 244,857 & 280,504 \\
TOTAL & 231,481 & 277,469 & 244,857 & 280,504 \\
\hline
\end{tabular}


SOLIDARITE AFGHANISTAN BELGIUM / MEDICAL TRAINING FOR AFGHANS (MTA) is a Belgian non-governmental organization working in close collaboration with SOS PG Belgium, another Belgian NGO and with Aide Medicale Internationale (AMI), a French NGO. (For projects done cooperatively with SOS/PG Belgium, please see "SOS/ PG Belgium-Solidarite Afghanistan in this directory.) Solidarite Afghanistan Belgium, in collaboration with Aide Medicale Internationale, implements a medical training program for "assistant doctors," titled Medical Training for Afghans.

Participants in the MTA program are recruited inside Afghanistan through the assistance of political parties and/or commanders. The 16-month training course consists of both "theoretical courses" and actual medical experience with patients, provided through a "schoolhospital" of 25 beds at Hayatabad. All patient care is medical and pedagogic at the same time: every medical examination, procedure or treatment is made with a teacher-doctor, a translator and one or several students. An outpatient department attends patients both at the hospital and in camps. Students, upon graduation, are sent back into Afghanistan. There, the Assistant Doctors are able to run their own small clinics in their home villages. However, although trained to work alone in remote areas of Afghanistan, they also have the knowledge to run larger hospitals, and are thus able to meet various needs of the health structure to be established in Afghanistan.

Four classes of graduates are already working inside Afghanistan - a total of 53 Assistant Doctors; a fifth class of 18 students is now in training and will graduate in September 1990. Recruitment for a sixth class will take place in March 1990 , to begin training in May.
Materials or supplies and salaries of Assistant Doctors are paid for by the Swedish Committee and/or MSH. Monitoring "inside" is also provided by the Swedish Committee and MSH, along with CMC missions and by Aide Medicale Internationale.
Funding: Belgian and French Governments, the European Community, IRC and private Belgian donors. 
LOCAL ADDRESS

WHITE HOUSE 2 PARK LANE

UNIV TOWN PESHAWAR, PAK

WHITE HOUSE 2 PARK LANE

UNIV TOWN PESHAWAR, PAK

TEL: 42320

TXL : 52490 WHOUS PK

FAX: 42461

MR. PATRICK BRIZAY (DIRECTOR)

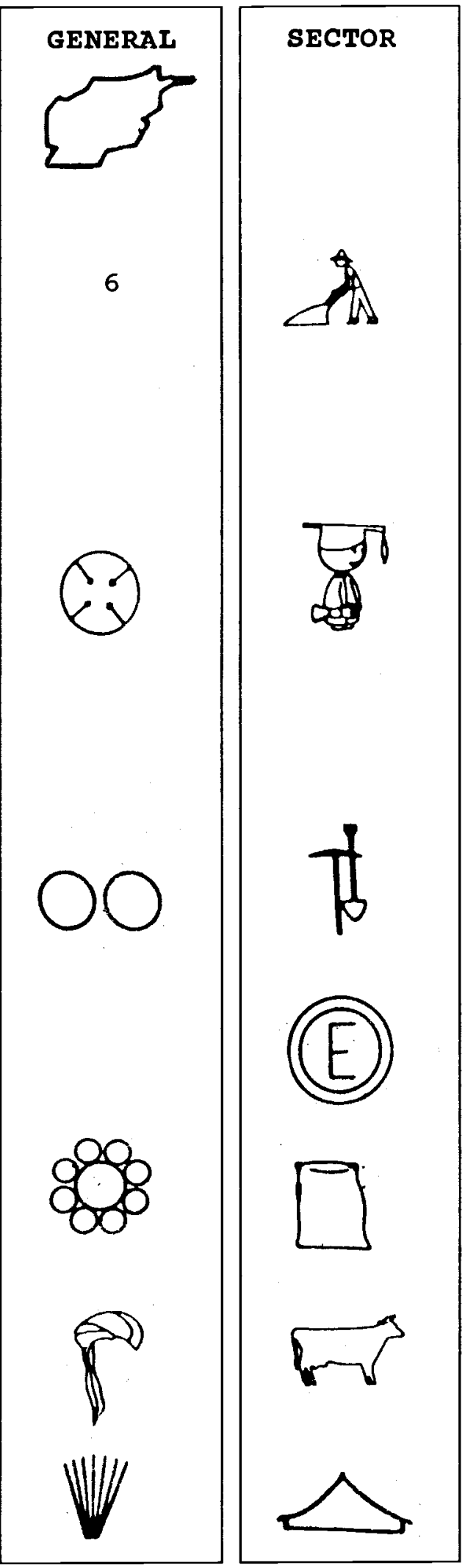

HEADQUARTERS

MR. ALAIN BOINET

19 RUE DAVIEL

75013 PARIS FRANCE

TEL: $1 \quad 45 \quad 88 \quad 33 \quad 22$

TXL:

FAX:

\begin{tabular}{|lrr|}
\hline \multicolumn{3}{|c|}{ PERSONNEL } \\
EXPATS & 4 & $25 \%$ \\
AFGHANS & 4 & $25 \%$ \\
PAKISTANIS & 8 & $50 \%$ \\
TOTAL & 16 & \\
\hline
\end{tabular}

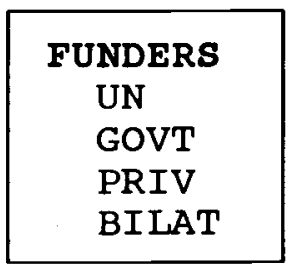

$\begin{array}{lc}\text { BUDGET (US \$) } & \mathbf{1 9 8 7} \\ \text { AFGHANISTAN } & 1,215,277\end{array}$

1988

PAKISTAN

289,351

TOTAL

$1,504,628$
$1,526,082$

305,216

$1,831,298$
1989

$1,526,082$

305,216

$1,831,298$
1990

467,508

140,252

607,760 
SOLIDARITE AFGHANISTAN / GUILDE DU RAID (SA/GR) is a humanitarian association, governed under a charter dating from 1901. From 1980 to 1987 , it acted under the auspices of the Guilde Europenne du Raid. The mandate of the organization provides for emergency relief to countries where populations are dispossessed due to war or natural disasters. Solidarite-Afghanistan also collects and disseminates information about the populations it otherwise serves. Emergency aid is given in the form of food, along with more long-range development programs in education and agriculture. Emphasis too is given to the re-establishment of physical and social infrastructures.

Humanitarian assistance in Afghanistan is offered in the following sectors:

1. Agriculture: technical support in irrigation projects. Such projects constituted $75 \%$ of the total budget in 1988. During 1989, 24 karezes and eight canals were constructed. Other agricultural projects: supply of implements, e.g., tractors, harvesters, distribution of seed and fertilizer, cereals bank, and management and administration of such support;

2. Education: building or otherwise providing educational facilities for between 300 and 1000 pupils according to province, provision of scholarship materials and salaries for teachers;

3. Emergency help: distribution of survival commodities in more than 1000 villages;

4. Infrastructures: assistance in rebuilding of physical (roads, bridges) and social infrastructures (communications systems).
Work is done in cooperation with the local commanders, through shuras and the political parties. Aid is always accomplished through on-site representation of the organization and under the local authority of the population representatives, through the local structures.

Funding: private donors, French and other European and American associations, the French Government, the European Community and UN agencies. 
LOCAL ADDRESS

P O BOX 799

UNIV TOWN PESHAWAR, PAK

ITC INDST ENCLAVE PLOT A3

HAYATABAD PESHAWAR, PAK

TEL: 50891

TXL:

FAX:

MR. BENOIT HEUCHENNE

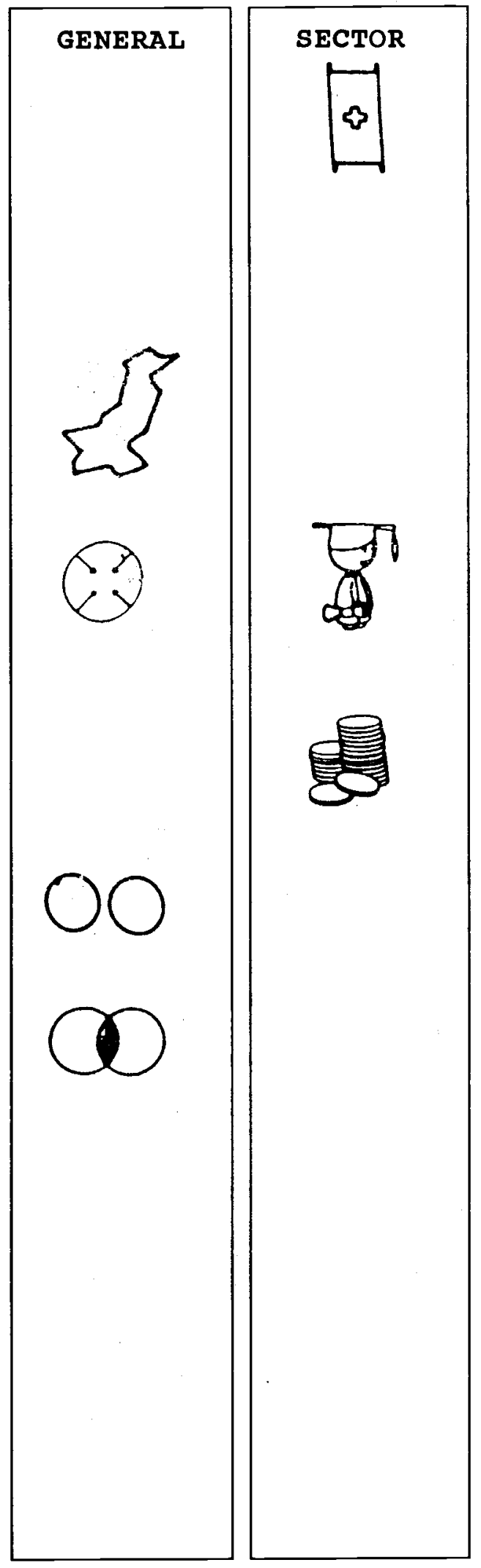

HEADQUARTERS

MR. ANDRE COLLARD

110 RUE DES VENNES

4020 LIEGE BELGIUM

TEL: 0032.41 .414056

TXL:

FAX:

\begin{tabular}{|lrr|}
\hline \multicolumn{3}{|c|}{ PERSONNEL } \\
EXPATS & 2 & $3 \%$ \\
AFGHANS & 59 & $86 \%$ \\
PAKISTANIS & 8 & $11 \%$ \\
TOTAL & 69 & \\
\hline
\end{tabular}

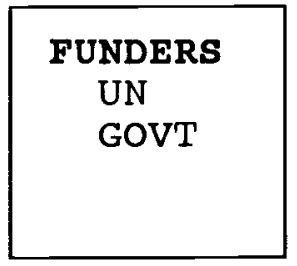

\begin{tabular}{|lcccc|}
\hline BUDGET (US \$) & 1987 & 1988 & 1989 & 1990 \\
AFGHANISTAN & & & & \\
PAKISTAN & 344,350 & 460,748 & 550,614 & 522,178 \\
TOTAL & $\mathbf{3 4 4 , 3 5 0}$ & $\mathbf{4 6 0 , 7 4 8}$ & 550,614 & 522,178 \\
\hline
\end{tabular}


SOS/PG BELGIUM was founded in 1980, a joint venture with Solidarite Afghanistan. The program was started in Peshawar in 1984, with its Teacher Training Program, to upgrade the teaching skills of primary teachers in the refugee camps of UNHCR and CAR.

In 1985, an Apprenticeship Scheme for Young Afghan Refugees was started in Peshawar and Mardan to provide professional training for young refugees. Now there are sub-offices in Mardan, Haripur, Manshera, Temergarah, Bajaur and Hangu. There is also a branch in Mianwalli, Punjab.

In 1988, a team of specialists--the Pedagogic Mobile Team--began daily visits in primary schools to assist teachers in their methodologic approaches.

NOTE: Additional and more detailed information can be found under: Solidarite Afghanistan.

Funding: UN HCR, B e l g i a n Government. 


\section{LOCAL ADDRESS}

$U$ P O BOX 689

POST CODE 25000 PESHAWAR, PAK

41 A CIRCULAR ROAD

UNIV TOWN PESHAWAR, PAK

TEL: (0521) 40415/42218/43279

TXL: 52365 SCA PK

FAX: (0521) 42519

MR. ANDERS FANGE (REPRESENTATIVE)

MR. BO ELDING (DEPARTMENT REPRE.)

MR. INGEMAR ANDERSSON (ADMINISTR.)

MS TURID RHODIN (FINANCE)

DR. REZA HAIDER (MED. PROJECT)

MR. DON SMITH (AG. PROJECT)

SUBOFFICE 1

AGRIC SURVEY AFGHANISTAN

U P O BOX 689 (ASA)

PESHAWAR, PAK

TEL：(0521) 42719/42769

DR. AZAM GUL (DIRECTOR)

MR. TIMOTHY CAMMAK (FINANCE/ADMIN)

SUBOFFICE2

AFGHANISTAN EDUC COMMITTE

$U P$ BOX 876 (AEC)

PESHAWAR, PAK

TEL：(0521) 41247

MR. BATINSHAH SAFI (DIRECTOR)

MR. STAFFAN FORSELL (PROJ . MANAG)

HANNEKE KOUWENBERG

\section{HEADQUARTERS}

MR. JAN STOLPE (CHAIRMAN)

ESSINGERINGEN 90

S-112 64 STOCKHOLM SWEDEN

TEL: $0046 \quad 8 \quad 133000$

TXL: 16598 SVAKOM (SWEDEN)

FAX: $0046 \quad 8 \quad 133800$

\begin{tabular}{|lrr|}
\hline \multicolumn{3}{|c|}{ PERSONNEL } \\
EXPATS & 15 & $4 \%$ \\
AFGHANS & 295 & $94 \%$ \\
PAKISTANIS & 3 & $0 \%$ \\
TOTAL & 313 & \\
\hline
\end{tabular}

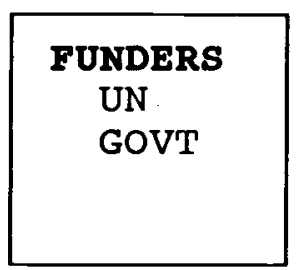

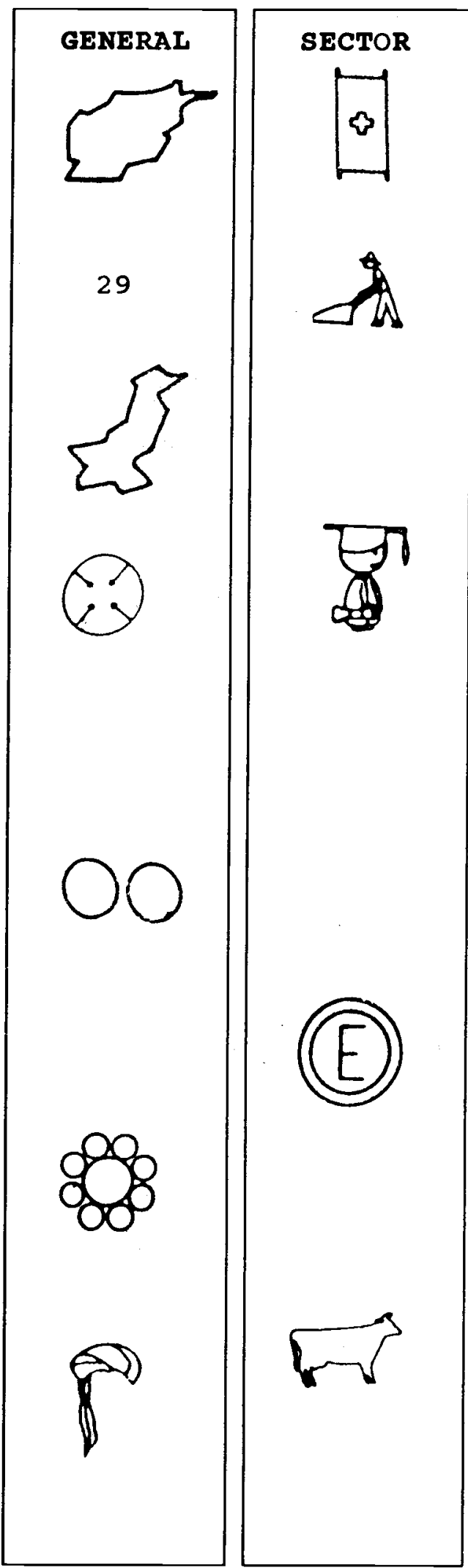

1988

1989

1990

$5,982,241 \quad 9,196,865 \quad 11,785,881$

$1,587,125$

$7,569,366$

$2,213,516$

$2,987,377$

$11,410,318 \quad 14,773,258$ 
The SWEDISH COMMITTEE FOR AFGHANISTAN (SCA) was founded in 1980 shortly after the Soviet invasion, "to contribute to the re-establishment of the national independence of Afghanistan," through information to the Swedish people about conditions in Afghanistan and through humanitarian aid in the liberated areas of Afghanistan.

The SCA Peshawar office was established in the autumn of 1982 . Work started in the health sector. Afghan medical personnel were supported with medical equipment, medicines, transport costs and salaries. In 1988, 222 tons of medicines were delivered to roughly 1,500 health workers in all the 29 provinces, including 85 health centers. Expansion continues in 1989 , while efforts are made to upgrade the quality of the health work and to encourage the development of larger, better-managed health systems, organized more towards preventive care.

Emergency relief was started on a small scale in 1984. A cash-for-food program was developed but funds have, over the last two years, been transferred to an agricultural program, which in 1989 supports 15 projects in Afghanistan; mainly involving seed, fertilizer, and irrigation. Training courses for plant protectionists, horticulturists and para-veterinarians are conducted. An emergency program still exists but with a slightly changed direction.

The Agricultural Survey of Afghanistan is a sub-branch of SCA. Started in fall 1986, its purpose was to conduct a nation-wide survey of the agricultural conditions in Afghanistan. The first report was distributed in May 1988; during 1989 a series of five more detailed reports, ranging from farm power to crops and yields has been or will be published. ASA also undertook a survey of suspected insect infestation in northern Afghanistan during the summer of 1989. The report was issued in September.

Work in the education sector started in 1984, when the sub-branch, Afghanistan Education Committee, was established. A primary school curriculum was produced and support to schools in Afghanistan extended. In June 1989, AEC supported 77 projects representing a total of 484 schools; the number of students was 82,000 . A teacher training program is being carried out, and a pilot program, which started during the spring of 1989 , is to employ education coordinators for certain larger projects.

Funding: Swedish Government, UN agencies (mainly UNDP, UNHCR, and UNICEF contribute about 20\%), British and Canadian Governments.

Note: The Pakistan budget includes administrative overhead of Rs. 14.5 mil. in '87, Rs.21.4 mil. in '88, Rs. 34.00 mil. in ' 89 , and Rs.46.2 mil in 1990. 
LOCAL ADDRESS

P O BOX 967

UNIV TOWN PESHAWAR, PAK

34 F/A K K KHATTAK ROAD

UNIV TOWN PESHAWAR, PAK

TEL: $44536-42492$

TLX: 52399 USAID PK

FAX :

MR. G. R. BOARDMAN

MR. MOQIM RAHMANZAI
GENERAL

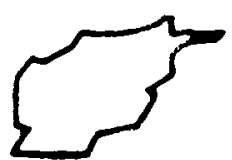

20

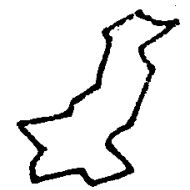

SECTOR

MR. TOM GOUTTIERRE

OFFICE OF INT'L STUDIES

UNIV OF NEB OMAHA, NE 68182-0013 USA TEL: 4025516292

TLX:

FAX:

\begin{tabular}{|lrr|}
\hline \multicolumn{3}{|c|}{ PERSONNEL } \\
EXPATS & 4 & $0 \%$ \\
AFGHANS & 6000 & $99 \%$ \\
PAKISTANIS & 1 & $0 \%$ \\
TOTAL & 6005 & \\
\hline
\end{tabular}

\section{FUNDERS}

GOVT

BUDGET (US \$) 1987

AFGHANISTAN $1,157,407$

PAKISTAN

TOTAL
1988

$3,329,633$

$3,329,633$
1989

$5,582,761$ 293,829

$5,876,590$
1990

$6,077,606$

467,508

$6,545,114$ 
The UNIVERSITY OF NEBRASKA (UNO) at Omaha is the technical assistance contractor for the Education Sector Support Project. UNO has a long history of interest in and support for the Afghan cause: it opened the Center for Afghanistan Studies in 1972, organized the Higher Education Project at Kabul University from 1974 to 1978 , was primary implementor in the Atlas of Afghanistan and the Dari-English Dictionary Projects, and currently implements Afghan Participant Training.

Project implementation began in October 1986, with its object being to provide educational and humanitarian assistance to Afghan citizens in the resistance. The primary focus has been on the controlled areas inside Afghanistan and - to a more limited degree - refugees who will be returning to Afghanistan.

The main accomplishments of the project include establishing an Educational Center for Afghanistan which is assisted by the UNO team and representatives of the Alliance and AIG. The University of Nebraska (Omaha) has been responsible for: the distribution of more than one million textbooks for primary schools inside Afghanistan and 400,000 to schools in refugee camps, the distribution of 9,000 sets of instructional materials and 14,000 mine awareness packets. Additionally, UNO has provided literacy training to 30,000 Mujahideen in their winter camps near Peshawar and Quetta, trained district supervisors of primary schools in Afghanistan, provided English language training for Afghan Participant Training in the U.S., and Manpower Training for clerical/administrative skills and tradeconstruction skills.

Future plans include the development of textbooks, more administrative and teacher training for district directors, and primary school teacher-training programs for implementation in liberated areas. Literacy training of Mujahideen will be further improved and will extend into the villages of Afghanistan. The design and development of narcotics awareness materials is in process.
Funding: USAID/REP. 
LOCAL ADDRESS

WHITE HOUSE 2 PARK LANE

UNIV. TOWN PESHAWAR, PAK

TEL: $42320-42352$

TXL: 52490 WHOUS PK

FAX: 42461

DR. JEAN FRANCOIS RUBIN

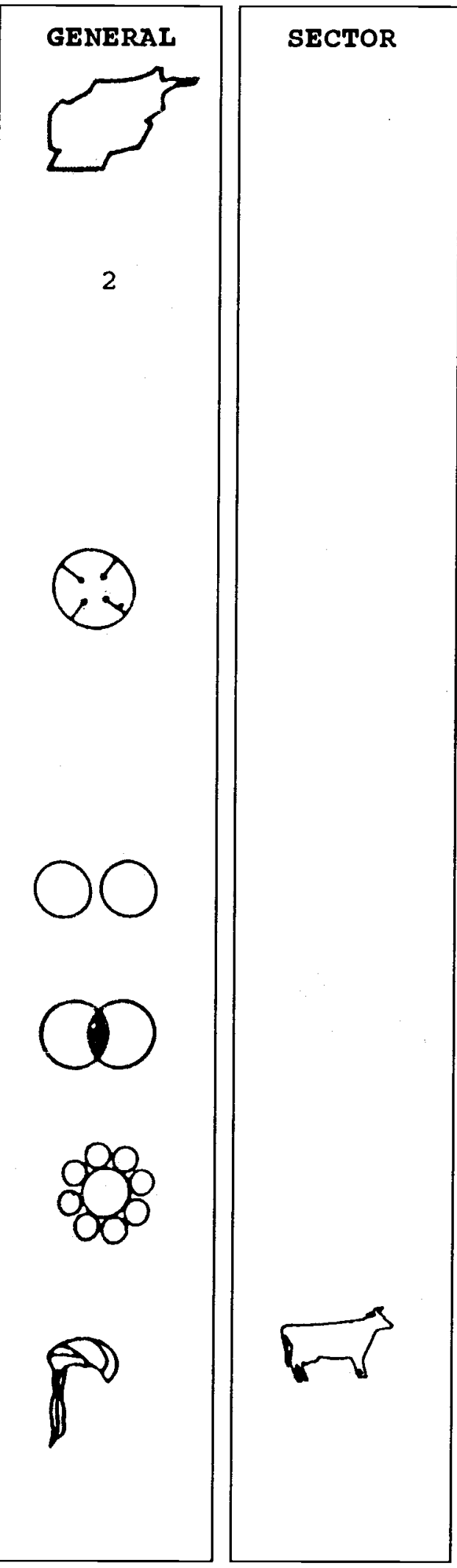

HEADQUARTERS

DR. JEAN FRANCOIS CAUTAIN

12, RUE MULET

69001 LYON FRANCE

TEL: $\begin{array}{llll}78 & 27 & 77 & 76\end{array}$

TXL: CECOMEX 310828

FAX:

\begin{tabular}{|lrr|}
\hline \multicolumn{3}{|c|}{ PERSONNEL } \\
EXPATS & 8 & $25 \%$ \\
AFGHANS & 20 & $62 \%$ \\
PAKISTANIS & 4 & $13 \%$ \\
TOTAL & 32 & \\
\hline
\end{tabular}

FUNDERS

UN

GOVT

PRIV
1990

514,258

514,258
AFGHANISTAN

PAKISTAN

TOTAL

1987
104,166
104,166

1988

199,778

199,778
1989

244,857

244,857

r

is

$\boldsymbol{c}$ 


\section{VETERINAIRES SANS FRONTIERES}

(VSF), a France-based organization, was created in late 1983, with the motto: "to safeguard animals, as elements of survival, a means to development and nutritional self-reliance." VSF has developed projects wherever populations may need assistance in the areas of animal husbandry, disease control, and management of fodder resources and pastures. VSF has worked in Guatemala, Mali, Niger, Ethiopia, Nepal. An office based in Peshawar coordinates activities in Afghanistan and Pakistan.

A professional staff of livestock and veterinary specialists provides technical assistance through both training and consultation in the contexts of short-term emergency situations and in long-term extension programs, in the implementation of its own projects and as consultants to other agencies.

In Pakistan, a survey is being carried out in Gilgit and Chitral Valley, and three project proposals will be implemented in 1990. In Afghanistan, VSF has a project in Wardak Province that has been operational since 1986. In 1989, extensions began in Badakhshan Province. VSF also participates in a MADERA program in Kunar through one of its expatriate staff members.

Funding: French Government, European Community, Afghanaid and UNDP. 
LOCAL ADDRESS

P.O.BOX 939

UNIV. TOWN PESHAWAR, PAK

3-B-1 CIRCULAR LANE

UNIV. TOWN PESHAWAR, PAK

TEL: $44518 / 42979$

TXL: 52491 VITA PK

FAX:

MR. M. M. A. SEDIQ

MR. R. MAC MAKIN

MR. A. THEISEN
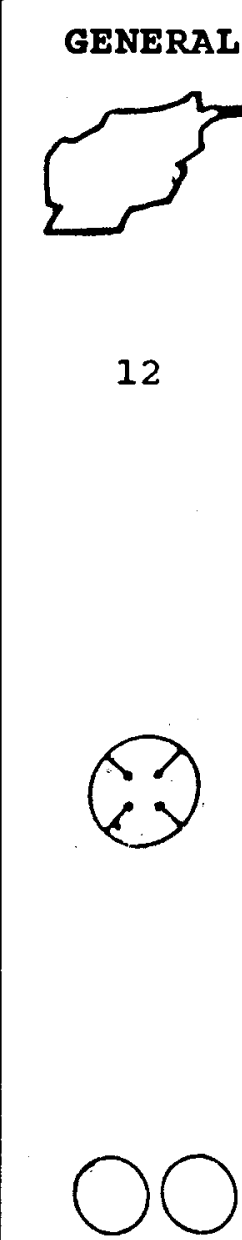

SUITE 200 ARLINGTON, VA 22209, USA

TEL: $703 \quad 276 \quad 1800$

TXI: 440192 VITAVI

FAX: $703 \quad 243 \quad 1865$

\begin{tabular}{|lrr|}
\hline \multicolumn{3}{|c|}{ PERSONNEL } \\
EXPATS & 4 & $1 \%$ \\
AFGHANS & 267 & $94 \%$ \\
PAKISTANIS & 15 & $5 \%$ \\
TOTAL & 286 & \\
\hline
\end{tabular}

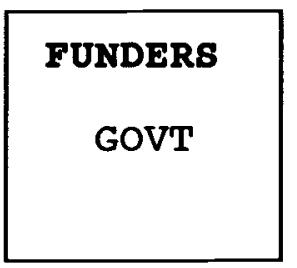

12

SECTOR

s.

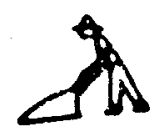

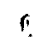

$$
6
$$
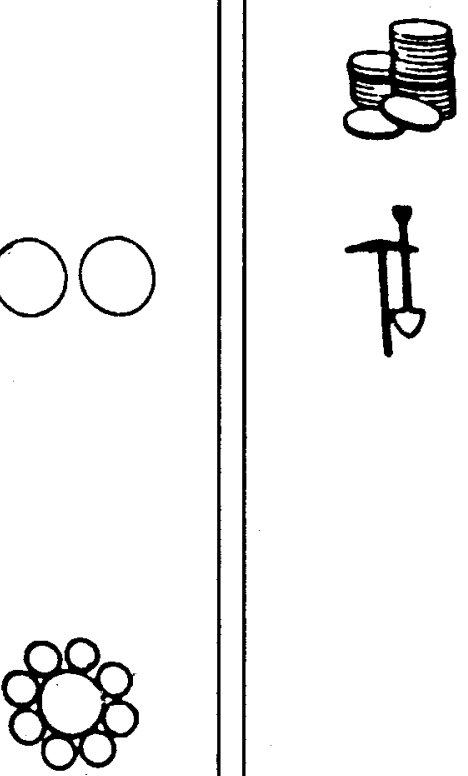

\section{8}

$11,547,347$

AFGHANISTAN

PAKISTAN

TOTAL 
VOLUNTEERS IN TECHNICAL ASSISTANCE (VITA) is a private, nonprofit, voluntary organization, funded by the U.S. Government. Its headquarters are in Virginia in the US and is locally based in Peshawar. It is primarily organized to help Afghanistan in the field of agriculture. This aim is pursued by providing resources to support increased agricultural productivity inside Afghanistan and to support the growth of institutional mechanisms to use these resources. The focus of VITA is strictly on helping the Afghan farmer inside Afghanistan.

Because of the war, fruit orchards were extensively damaged. VITA initiated the rehabilitation of these orchards by sending in about 2,700 rootstock of apple, peach and almond to seven of the eastern provinces of Afghanistan. As a part of its reforestation program, a total of 551,000 root cuttings of poplar and mulberry were sent to four provinces. VITA is currently working in 14 Agricultural Rehabilitation Schemes (ARSs) in the south-western and eastern provinces of Afghanistan. Its ARSs are located in the provinces of Kandahar, Ghazni, Wardak, Paktia, Baghlan, Logar, Parwan, Takhar and Kunar. Road work and rehabilitation of irrigation canals is underway in Paktia, Kunar, Logar, Kandahar, Parwan, Takhar, Ghazni, Baghlan and Nangarhar provinces.

VITA has so far sent, by various means, the following supplies/equipment into Afghanistan:

1. 300 wheat threshers and 200 rice huskers;

2. 1,800 water pumps;

3. $\quad 15$ tractors and implements and $\$ 300,000$ of spare parts;

4. Over 500 bullocks;

5. Seed and fertilizer for 1,000 farmers; VITA is planning to send 35 tons of improved wheat seed and 9,000 tons of fertilizer.
In the field of horticulture and agroforestry, VITA has established two nurseries in Pakistan for improved horticultural stock to replace that destroyed during the war. VITA is also contracting with farmers to grow 2 million seedlings.

In the rural works sector, VITA has received requests for 22,784 irrigation projects. Of these, 421 projects, mostly karezes and irrigation canals, have been rehabilitated; work on an additional 1,449 is in progress. Fifteen requests for roads -a total length of $30,930 \mathrm{kms}-$-have been received; work on $400 \mathrm{kms}$ of road has started, out of which $260 \mathrm{kms}$ has been completed.

In addition to the above, VITA is conducting training programs, of up to three months, for technicians and managers. The method of working is through local shuras in each ARS to ensure allocation of project resources in line with local priorities, and the emphasis is on user fees rather than free distribution.
Funding: US Government. 

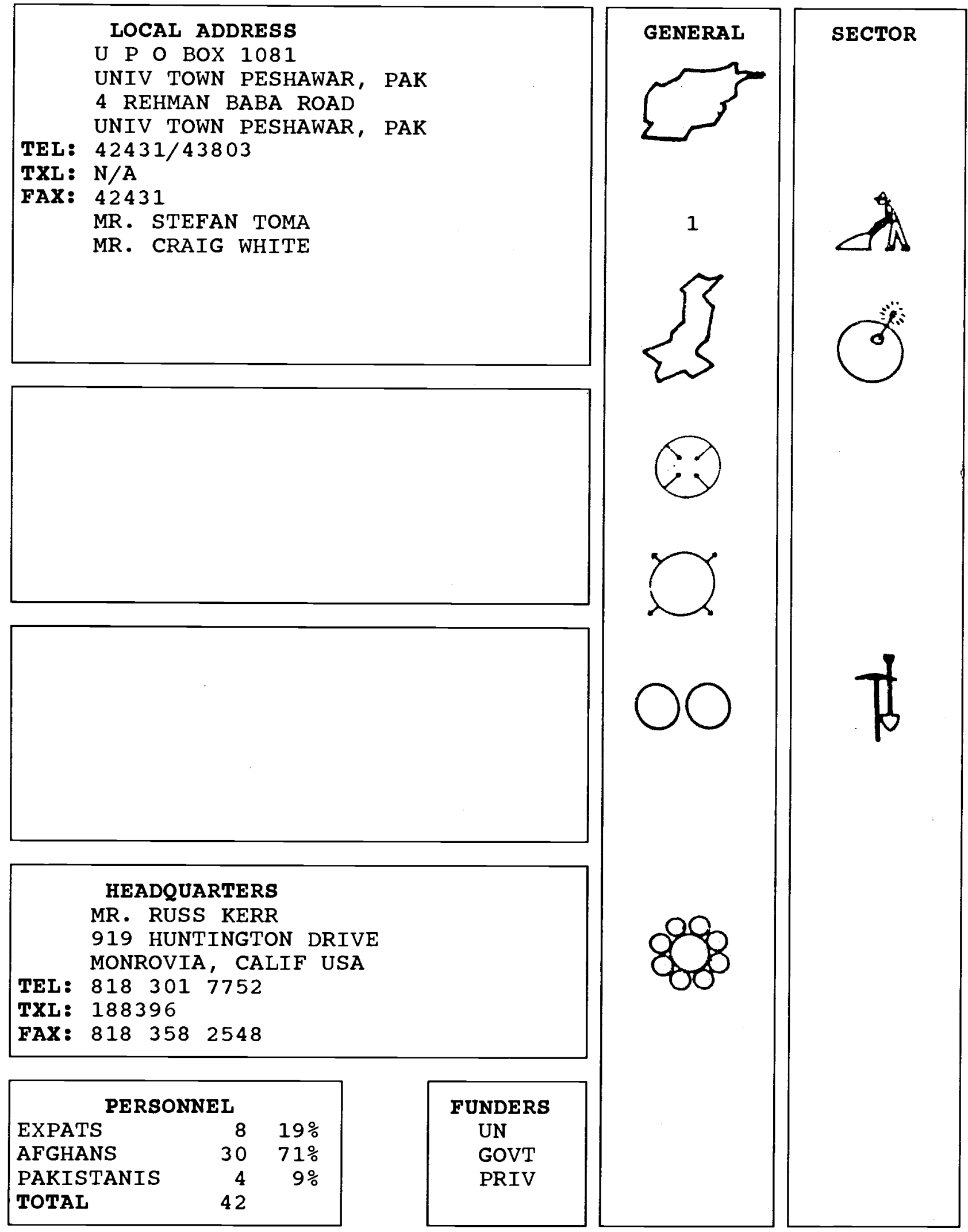

HEADQUARTERS

MR. RUSS KERR

919 HUNTINGTON DRIVE

MONROVIA, CALIF USA

TEL: $818 \quad 301 \quad 7752$

TXL: 188396

FAX: $818 \quad 358 \quad 2548$

\begin{tabular}{|lrr|}
\hline \multicolumn{3}{|c|}{ PERSONNEL } \\
EXPATS & 8 & $19 \%$ \\
AFGHANS & 30 & $71 \%$ \\
PAKISTANIS & 4 & $9 \%$ \\
TOTAL & 42 & \\
\hline
\end{tabular}

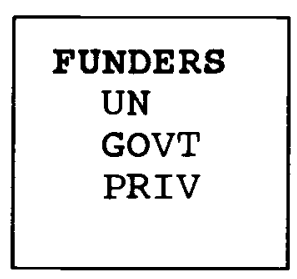

\begin{tabular}{|c|c|c|c|c|}
\hline $\begin{array}{l}\text { BUDGET (US \$) } \\
\text { AFGHANISTAN } \\
\text { PAKISTAN } \\
\text { TOTAL }\end{array}$ & 1987 & 1988 & $\begin{array}{c}1989 \\
470,000 \\
230,000 \\
700,000\end{array}$ & $\begin{array}{l}1990 \\
600,000 \\
300,000 \\
900,000\end{array}$ \\
\hline
\end{tabular}


WORLD VISION (WV) is a non-profit humanitarian organization, founded in 1948 to give relief aid to Korea. Today WV works in over 80 countries. Projects differ from country to country depending on local needs. World Vision generally implements its own projects; however, it occasionally funds projects of other agencies.

Since early 1989, the World Vision Afghan Rehabilitation Program has been working in the Chamkani Valley in Paktia province. We have projects in irrigation and agriculture plus a mine-clearing team that is helping to make the area safe for the local residents. We work directly with the local shura from whom we receive much of our direction.

The agricultural sector focused initially on making available a number of farm inputs including seeds, fertilizers and farm chemicals. All of the families living in the project area have been identified and WV is able to distribute seed to all of them within 10 days. The program will concentrate on improving the quality of seed available, particularly wheat and rice. More backpack sprayers and herbicides are being provided to assist farmers in overcoming their labor shortages. The introduction of a bee-keeping component is planned for the spring of 1990 . Three thousand fruit trees were planted in 1989; this number should be greatly expanded in the coming year.

In Chamkani the irrigation program concentrated on rehabilitation and repair of the irrigation structures, damaged either by bombing or by neglect during the last ten years. Repair work has been largely concentrated on Karezes, irrigation channels, culverts and water storage tanks. Much agricultural production is lost due to erosion by flooding of rivers and gullies; therefore, siphons with more durable structures are being installed to replace traditional aqueducts. Gabions are being placed to protect those gullies and river banks most at risk. Gabions are produced by local people trained by WV, using galvanized wire provided by WV. Concrete slabs and other reinforced structures are also produced locally.

World Vision also has a de-mining expert working in the Valley. He has trained and directed a small team in mine awareness and de-mining processes. To date over 600 mines have been defused and properly disposed of.
Funding: World Vision's support offices, UN-Agencies and various governmental organizations. 
ACBAR/SWABAC 

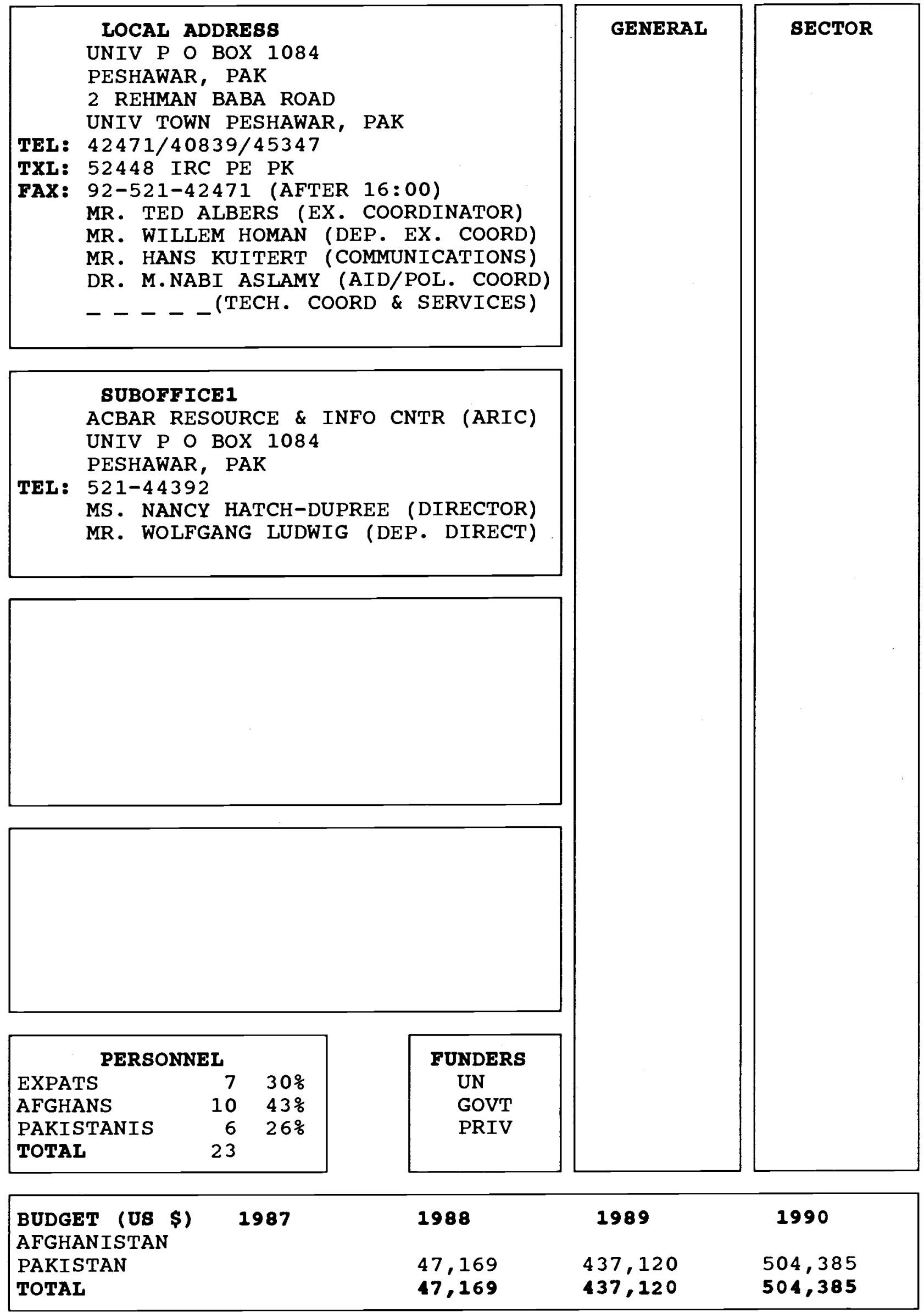

\section{SUBOFFICE 1}

ACBAR RESOURCE \& INFO CNTR (ARIC) UNIV P O BOX 1084 PESHAWAR, PAK

TEL： 521-44392

MS . NANCY HATCH-DUPREE (DIRECTOR)

MR. WOLFGANG LUDWIG (DEP. DIRECT)

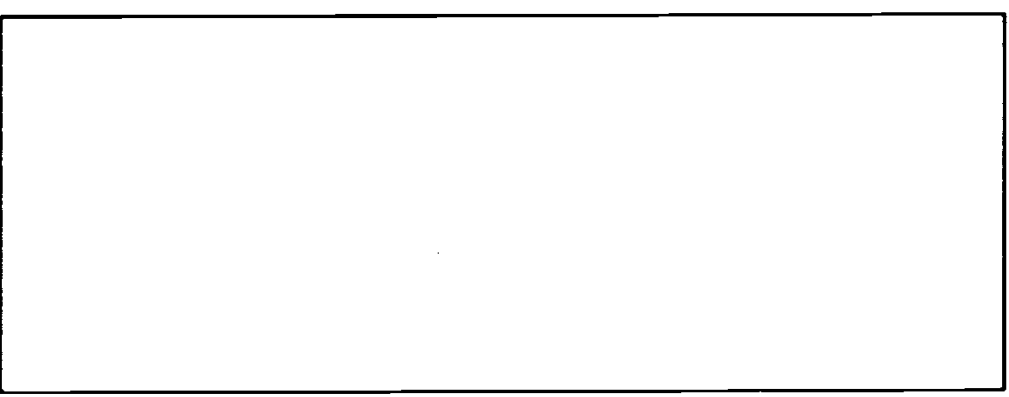

\begin{tabular}{|lrr|}
\hline \multicolumn{3}{|c|}{ PERSONNEL } \\
EXPATS & 7 & $30 \%$ \\
AFGHANS & 10 & $43 \%$ \\
PAKISTANIS & 6 & $26 \%$ \\
TOTAL & 23 & \\
\hline
\end{tabular}

FUNDERS
UN
GOVT
PRIV

BUDGET (US \$) 1987
AFGHANISTAN
PAKISTAN
TOTAL


The AGENCY COORDINATING BODY
FOR AFGHAN RELIEF (ACBAR) was founded in July 1988, shortly after the signing of the Geneva Accords. It currently comprises a membership of 58 non-governmental organizations (NGOs). The purpose of ACBAR is to provide the framework within which agencies and organizations providing assistance to Afghanistan - NGOs, UN, bilateral - can exchange information, share expertise and otherwise provide the mutual support that allows a more coordinated, efficient and effective use of the precious resources of assistance.

The primary organizational elements of ACBAR are the General Assembly, the Steering Committee and the Secretariat:

The General Assembly consists of member directors who set the overall policy of ACBAR and elect the Steering Committee.

The Steering Committee is composed of nine members - each an NGO director. With the overall guidance of the General Assembly, the Committee determines the operational policy of ACBAR.

The Secretariat is responsible for executing the decisions and directives of the Steering Committee and for initiating policy- and donor-related activities on behalf of the ACBAR membership.

During 1989, the first full year of operation, activity - generated by the expressed needs of the membership and input of the wider aid community - began to coalesce into four distinct categories of organizational objectives. These four areas have emerged as the basis for ACBAR's work for the 1990-91 planning period: 1) Aid and Policy Coordination; 2) Technical Coordination and Services; 3) Information Flow; and, 4) External Relations.
Aid and Policy Coordination.

ACBAR provides a forum for NGOs to share information about their activities in Afghanistan through the Aid and Policy Coordination Department. The primary tools used in this process are the regional coordination meetings, the Database of NGO Programs in Afghanistan and Pakistan, and the Agriculture and Health Subcommittees. The information, currently available, is used at the preventive rather than planning level to: avoid program duplication; approach current problems in implementation; set basic standards and guidelines for sectoral activities; and discuss technical issues regarding the delivery of aid.

\section{Technical Coordination and Services.}

A new department in ACBAR which will coordinate suppliers of technical support and training in the aid community, and provide consultancy advice to NGOs in need of organizational planning and financial management and administrative training. The Department will provide "soft" technical support to a limited number of NGOs in need of assistance and will register and coordinate those "hard" technical training resources already available in the community, i.e., specific technical expertise in the fields of agronomics, logistics, engineering, veterinary science, health, and so forth.

\section{Information Flow.}

Information flow as an area of work facilitates the general climate for coordination. The information function is to assist other ACBAR departments and their activities and to produce a variety of resource materials which relate to the information needs of the NGO 
community. This department coordinates its activities closely with those of the ACBAR Resource and Information Center (ARIC).

\section{External Relations.}

The goal of External Relations is to promote a positive climate of opinion on Afghanistan and the NGO role in assistance, through increased press activities and donor contact. Its purpuse, too, is to build an effective working relationship among ACBAR members, and the Afghan Interim Government, the Government of Pakistan and UN agencies so that aid to Afghanistan is provided and distributed with the maximum efficiency.

Funding: UNDP, governments of Canada, Norway, the Netherlands, Australia, Denmark, United Kingdom, Sweden. Membership dues. The Asia Foundation for support to the ACBAR Resource and Information Center.
The ACBAR RESOURCE AND INFORMATION CENTER (ARIC) is a semi-autonomous body within ACBAR, created in April 1989, to provide a centralized location for collecting, organizing and disseminating information on NGO, bilateral and multilateral refugee assistance and cross-border programmes for the Afghan people.

The services of ARIC to the community include:

A. Collection and organization of resource materials appropriate to the needs of the assistance community, including maps, books and journals, articles, field reports, bibliographies, and references;

B. Dissemination of information regarding ARIC's services, current holdings and activities through a News Bulletin and other appropriate media techniques;

C. Provision of a cartographic service to encourage balanced regional planning;

D. Provision of microfiche service;

E. The establishing of institutional linkages with various sources of information (i.e., study centers, and research units), specializing in refugee affairs and/or Afghan studies, within Peshawar and abroad;

F. Setting up channels between the several databases already existing so as to institutionalize access;

G. Organization of meetings, conferences, workshops, seminars and lecture programs utilizing resident and visiting scholars and field personnel within the NGO, 
bilateral and multilateral communities;

H. Collaboration with the ACBAR Communication Department in translating selected materials on request in French, Bari, Pashto and possibly Arabic - so as to strengthen the participation of nonEnglish speaking NGO staff in decision- making processes;

I. Assistance to ACBAR and its specific sub-committees in the formulation and distribution of standards, guidelines, reports and recommendations;

J. And, because the scarcity of skilled Afghans for Peshawar-based and cross-border programs is of increasing concern, incorporation of a training component, including training and information workshops, to increase Afghan involvement in decision-making and programming on all key levels. 
LOCAL ADDRESS

$30 A$ CHAMAN HOUSING SCHEME QUETTA PAKISTAN

$30 A$ CHAMAN HOUSING SCHEME QUETTA PAKISTAN

TEL: (081) 77005

TXL: 7840 UNHCR PK

FAX:

MR. PAUL FISHTEIN

MS . JOSE DE CLERCQ
SECTOR

9

(1)

r

$i$

1

\begin{tabular}{|lrr|}
\hline \multicolumn{3}{|c|}{ PERSONNEL } \\
EXPATS & 2 & $66 \%$ \\
AFGHANS & 0 & $0 \%$ \\
PAKISTANIS & 1 & $33 \%$ \\
TOTAL & 3 & \\
\hline
\end{tabular}

BUDGET (US \$)

AFGHANISTAN

PAKISTAN

TOTAL 


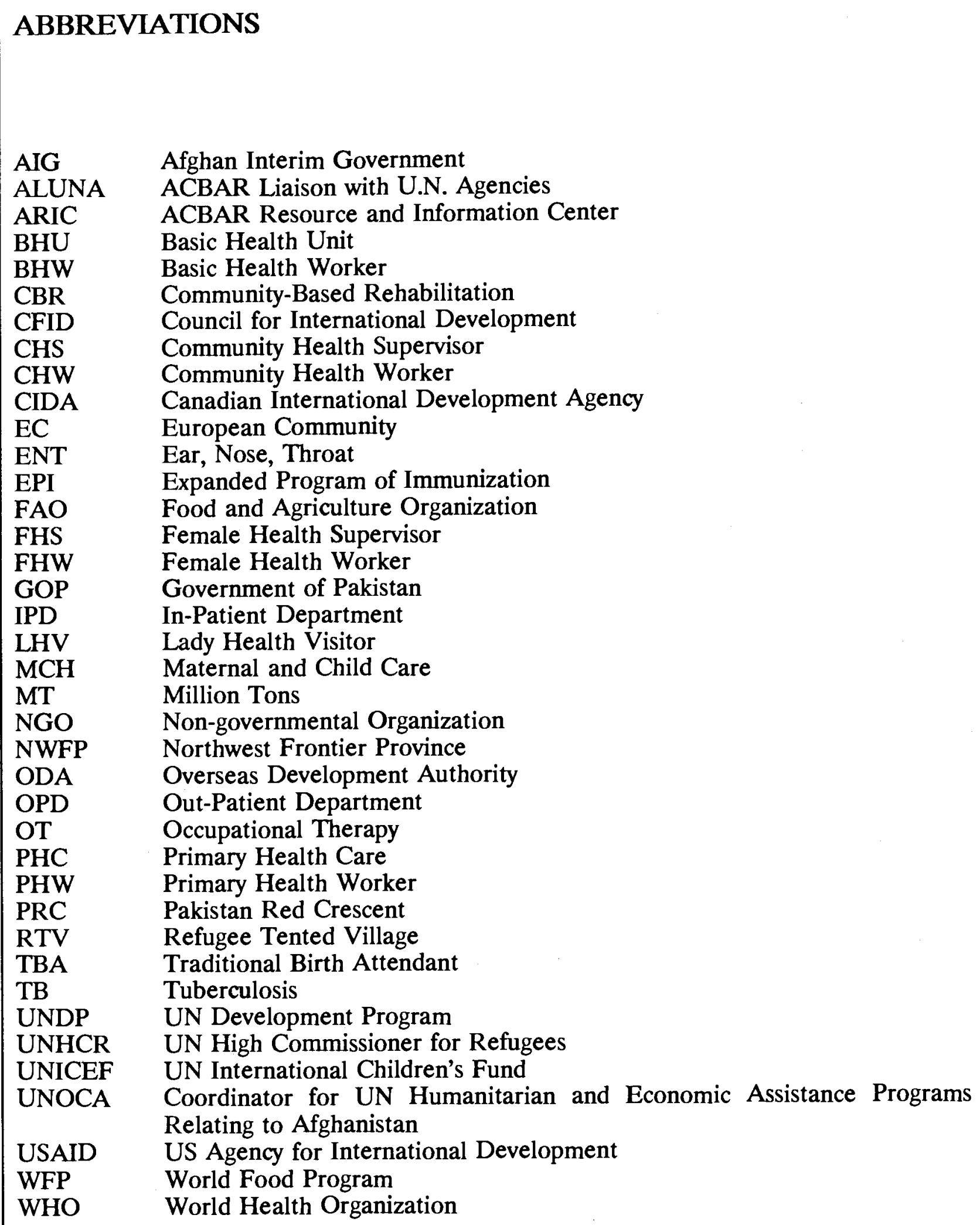


